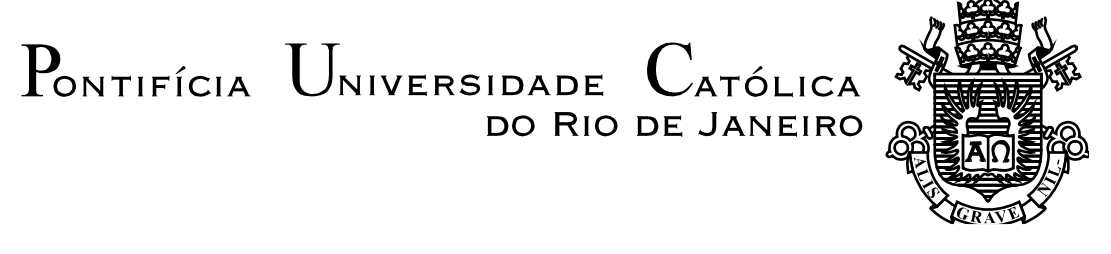

Felipe Duarte Pinheiro

\title{
"Porque elas aparentam ser meninas ou agem como meninas": apagamento de identidades não-binárias em traduções do mangá Houseki no Kuni
}

Dissertação de Mestrado

Dissertação apresentada como requisito parcial para obtenção do título de Mestre em Letras/Estudos da Linguagem pelo Programa de Pós-graduação em Estudos da Linguagem, do Departamento de Letras da PUC-Rio.

Orientador: Prof. Paulo Henriques Britto

Rio de Janeiro

Fevereiro de 2021 


\title{
Pontifícia Universidade Católica $_{\text {a }}$ \\ DO RIO DE JANEIRO

Felipe Duarte Pinheiro

\begin{abstract}
"Porque elas aparentam ser meninas ou agem como meninas": apagamento de identidades não-binárias em traduções do mangá Houseki no kuni
\end{abstract}

Dissertação apresentada como requisito parcial para obtenção do grau de Mestre pelo Programa de Pós-graduação em Estudos da Linguagem da PUC-Rio. Aprovada pela Comissão Examinadora abaixo:

Prof. Paulo Fernando Henriques Britto

Orientador

Departamento de Letras - PUC-Rio

Prof. Marcia do Amaral Peixoto Martins Departamento de Letras - PUC-Rio

Prof. Elizabeth Sara Lewis

UNIRIO

Rio de Janeiro, 22 de fevereiro de 2021. 
Todos os direitos reservados. A reprodução, total ou parcial, do trabalho é proibida sem autorização do autor, do orientador e da universidade.

\section{Felipe Duarte Pinheiro}

Graduou-se em Letras - licenciatura: língua portuguesa e literaturas de lusófonas pela Universidade Federal do Estado do Rio de Janeiro (UNIRIO). Durante a graduação, foi bolsista pibid/CAPES. Tem experiência na área de Letras e estudos da linguagem, com ênfase em língua portuguesa, literatura, Estudos da Tradução e Teoria Queer.

Ficha Catalográfica

Pinheiro, Felipe Duarte

"Porque elas aparentam ser meninas ou agem como meninas" : apagamento de identidades não binárias em traduções do mangá Houseki no Kuni / Felipe Duarte Pinheiro ; orientador: Paulo Henriques Britto. - 2021. 102 f. : il. color. ; $30 \mathrm{~cm}$

Dissertação (mestrado)-Pontifícia Universidade Católica do Rio de Janeiro, Departamento de Letras, 2021. Inclui bibliografia

1. Letras - Teses. 2. Tradução. 3. Tradução queer. 4. Gênero e sexualidade. 5 . Ideologias. 6. Cisheteronormatividade. I. Britto, Paulo Henriques. II. Pontifícia Universidade Católica do Rio de Janeiro. Departamento de Letras. III. Título. 
Dedicado à memória de meu pai, Alvaro Celso Pinheiro 


\section{Agradecimentos}

Gostaria de agradecer...

... ao meu orientador, dr. Paulo Henriques Britto, por ter aceitado orientar minha pesquisa, apesar de o seu tema não se enquadrar no tipo de pesquisa que geralmente orienta, e pelos seus comentários.

... à minha mãe, Mônica Moreira Duarte Pinheiro, pelo apoio incondicional e incentivo que me deu ao longo de todos esses anos, e por acreditar em mim quando precisei mudar o rumo da minha vida.

... aos meus irmãos, Alvaro, Rodrigo e Ana Carolina, por estarem sempre ao meu lado, mesmo quando distantes, e por fazerem da minha vida tão feliz. Não sei o que seria dela sem vocês.

... axs professorxs do PPGEL, cujos ensinamentos estão presentes nas páginas da presente pesquisa.

... axs colegas que me acompanharam durante o mestrado. Nossas discussões me ajudaram a moldar esta pesquisa e a pensar no tema do meu doutorado.

... à professora dra. Marcia do Amaral Peixoto Martins por aceitar compor a minha banca.

... axs professores dr. Rodrigo Borba e dra. Teresa Dias Carneiro por terem aceitado o convite para suplência na banca examinadora.

... à agência de fomento CNPq, pela bolsa concedida sem a qual a presente pesquisa não seria possível. 
... O presente trabalho foi realizado com apoio da Coordenação de Aperfeiçoamento de Pessoal de Nível Superior - Brasil (CAPES) - Código de Financiamento 001.

... por fim, à professora doutora e diva Elizabeth Sara Lewis, por ter aceitado compor a banca examinadora, por ter despertado a minha paixão pela pesquisa acadêmica, por ter-me "empurrado" para uma pós-graduação, pelo apoio, criticas, sugestões, por ter-me apresentado à Teoria Queer e aos Estudos da Tradução, sem os quais essa pesquisa não seria possível, pela paciência para revisar os meus trabalhos e o meu projeto de doutorado, por me viciar na diversão brega que é Star Trek (embora, parando para pensar agora, isso pode ter sido um ato perverso de sabotagem acadêmica). Mas, acima de tudo, por ser esse exemplo inspirador e maravilhoso de ser humano. Sempre que estou deprimido e me vejo sem esperanças para o futuro, eu me lembro de você e penso que, se pessoas assim existem, a Federação não é um sonho impossível...

... Vida longa e próspera _ $\ / / \ldots$ 


\section{Resumo}

Pinheiro, Felipe Duarte; Britto, Paulo Henriques (orientador). "Porque elas aparentam ser meninas ou agem como meninas": apagamento de identidades não-binárias em traduções do mangá Houseki no kuni. Rio de Janeiro, 2021. 102p. Dissertação de mestrado - Departamento de Letras, Pontifícia Universidade Católica do Rio de Janeiro.

A pesquisa intitulada "Porque elas aparentam ser meninas ou agem como meninas': apagamento de identidades não-binárias em traduções do mangá Houseki no kuni" analisa cinco traduções do referido mangá - duas traduções profissionais, uma para o inglês e uma para o francês; e três traduções amadoras, uma para o português, uma para o espanhol e uma para o inglês - e como essas lidaram com a não-binariedade dxs personagens. $\mathrm{O}$ objetivo foi examinar as maneiras nas quais ideologias hegemônicas de tradução e cis-heteronormativas podem levar ao apagamento de identidades LGBTQAI+. A análise dos dados demonstrou que todas as traduções para línguas neolatinas, assim como a tradução amadora para o inglês designaram um gênero axs personagens. No caso das línguas neolatinas, a análise dos meta e paratextos sugerem que o gênero gramatical dessas línguas desempenhou um papel importante no apagamento da não-binariedade de gênero. Contudo, também se verificou evidências da influência de ideologias cisheteronormativas na escolha das estratégias tradutórias empregadas. Dentre as traduções analisadas, apenas a tradução profissional para o inglês não designou um gênero axs personagens. Contudo, a análise de fontes metatextuais revelou que ideologias de tradução relacionadas à ideia de "fluência" estavam por trás das estratégias tradutórias utilizadas, resultando em uma tradução que mantém a nãobinariedade, porém, não a visibiliza. Ao estudar as ideologias cis-heteronormativas e de tradução que subjazem às estratégias tradutórias empregadas, a presente pesquisa contribui para entender como identidades LGBTQAI+ podem ser facilmente apagadas em traduções e propor formas de visibilizá-las a fim de combater a hegemonia cis-heteronormativa. 


\section{Palavras-chave:}

tradução; tradução queer; gênero e sexualidade; ideologias; cisheteronormatividade 


\section{Abstract}

Pinheiro, Felipe Duarte; Britto, Paulo Henriques (advisor). "Because they look like girls or act like girls": erasure of non-binary identities in translations of the Houseki no kuni manga. Rio de Janeiro, 2021. 102p. Master's dissertation - Departmento de Letras, Pontifícia Universidade Católica do Rio de Janeiro.

The research entitled ''Because they look like girls or act like girls': erasure of non-binary identities in translations of the Houseki no kuni manga" analyzes five translations of the referred manga - two professional translations, one into English and one into French ; and three amateur translations, one into Portuguese, one into Spanish and one into English - and how they dealt with the non-binary gender of the characters. The objective was to examine the ways in which cis-heteronormative ideologies and hegemonic translation ideologies can lead to the erasure of LGBTQAI + identities. The analysis of the data showed that all the translations to Neo-Latin languages, as well as the amateur translation into English designated a gender to the characters. In the case of Neo-Latin languages, the analysis of meta and paratexts suggests that the grammatical gender of these languages played an important role in erasing the non-binary gender of the characters. However, there was also evidence of the influence of cis-heteronormative ideologies in the choice of translation strategies employed. Among the translations analyzed, only the professional translation into English did not designate a gender to the characters. However, the analysis of metatextual sources revealed that translation ideologies related to the idea of "fluency" were behind the translation strategies used, resulting in a translation that maintains the non-binary gender of the characters, but does not make it visible. By studying the cis-heteronormative and translation ideologies that underlie the translation strategies employed, this research contributes to understand how LGBTQAI + identities can be easily erased in translations and propose ways to make them visible in order to fight cis-heteronormative hegemony. 


\section{Keywords:}

Translation; queer translation; gender and sexuality; ideologies; cisheteronormativity 


\section{Sumário}

1. Introdução 13

1.1 Dados e abordagens 15

1.2 Perguntas de pesquisa e objetivos 18

$\begin{array}{ll}1.3 \text { Justificativa e relevância } & 19\end{array}$

1.4 Gênero e sexualidade nos mangás 22

1.5 Houseki no kuni 26

1.6 Organização da dissertação 29

2. Visibilização como resistência: da Invisibilidade do Tradutor à Tradução Queer

2.1 A Invisibilidade do Tradutor 31

2.2 Tradução feminista 36

2.3 Tradução Queer 41

2.3.1 A matriz cis-heteronormativa 42

2.3.2 Implicações da matriz cis-heteronormativa para a tradução $\quad 47$

2.3.3 Tradução Queer e a possibilidade de mudança na matriz cis-heteronormativa $\quad 50$

3. Análise 56

3.1 Tradução amadora para o português 56

3.2 Traduções amadoras para o inglês e o espanhol 68

3.2.1 Tradução amadora para o inglês 68

3.2.2 Tradução amadora para o espanhol $\quad 74$

3.3 Tradução profissional para o francês 80

3.4 Tradução profissional para o inglês 82

4. Considerações finais 90

$\begin{array}{lr}\text { 5. Referências bibliográficas } & 97\end{array}$ 


\section{Lista de figuras}

Figura 1: torso e rosto dxs personagens 28

Figura 2: nota da tradutora (SAMORO, 2019b, p.1) 57

Figura 3: fragmento de cena do capítulo 2 (ICHIKAWA, 2017b, p.3) 64

Figura 4: uso do masculino para se referir ax personagem Cairngorm (ICHIKAWA, 2018, p.21)

Figura 5: uso do masculino genérico a partir do capítulo 80 (ICHIKAWA, 2020c, p.7)

Figura 6: nota dx tradutorx da tradução amadora para o inglês (ICHIKAWA, 2020a, p.1)

Figura 7: fragmento de cena do capítulo 2 (ICHIKAWA, 2020b, p.3) 71

Figura 8: exemplo de reforço do masculino (ICHIKAWA, 2020b, p.8) 72

Figura 9: exemplo do uso do pronome "they" no singular (ICHIKAWA, 2019, p.12)

Figura 10: notas da tradução amadora para o espanhol

Figura 11: fragmento de cena do capítulo 2 (ICHIKAWA, 2016c, p.4)

Figura 12: exemplo do uso de elipses para manter a referência neutra (ICHIKAWA, 2016c, p.8)

Figura 13: fragmento de cena do capítulo 2 (ICHIKAWA, 2016a, p.41) 81

Figura 14: nota das tradutoras (NIBLEY; NIBLEY, 2017, p.196)

Figura 15: fragmento de cena do capítulo 2 (ICHIKAWA, 2017a, p.41) 85

Figura 16: uso do masculino na tradução amadora para o inglês (ICHIKAWA, 2020b, p.7)

Figura 17: mudança nos sujeitos das orações para evitar o uso do masculino (ICHIKAWA, 2017a, p.45)

Figura 18: uso do discurso impessoal para evitar formas masculinas (ICHIKAWA, 2017a, p. 46) 


\title{
1. Introdução
}

A presente pesquisa examina as imbricações entre ideologia ${ }^{1}$ e tradução concentrando-se nas maneiras como ideologias cis-heteronormativas ${ }^{2}$ ou de tradução podem contribuir para o apagamento de identidades LGBTQAI+ em textos traduzidos. Em seu texto The ideological turn in Translation Studies (2006), Matthew Wing-Kwong Leung chama a atenção para uma virada ideológica nos Estudos da Tradução, a qual seria marcada pelo seu foco no significado ideológico do ato de traduzir. Todo sujeito encontra-se inserido em um contexto sóciohistórico-cultural e possui as suas próprias crenças e ideologias que irão, inevitavelmente, afetar sua maneira de ver o mundo. Logo, é de se esperar que o ato de traduzir esteja sujeito à influência das ideologias dxs tradutorxs ${ }^{3}$, ou das que orientam as normas que regem a prática tradutória em uma determinada cultura e em um determinado período, de modo que "a ideologia de uma tradução reside não apenas no texto traduzido, mas na voz e na postura dx tradutorx e em sua relevância para o público receptor" (TYMOCZKO, [2003] 2014, p.183) ${ }^{4}$.

Essa relação entre tradução e ideologia já foi amplamente explorada nos Estudos da Tradução, sendo notável, nesse sentido, o trabalho de André Lefevere. Para o autor,

\begin{abstract}
Dois fatores determinam basicamente a imagem de uma obra de literatura projetada por uma tradução. Esses dois fatores são, em ordem de importância, a ideologia do tradutor (se ele/ela a abraça de bom grado, ou se é imposta a ele/ela como uma restrição por alguma forma de patrocínio) e a poética dominante na literatura receptora no momento da tradução. A ideologia dita a estratégia básica que o tradutor vai usar e, portanto, também dita soluções para problemas relacionados tanto ao "universo do discurso" expressos no original (objetos, conceitos, costumes
\end{abstract}

\footnotetext{
${ }^{1} \mathrm{Na}$ presente pesquisa, trabalho com a concepção de ideologia como um conjunto de convicções filosóficas, sociais, políticas etc. de um indivíduo ou de uma sociedade que orientam as suas visões de mundo.

${ }^{2} \mathrm{O}$ conceito de cis-heteronormatividade será explicado na seção 2.3.1

${ }^{3}$ Para manter a coerência em um trabalho em que defendo a importância de manter-se a nãobinariedade do gênero nas traduções, optei pelo uso do " $x$ " como forma de não designar um gênero axs personagens. $O$ seu uso em palavras associadas a substantivos cujo gênero não varia de acordo com a entidade a qual se refere, como "personagem" e "gemas", é devido a questões pragmáticas para enfatizar o aspecto não-binário dxs personagens do mangá, pois como veremos no decorrer da presente pesquisa, elxs tendem a ser generificadxs por leituras enviesadas do texto. $O$ "x" também será utilizado como forma de evitar o uso do masculino genérico nos casos de palavras que se referem a indivíduos de forma generalizada ou pessoas cujo gênero não pôde ser identificado; isso inclui as traduções feitas por mim, exceto aquelas em que alguma forma de evitar o masculino genérico já tinha sido empregada no texto fonte. No caso das tradutoras feministas, utilizarei o feminino como forma de visibilizar essas mulheres.

${ }^{4}$ Todas as traduções são minhas, a menos que indicado o contrário.
} 
pertencentes ao mundo que era familiar ao escritor do original) quanto à linguagem na qual o original em si é expresso. (1992, p.41)

Para exemplificar o caráter ideológico das traduções, Lefevere cita o caso da tradução do poeta persa Omar Khayyam feita por Edward Fitzgerald, o qual, por considerar a poesia persa inferior à poesia inglesa vitoriana, tomava todo tipo de liberdades ao traduzi-la. Entretanto, o viés ideológico das traduções é melhor exposto em sua análise de diferentes traduções da peça Lisístrata, de Aristófanes, nas quais aponta que diferentes tradutorxs inseridxs em contextos sócio-históricos distintos, muitas vezes recusavam-se a fazer traduções "literais" da peça, por vezes omitindo ou atenuando passagens de teor abertamente sexual. Com esses exemplos, o autor evidencia que traduções manipulam os textos fonte para adequá-los às correntes ideológicas dominantes.

Santaemilia (2008) assinala que, na tradução de termos relacionados ao sexo - e eu acrescentaria também aqueles relacionados a gênero e sexualidade -, não está em jogo apenas o significado das expressões, mas também questões estéticas, culturais e ideológicas. Ao eliminar, atenuar ou intensificá-los na tradução, x tradutorx geralmente deixa entrever o seu posicionamento em relação a esses temas, de forma que estudar como são traduzidos pode nos fornecer um vislumbre das ideologias que subjazem aos valores morais de uma dada comunidade em um momento histórico específico.

Para Leung (2006) a principal contribuição dxs tradutorxs e teóricxs da tradução deve ser "[...] conscientizar a si mesmos e axs leitorxs da influência predominante da ideologia no discurso, e como xs tradutorxs devem lidar com essa realidade" (2006, p.134). Adotar esse posicionamento significa encorajar o olhar crítico dxs leitorxs através da exposição da natureza ideológica do texto fonte e de suas traduções. A tradução não teria como objetivo apenas melhorar a compreensão intercultural, mas também espalhar ideologias geralmente associadas a grupos historicamente excluídos, de maneira que se torne uma forma de resistência.

Adotando esse viés da tradução como resistência, a presente pesquisa tem como ponto de partida a Teoria da Invisibilidade do Tradutor (VENUTI 1995, [1998] 2019), segundo a qual traduções carregam um subtexto de caráter social, histórico e político, podendo ser utilizadas para reforçar relações de dominação e 
dependência, ou como instrumento de libertação, tanto a partir dos textos que se escolhe traduzir quanto pela forma como são traduzidos. Para tratar da relação entre tradução e questões de gênero e sexualidade especificamente, faço uso também da Tradução Queer (LEWIS, 2010), para a qual, devido à influência de ideologias cis-heteronormativas hegenônicas, identidades ${ }^{5}$ LGBTQAI+ tendem a ser apagadas em traduções seja por meio de censura direta, autocensuras ou por leituras descuidadas causadas por predisposições cis-heteronormativas; e que, por conta disso, é preciso que traduções deem visibilidade a essas identidades como forma de resistência.

Estudar como a imbricação entre ideologias cis-heteronormativas e ideologias sobre tradução e linguagem contribui para o apagamento dessas identidades pode nos ajudar a pensar em formas de tradução que as visibilizem e as ajudem a enfrentar a hegemonia cis-heteronormativa e a marginalização.

\subsection{Dados e abordagem}

Foram selecionadas para a presente pesquisa cinco diferentes traduções do mangá Houseki no kuni, de Haruko Ichikawa: duas traduções profissionais, uma para o inglês e uma para o francês; e três traduções amadoras, uma também para o inglês, uma para o espanhol e uma para o português. A escolha das traduções foi feita de forma a também levar em consideração como os obstáculos presentes na própria estrutura da língua, como a presença ou não de gênero gramatical, pode exercer um papel na forma como o mangá foi traduzido. No caso das traduções para o inglês, serão analisadas as maneiras como as traduções profissional e amadora para uma língua em que o gênero não é uma categoria sempre marcada divergiram em relação às formas de lidar com o gênero dxs personagens. Para as línguas inglesa e francesa, foram selecionadas as traduções profissionais publicadas pelas editoras Kodansha e Glénat, respectivamente. Já as traduções amadoras escolhidas para as línguas inglesa, espanhola e portuguesa foram as disponíveis nos sites https://manganelo.com/, http://es.ninemanga.com e https://dispersiontl.blogspot.com/, respectivamente.

\footnotetext{
${ }^{5}$ Dada a perspectiva queer com a qual trabalho na presente pesquisa, adoto a visão das identidades como dinâmicas e coconstruídas performativo-discursivamente na linguagem e nas interações, e não como expressões de alguma essência natural, inata e estável.
} 
A análise dos dados seguirá o modelo descritivo proposto por José Lambert e Hendrik Van Gorp. Em seu texto "Sobre a descrição de traduções" ([1985] 2011), os autores apontam que, até aquele momento, a importância dos estudos descritivos da tradução ainda não havia sido devidamente reconhecida pela teoria da tradução. Esse fenômeno é atribuído à desconexão que haveria entre a abordagem teórica e a abordagem descritiva na época, o que, por sua vez, devia-se ao fato de que os estudos descritivos da tradução não tinham uma metodologia de pesquisa estabelecida.

Segundo os autores, tradicionalmente a crítica da tradução apresentava um aspecto binário, onde o texto fonte e o texto traduzido eram confrontados e a pesquisa focava em verificar se certos aspectos linguísticos desse último são equivalentes aos do primeiro, o que frequentemente resultava em abordagens reducionistas. Para Lambert e Van Gorp, essa abordagem não é capaz de dar conta da complexidade da equivalência, pois nem sempre $\mathrm{x}$ tradutorx utiliza o texto fonte como modelo dominante, além de interferências do sistema alvo no processo de tradução serem inevitáveis. Contudo, ressaltam que ele também pode ser crucial em uma análise sistêmica, devido ao fato de que, frequentemente, texto fonte e texto meta são os únicos materiais disponíveis para estudo e, quando temos as estratégias tradutórias evidentes no próprio texto, isso pode ser uma valiosa fonte de informação sobre as relações entre o sistema fonte e o sistema meta.

Uma forma de escapar desse método reducionista seria adotar um quadro de referência para guiar tal comparação. Esse quadro não pode orientar-se apenas em relação ao texto fonte, utilizando-se, em vez disso, de categorias tiradas tanto do texto fonte quanto do texto meta e que podem ser enriquecidas a partir de questionamentos que surgem dos sistemas fonte e meta. Os autores, então, procuram apresentar um esquema metodológico abrangente que permita realizar pesquisas descritivas em tradução considerando os seus diferentes aspectos. Para isso, baseiam-se no esquema apresentado por Toury e Even-Zohar para a teoria dos polissistemas, que contém os parâmetros básicos envolvidos nos fenômenos tradutórios, sendo eles: texto, autorx e leitorx pertencentes ao sistema fonte, e texto, autorx e leitorx pertencentes ao sistema alvo. Para os autores, todas as maneiras como os elementos desse esquema se relacionam merecem ser estudadas; e eles apresentam alguns dos possíveis caminhos de pesquisa que podem surgir 
dele, organizados em quatro níveis conforme o modelo abaixo, que consta no apêndice do seu artigo:

- Dados preliminares: título e página título; metatextos (prefácio, notas de rodapé, ensaios, resenhas etc. sobre a obra); estratégia geral;

- Macronível: divisão do texto; título dos capítulos; estrutura geral da tradução;

- Micronível: escolhas de tradução relacionadas ao vocabulário, estruturas gramaticais, formais estilísticas etc.;

- Contexto sistêmico: as oposições entre os níveis macro e micro; relações entre textos naquele sistema; relações entre sistemas.

O método consiste basicamente em transitar entre esses diferentes níveis, com as análises dos dados de um nível servindo para formular hipóteses que guiarão a análise do nível seguinte. Assim, inicia-se por coletar informações macroestruturais gerais da tradução: sua identificação (tradução, adaptação, imitação); o significado desses termos no período determinado; se o nome $d x$ tradutorx aparece em algum lugar; se o texto pode ser reconhecido como um texto traduzido; se há algum paratexto $\mathrm{dx}$ tradutorx ou dx editorx; se a tradução é "domesticadora" ou "estrangeirizadora". Esse levantamento aponta possíveis estratégias tradutórias e o que priorizam. A partir dessa análise inicial, $\mathrm{x}$ pesquisadorx passaria para uma segunda fase, na qual seriam analisados outros fragmentos a fim de averiguar coisas como acréscimo ou exclusão de parágrafos, capítulos, palavras ou características literárias; se isso ocorre ao longo de todo o texto ou apenas em certos trechos; o que explicaria tais decisões etc. Na etapa seguinte, analisam-se coisas como vocabulário, estilo ou convenções poéticas e retóricas adotadas pelo texto fonte e pela tradução. Por fim, o último nível estudaria a crítica e teoria da tradução empregadas em literaturas específicas e períodos específicos; grupos ou escolas de tradução; o papel da tradução no desenvolvimento de literaturas etc. Assim, seria possível afastar-se das ideias hegemônicas sobre tradução baseadas em conceitos como "fidelidade" e "qualidade" e que, consequentemente, favoreciam o texto fonte.

O esquema, então, seria uma ferramenta de pesquisa capaz de mostrar as diferentes relações que podem exercer um papel na produção de traduções, englobando aspectos relativos ao processo de tradução, suas características 
textuais, a sua recepção e aspectos sociológicos. Com isso, o processo de tradução pode ser estudado a partir de diferentes pontos de vista, sejam eles macro ou microestruturais, e focar em aspectos como padrões linguísticos, códigos literários, padrões morais ou religiosos, e aspectos não-literários.

Contudo, conforme apontam Lambert e Van Gorp, não é possível fazer uma análise exaustiva do texto em sua totalidade. Logo, caberia analisar diferentes fragmentos a partir do ponto de vista de regras textuais específicas, como olhar para as maneiras como a diferenças entre as línguas fonte e meta pode estar por trás de alterações específicas.

Para os autores, não se pode analisar traduções específicas de maneira adequada se não forem levados em consideração aspectos relacionados a ela, como outras traduções pertencentes aos mesmos sistemas, ou os vários níveis macro e microestruturais em que se inserem. Logo, o modelo proposto por Lambert e Van Gorp pode ser relevante para se estudar traduções queer pois, ao empregá-lo, pode-se evitar o tipo de análise reducionista mencionado acima e melhor compreender como os diferentes aspectos das traduções se interrelacionam para visibilizar ou apagar conteúdos LGBTQAI+ nos textos.

Seguindo o modelo descritivo de Lambert e Van Gorp, a análise começará pelos dados preliminares, como a presença ou ausência de prefácio, posfácio ou notas, com o intuito de averiguar se a não-binariedade de gênero dxs personagens é visibilizada, se as estratégias empregadas pela tradução para manter esse elemento ou os motivos para o seu apagamento são explicitados e se ideologias cis-heteronormativas ou de tradução influenciaram na escolha das estratégias de tradução desses textos. Nos casos em que essas estratégias não foram fornecidas em fontes paratextuais, serão trazidos, quando disponíveis, metatextos que forneçam tais informações. Posteriormente, passarei ao micronível, analisando textualmente as estratégias utilizadas pela tradução: se essas condizem ou não com as informações apresentadas nos dados preliminares e se enfatizam a nãobinariedade de gênero dxs personagens.

\subsection{Perguntas de pesquisa e objetivos}

De forma abrangente, três perguntas principais nortearão a presente pesquisa, podendo estas ser divididas em sub-perguntas: 
1. A não-binariedade de gênero dxs personagens do mangá foi mantida em suas traduções?
a. Quais estratégias foram utilizadas para mantê-la?
b. As estratégias utilizadas visibilizam a não-binariedade de gênero?
c. As traduções que não a mantiveram oferecem alguma justificativa para o apagamento?

2. Ideologias cis-heteronormativas ou de tradução influenciaram nas estratégias empregadas para lidar com essa não-binariedade?

a. A preocupação com a fluência do texto desempenhou um papel na escolha das estratégias tradutórias?

b. As traduções reforçam concepções e/ou usos cis-heteronormativos de linguagem?

3. Apenas manter a não-binariedade de gênero, sem enfatizá-la de alguma maneira, é suficiente para evitar o apagamento dessa característica de suas identidades?

O objetivo da presente pesquisa é, sob o olhar da Teoria da Invisibilidade do Tradutor (VENUTI, 1995, [1998] 2019) e da Tradução Queer (LEWIS, 2010), analisar como diferentes traduções lidaram com a não-binariedade de gênero dxs personagens da obra a fim de tentar aferir se ideologias cis-heteronormativas e de tradução estão por trás das estratégias tradutórias empregadas e como elas podem ter contribuído para o apagamento dessa característica. Concentrando-nos sobre as ideologias que orientam as práticas tradutórias, poderemos melhor compreender como conteúdos LGBTQAI+ presentes nas obras podem ser facilmente apagados em traduções e argumentar em favor da necessidade de um tipo de tradução que não apenas os mantenha, mas também os enfatize.

\subsection{Justificativa e relevância}

A presente pesquisa tem relevância tanto de ordem teórico-acadêmica quanto de ordem social. É de relevância acadêmica porque, apesar de ter havido um aumento no interesse pelo estudo da tradução de tópicos LGBTQAI+, principalmente na última década, a literatura disponível tende a concentrar-se apenas em como os seus elementos foram mantidos e/ou apagados, ou tende a focar em como diferenças na conotação entre os termos utilizados no texto fonte e 
no texto meta podem conferir a esse último uma carga pejorativa ausente no primeiro, ou apagar nuances dos usos da linguagem (ver VALDÉON, 2010; ASIMAKOULAS, 2012; BERLINA, 2012; GORJANC, 2012; RANZATO, 2012; LINDER, 2014; ZOBERMAN, 2014). Encontram-se também trabalhos que se debruçam sobre as relações entre ideologia e o apagamento de identidades LGBTQAI+ em traduções. Flotow ([2005] 2014), por exemplo, aponta a censura direta na forma do Liturgiam Authenticam publicado pelo Vaticano, no qual é especificado que o masculino genérico deve ser usado nas traduções da bíblia, e linguagem inclusiva deve ser evitada. Santaemilia (2008) elenca diversos casos em que alguma censura - seja ela imposta oficialmente por regimes ditatoriais, ou autoimposta pelxs tradutorxs para se conformarem às suas próprias ideologias ou àquelas vigentes na sociedade na época - levou ao apagamento de conteúdo homoerótico em obras traduzidas, ou até mesmo à recusa em se traduzirem textos em que esses elementos estavam presentes. Harvey (1998) observa como elementos do camp speech presentes na obra The City And The Pillar, de Gore Vidal, foram atenuados em sua tradução para o francês publicada em 1981, e como a tradução desse estilo de fala pode estar relacionada às restrições e prioridades vigentes em um dado cenário cultural. Close (2017), por sua vez, analisa a tradução norte-americana do anime Sailor Moon, o qual apresenta diversas personagens que não se conformam à matriz cis-heteronormativa, indo desde personagens lésbicas e homossexuais a personagens transgênero, demonstrando como todas essas identidades foram alteradas na tradução para conformarem-se às normas sociais de gênero e sexualidade, a fim de tornar o material apropriado para crianças.

Ocasionalmente, nos deparamos com artigos que se debruçam sobre o papel que a tradução pode exercer como forma de resistência, seja ao demonstrar como ela pode servir para desafiar normas rígidas de sexualidade em uma determinada literatura ou sociedade (TYULENEV, 2014), seja por concentrar-se em estratégias utilizadas por tradutorxs para contornar as restrições impostas pela censura (BAER, 2011).

Apesar da importância de pesquisas do tipo para se compreender o papel que a tradução pode exercer tanto na marginalização de pessoas LGBTQAI+ quanto como forma de resistência, ainda há pouquíssimos trabalhos que se dedicam ao desenvolvimento de teorias que lidem especificamente com as 
especificidades envolvidas na tradução de conteúdos LGBTQAI+ presentes nos textos. Enquanto fazia a revisão bibliográfica para a escrita da presente dissertação, não encontrei nenhum artigo que tenha dado continuidade às ideias propostas por Lewis (2010). Assim, a presente pesquisa pretende preencher tais lacunas nos Estudos da Tradução adotando uma perspectiva queer para desenvolver teorias que lidem com a tradução de elementos não cisheteronormativos em textos.

Quanto à relevância social, a linguagem pode ter consequências reais nas vidas dos indivíduos. Em um estudo de caráter empírico, Prewitt-Freilino et al (2012) comparam os índices de igualdade de gênero entre 111 países cujas línguas são gramaticalmente generificadas, têm gênero natural, ou são neutras e concluem que países cujas línguas se enquadram no primeiro tipo tendem a apresentar mais desigualdades de gênero em relação aos países em cujas línguas o gênero não é obrigatoriamente marcado. Em relação a pessoas do espectro não-binário especificamente, tanto Hord (2016) quanto Lau (2019) analisam como línguas gramaticalmente generificadas dificultam que essas pessoas expressem suas identidades por meio da linguagem. Considerando que "a representação na linguagem pode ser muito importante para a capacidade de alguém de ter sua identidade compreendida pelxs outrxs e reconhecida nas interações cotidianas da fala" (HORD, 2016, p. $3^{6}$ ), estudar como a tradução pode visibilizar identidades não-binárias pode ajudar a enfrentar o apagamento causado pela falta de representatividade na linguagem e nas mídias.

Além disso, considero o estudo de traduções de mangás bastante útil para atingir esse objetivo, pois o vasto leque de expressões de gênero e sexualidade representadas nessa mídia faz dela um terreno fértil para se pensar em formas de subverter a cis-heteronormatividade. O fato de xs personagens de Houseki no kuni não terem gênero torna essa obra particularmente relevante para se pensar a Tradução Queer, uma vez que xs tradutorxs precisarão ter isso em mente todo o tempo e desenvolver estratégias específicas para não designar um gênero axs personagens. Ademais, o caráter multimodal dos mangás também contribui para pensar se apenas manter a não-binariedade de gênero é suficiente para que uma

\footnotetext{
${ }^{6}$ Utilizei a numeração do leitor de PDF pois o artigo não tem suas páginas numeradas.
} 
tradução seja considerada queer, visto que, se não pela linguagem, xs personagens ainda podem ser generificadxs por uma leitura enviesada das imagens.

\title{
1.4. Gênero e sexualidade nos mangás
}

Não é novidade dentre os fãs de mangás que estes estão muito à frente das mídias ocidentais no que diz respeito à representatividade de identidades LGBTQAI+. Conforme coloca Brenner (2007, p.92),

\begin{abstract}
Nos mangás, gênero e papéis de gênero são muito mais complexos do que poderiam parecer baseados nas interações quotidianas e nas tradições de longa data do Japão. Desafios às noções convencionais de gênero aparecem todo o tempo na mídia popular japonesa, enquanto eles raramente o fazem nos Estados Unidos. [...] Xs autorxs de quadrinhos dos EUA estão começando a brincar com as expectativas de gênero; no Japão, onde as pessoas são socialmente menos tolerantes ao cruzamento das fronteiras entre os gêneros, os quadrinhos são repletos de personagens que contestam os papéis de gênero: travestis, drag queens, pessoas sem gênero ou com mais de um.
\end{abstract}

Em princípio, essa constatação pode parecer um tanto discrepante, visto que os papéis de gênero na sociedade japonesa são bem mais rígidos do que na maioria das sociedades ocidentais, conforme aponta McLelland (2010). No entanto, de acordo com o autor, é justamente essa rigidez dos papéis de gênero na sociedade japonesa que pode explicar a presença abundante de personagens que não se conformam aos padrões cis-heteronormativos. Curiosamente, o autor assinala que a maioria das representações de homossexualidade masculina no Japão ocorrem em mangás voltados para mulheres. Nesses mangás, assim como em muitas outras mídias, essas personagens são retratadas como divergentes de gênero, flertando com o feminino tanto em aparência quanto em sensibilidade. Isso culmina na figura dos Bishōnen (garotos bonitos) ${ }^{7}$, que nesses mangás em particular, tendem a destacar a imagem do homem gay como aquele que apresenta as melhores características de ambos os gêneros. Por outro lado, quadrinhos

\footnotetext{
${ }^{7}$ Nos casos aqui citados, a figura dos bishōnen pode ser um tanto normativa, pois reforça o estereótipo do homem gay como mais "feminino". No entanto, os bishōnen não são sempre homossexuais e não se encontram restritos aos mangás eróticos, sendo, em vez disso, presença constante na cultura popular japonesa: podem estar presentes em mangás e animes voltados tanto para mulheres quanto homens de todas as faixas etárias, na literatura e no teatro, em especial o teatro Takarazuka (que será brevemente abordado mais adiante), etc. Nesses casos, são potencialmente subversivos ao demonstrar que homens "afeminados" não necessariamente serão gays e que há diferentes maneiras de performar a masculinidade que não necessariamente se limitam ao que se entende por masculinidade hegemônica.
} 
voltados para o público masculino representam os homens de forma radicalmente diferente: são desenhados de forma hipermasculinizada, sexualmente agressivos, dominadores e violentos com as parceiras, enquanto essas são coniventes com esse comportamento. Quando não são sexualmente agressivos, os homens são representados como indivíduos tristes e patéticos cujos egos precisam ser constantemente massageados pelas mulheres, que o fazem através do sexo, para o qual estão sempre disponíveis. Representações semelhantes podem ser vistas em mangás pornográficos gays, onde os homens, além das características apresentadas acima, são também frequentemente retratados como pervertidos sexuais. Conforme a análise de McLelland, o sexo heterossexual raramente apresenta relações de poder igualitárias e raramente acontecem no contexto de um relacionamento, ou levam a um.

O autor assinala que tanto esse interesse por parte do público feminino em estórias que envolvem relacionamentos entre homens quanto as representações de sexo heterossexual mencionadas acima têm relação com as representações da sexualidade feminina na cultura japonesa. Para McLelland, há dois pesos e duas medidas no que diz respeito às formas como homens e mulheres podem expressar as suas sexualidades: ao mesmo tempo em que existe uma grande indústria do sexo, que emprega mulheres tanto japonesas quanto estrangeiras, para satisfazer as fantasias dos homens, a única forma de expressão da sexualidade tradicionalmente permitida às mulheres deve ocorrer dentro dos limites do casamento. Contudo, durante a década de 1970, após conquistas tanto sociais quanto econômicas, as mulheres passaram a exigir os seus direitos de expressar-se sexualmente fora dele. Isso levou a uma intensa reação negativa por parte da mídia, que desse momento em diante passou a figurar imagens que demonstram a degradação da mulher como consequência do sexo, reportagens sensacionalistas sobre como mulheres que têm relações sexuais com estrangeiros seriam responsáveis por trazer o HIV para o país, além de criarem a imagem do "feto ameaçador", que estaria à espera daquelas que ousassem ter relações fora do casamento. Consequentemente, criou-se a ideia de que mulheres que querem sexo fora do casamento devem ser punidas, culminando na forma violenta e humilhante como as mulheres são tratadas na pornografia japonesa. Soma-se a isso o fato de o uso efetivo de métodos contraceptivos ainda ser difícil no Japão, de forma que a sexualidade feminina é limitada também pelo medo da gravidez. 
Tendo em vista esses fatores, fica mais fácil compreender o fascínio das mulheres japonesas pelas estórias de amor entre homens andróginos. Conforme coloca McLelland (2010, p. 83):

$\mathrm{Na}$ sociedade japonesa, onde os papéis de gênero foram rigidamente fixados, a cultura popular voltada para as mulheres fornece um espaço seguro no qual o regime normalmente não negociável de gênero pode ser subvertido e derrubado. Não é nenhuma surpresa, então, que as mulheres, cuja sexualidade pode ser seriamente restringida por sua associação, no imaginário popular, tanto com o comércio sexual quanto com maternidade, achem essas fantasias tão atraentes e estejam tão envolvidas em sua produção e consumo.

Dessa forma, a temática desse tipo de mangá “[...] não é a homossexualidade masculina, mas uma reflexão sobre os sentimentos e desejos femininos, resguardos sob a máscara de outras histórias" (ARANHA, 2010, p. 249).

Apesar de o trabalho de McLelland debruçar-se principalmente sobre mangás com conteúdo explicitamente erótico, o apagamento das fronteiras entre os gêneros e relacionamentos homoafetivos não se limitam a essas obras. Em "The Power of Truth: Gender and Sexuality in Manga", Tania Darlington e Sara Cooper analisam diversos mangás tendo como foco as diferentes maneiras em que as questões de gênero e sexualidade são abordadas nessas obras. As autoras observam que, diferente do que ocorre no Ocidente, representações de relacionamentos homoafetivos e fluidez de gênero são comuns em mangás voltados para as mais diversas faixas etárias. De acordo com as autoras,

[...] embora a homossexualidade como estilo de vida não seja necessariamente tolerada no Japão, já há algum tempo a diversidade sexual e de gênero, assim como o amor espiritual e emocional entre parceiros do mesmo sexo, têm recebido um lugar de importância em gêneros de mangá. (DARLINGTON \& COOPER, 2010, p. 166)

As autoras apontam, também, que apesar de o mangá ter surgido em sua forma moderna apenas na segunda metade do século $\mathrm{XX}$, concepções de performance e ambiguidade de gênero têm sido explorados no teatro japonês há séculos, com um longo histórico de performances que reproduzem ao mesmo tempo em que desestabilizam divisões tradicionais entre os papéis masculinos e femininos tanto nos palcos quanto fora deles. As autoras citam como exemplo o 
famoso teatro Kabuki, no qual todas as personagens, tanto as masculinas quanto as femininas, são interpretadas por homens. Contudo, é em sua contraparte, o teatro Takarazuka, que as autoras apontam as origens do apagamento das fronteiras de gênero nos mangás. Todos os papéis das peças produzidas por esse teatro são interpretados por atrizes, dentre as quais, aquelas que interpretam papéis masculinos são reverenciadas por isso e frequentemente cultivam um fascínio romântico como homens (BRENNER, 2007). Osamu Tezuka, autor de diversos mangás e responsável por desenvolver a linguagem desse meio de expressão como a conhecemos hoje, cresceu próximo a esse teatro e foi profundamente influenciado por ele na criação de sua obra A princesa e o cavaleiro, que tem como personagem principal uma princesa que foi criada como um menino durante toda a vida de forma a se conformar às leis de herança e impedir que o reino caísse em mãos inimigas (BRENNER, 2007). Influências semelhantes podem ser vistas em obras com personagens femininas que assumem identidades masculinas (Utena, Rosa de Versalhes), obras em que mulheres se relacionam ou demonstram interesse em mulheres que apresentam performances e estilizações corporais mais "masculinizadas" (Sailor Moon), além de obras em que, por motivos variados, suas personagens trocam de gênero (Ranma 1/2, Tenshi na konamaiki).

No entanto, é importante ressaltar que o fato de haver uma maior representatividade de personagens LGBTQAI+ em mangás do que se costuma encontrar nas histórias em quadrinhos ocidentais não significa que sua representação não seja muitas vezes problemática. São inúmeros os casos de personagens homossexuais tendo a sua sexualidade representada de forma estereotipada para efeitos de humor, como a personagem General Blue, da série Dragon Ball, por exemplo, cujo humor associado a ele deriva primariamente da maneira "afeminada" como é retratado, o que pode reforçar tanto o estereótipo do homem gay como mais "feminino" quanto o estigma que geralmente é associado aos homens gays que o são. Há também casos mais extremos, como a personagem Puri-Puri Prisioner, do mangá One-Punch man, que não apenas é representado de forma caricata, como também associa a homossexualidade à perversão sexual, chegando a ser insinuado que a personagem mantém relações sexuais com indivíduos contra a sua vontade (tudo isso também para efeitos de humor!). Contudo, apesar desses eventuais casos problemáticos, é seguro afirmar que representações que escarnecem das expectativas de gênero impostas pela 
sociedade japonesa aos indivíduos não são, de forma alguma, tabu (DARLINGTON \& COOPER, 2010).

Assim, podemos encontrar todo tipo de identidades LGBTQAI+ sendo representadas em mangás das mais diversas maneiras, seja como temas centrais da obra (como nos gêneros yaoi e yuri, voltados para o público adulto e que giram em torno de relacionamentos gays e lésbicos, respectivamente), seja como personagens secundárias com as suas sexualidades retratadas de forma naturalizada. Pode-se ainda encontrar casos em que esse aspecto fica relegado ao segundo plano, sendo apenas uma característica das personagens que está presente, mas não tem nenhuma relevância para a estória e raramente é mencionada. É nesse último grupo que se enquadra a obra que será o objeto de análise da presente pesquisa.

\subsection{Houseki no kuni}

Houseki no Kuni é uma série em mangá seinen (mangás voltados para o público adulto, com temáticas mais maduras) escrito e ilustrado por Haruko Ichikawa, cuja serialização teve início em outubro 2012 e, até o momento da escrita deste trabalho, ainda se encontrava em andamento.

A obra passa-se em um mundo pós-apocalíptico onde, após uma série de desastres naturais, os seres humanos deixaram de existir e o território habitável do planeta foi reduzido a uma pequena ilha. Após milhares de anos, essa ilha passou a ser povoada por formas de vida minerais antropomórficas e imortais, xs quais são acolhidxs pelo enigmático sensei ${ }^{8}$ Kongo desde o nascimento. Essxs gemas encontram-se em conflito com os lunárixs, que, como o nome sugere, habitam as luas que orbitam o planeta e descem periodicamente para tentar raptá-lxs, supostamente pelo seu valor como decoração. A estória acompanha o desenvolvimento $\mathrm{dx}$ protagonista Fosfofilita (xs personagens têm seus nomes derivados dos minerais que xs compõem), que, após ter a tarefa de compilar uma enciclopédia de história natural lhe atribuída pelo Kongo, procura a ajuda de Cinabarita e toma ciência de seu isolamento autoimposto devido a sua condição que impede o contato com outras pessoas. Após prometer encontrar-lhe um

\footnotetext{
${ }^{8}$ Forma de tratamento que demonstra grande admiração e respeito ao se referir a uma pessoa muito experiente em determinado assunto. Geralmente é utilizada para se dirigir a professorxs, mestrxs ou doutorxs.
} 
propósito, Fosfofilita parte em uma busca que abalará suas convicções e fará com que questione a real natureza do sensei e sua conexão com os lunárixs.

Utilizando-se desse cenário, com uma arte delicada e bom humor que não hesita em assumir tons mais sombrios quando necessário, Ichikawa explora questões relacionadas à mortalidade, luto, apego e a busca por um lugar no mundo a partir de uma perspectiva budista.

O mangá de Ichikawa destaca-se dos demais tipos de mangás abordados na seção anterior pela forma como sua autora aborda a questão do gênero: xs gemas que compõem o núcleo principal $\mathrm{dxs}$ personagens não têm um gênero especificado, não sendo, dessa forma, nem homens nem mulheres ${ }^{9}$. Essa característica é bastante evidente na maneira como Ichikawa opta por desenhar os seus corpos: todxs xs personagens apresentam as mesmas dimensões corporais, variando apenas em seus rostos e nas roupas que vestem; além disso, são desenhadxs com torsos que apresentam características ideologicamente associadas com o masculino, porém, suas pernas, cintura e quadris apresentam características ideologicamente associadas ao feminino. Isso causa o efeito interessante de fazer com que umx mesmx personagem apresente uma aparência mais "masculina" em uma determinada vinheta e assuma uma aparência mais "feminina" em outra. No entanto, algumas dxs personagens conformam-se às convenções geralmente associadas às personagens femininas de mangás ${ }^{10}$ : olhos grandes, com formato arredondado e íris também grandes (BRENNER, 2007). Devido a esse fator, é favorecida a sua leitura como femininas.

\footnotetext{
${ }^{9}$ Por não serem exatamente humanxs, e pelo fato de estarem inseridxs em uma sociedade na qual não há um conceito de gênero, tanto xs personagens quanto as situações nas quais estão inseridxs não são exatamente representativos do que são pessoas que se identificam como não-binárixs e suas vivências em uma sociedade que xs marginaliza. Entretanto, na presente pesquisa, irei me referir axs gemas como não-binárixs pois a sua presença na obra tem o potencial de desestabilizar a matriz cis-heteronormativa da mesma maneira que o fazem pessoas que se identificam como não-binárixs (ver seção 2.3.1), e os obstáculos presentes na tradução do mangá Houseki no kuni compartilha de muitos dos desafios que essas pessoas enfrentam no uso da linguagem, podendo servir para iluminar tais questões e demonstrar a necessidade de se pensar em formas de uso da linguagem que sejam mais inclusivas.

${ }^{10}$ Embora o mesmo não se aplique a todxs xs personagens do mangá, com muitas delxs apresentando uma aparência bastante andrógina.
} 


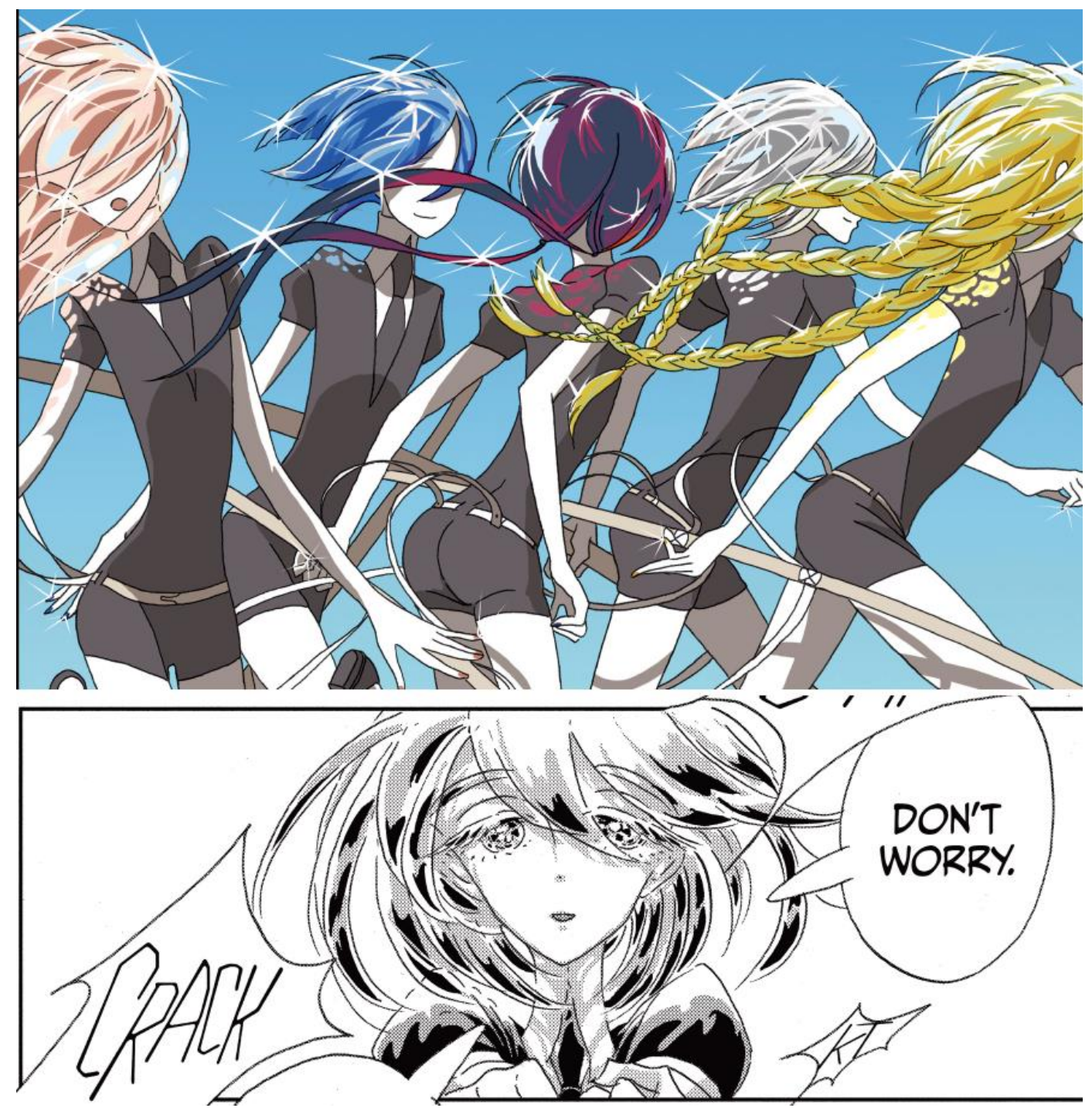

Figura 1: torso e rosto dxs personagens

Assim, tanto a maneira como algumxs dxs personagens são desenhadxs quanto a posição secundária que a não-binariedade do seu gênero ocupa no enredo fazem com que seja relativamente fácil que tradutorxs acabem por designar-lhes um gênero ao traduzirem o texto. $O$ segundo desses fatores é particularmente relevante para essa pesquisa, dado que é um elemento que pode ser facilmente apagado sem que se causem grandes perdas na narrativa e, tendo em vista as dificuldades envolvidas na manutenção da não-binariedade de gênero dxs personagens, xs tradutorxs podem se ver tentadxs a apagar essa característica da obra. Em traduções para línguas gramaticalmente generificadas como as neolatinas, torna-se ainda mais difícil lidar com esse aspecto, visto que a própria estrutura da língua impõe barreiras à sua tradução. De fato, como veremos mais 
adiante, essa dificuldade causada pela língua é utilizada como justificativa para o apagamento das identidades não-binárias dxs personagens do mangá.

A vasta gama de expressões de gênero e sexualidade representadas em mangás faz desse meio um terreno fértil para se pensar em formas de subverter a hegemonia cis-heteronormativa. Logo, é importante que suas traduções tenham cuidado ao lidar com as dificuldades envolvidas na manutenção desses elementos, de maneira que essas identidades não se apaguem e seu potencial subversivo se perca.

\subsection{Organização da dissertação}

O presente texto é organizado em quatro capítulos, sendo esta introdução o primeiro. Optei por incluir alguns elementos que tradicionalmente não fazem parte da introdução de uma dissertação, como um resumo das maneiras como gênero e sexualidade são tratadas nos mangás e um resumo da obra cujas traduções analiso porque, no caso do primeiro, acredito que não faria sentido dedicar um capítulo inteiro à exploração dessas representações, já que elas não são o tema da pesquisa. Bastava que fosse feito um resumo para esclarecer o porquê de considerar que a tradução de mangás pode contribuir para subverter a matriz cis-heteronormativa. Inseri o resumo da obra logo em seguida, pois considerei ser o único ponto da dissertação em que isso poderia ser feito sem comprometer a fluidez do texto.

O segundo capítulo corresponde à fundamentação teórica da minha dissertação, na qual exploro a ideia de tradução como forma de resistência. $\mathrm{O}$ capítulo inicia-se com uma discussão acerca dos principais conceitos da Teoria da Invisibilidade do Tradutor, de Venuti, para pensar no potencial que a tradução pode ter tanto como ferramenta de dominação quanto como forma de resistir a ela. Em seguida, volto-me ao trabalho das tradutoras feministas, que apontam as relações que existem entre linguagem e desigualdades gênero e utilizam a tradução como forma de expor e reagir a essas injustiças. Por fim, encerro o capítulo com a Tradução Queer para falar especificamente da relação entre tradução e apagamento de identidades LGBTQAI+.

No terceiro capítulo, parto para a análise das cinco traduções que compõem o corpus de análise da minha dissertação, debruçando-me tanto nos textos 
traduzidos em si quanto em informações sobre essas traduções retiradas de fontes meta e paratextuais, nos casos em que essas encontravam-se disponíveis. Examinarei se a não-binariedade de gênero dxs personagens foi mantida e/ou apagada. No caso de traduções que a mantiveram, analisarei as estratégias utilizadas em sua manutenção, e nos casos em que foi apagada, analisarei as motivações que levaram a tal apagamento a fim de tentar aferir se foi motivado por influência de ideologias cis-heteronormativas ou de tradução.

Por fim, no quarto capítulo, teço as considerações finais sobre a presente dissertação, amarrando os fios tecidos ao longo do trabalho sobre as implicações que as ideologias cis-heteronormativas e sobre tradução têm sobre o apagamento de identidades LGBTQAI+, as maneiras nas quais essas ideologias manifestam-se nas estratégias tradutórias e nos discursos dxs tradutorxs e a importância de um tipo de tradução que desestabilize a matriz cis-heteronormativa. 


\section{Visibilização como resistência: da Invisibilidade do Tradutor à Tradução Queer}

A presente pesquisa parte do ponto de vista de que "há sempre um contexto no qual a tradução ocorre, há sempre uma história da qual um texto emerge e ao qual é transposto" (LEFEVERE; BASSNET, 1990, p.11). Com isso, quero dizer que é um ato realizado por indivíduos inseridos em contextos sócio-históricoculturais e que está sujeito às ideologias que os orientam e aos valores hegemônicos das culturas receptoras, podendo, muitas vezes, servir como ferramenta de dominação e exclusão. Contudo, pode também assumir um olhar crítico em relação à natureza ideológica do texto fonte e das traduções, de forma a tornar-se um instrumento de resistência.

\subsection{A Invisibilidade do Tradutor}

Para se pensar essa ideia da tradução como uma forma de reproduzir e/ou resistir a ideologias dominantes, vale a pena retomar o trabalho de Lawrence Venuti e os seus conceitos de tradução domesticadora e tradução estrangeirizadora. Esses conceitos derivam de dois tipos de estratégias tradutórias delineadas por Friedrich Schleiermacher, para o qual tradutorxs podem tomar dois caminhos ao traduzir um texto: deixar $\mathrm{x}$ autorx em paz e levar $\mathrm{x}$ leitorx até elx, ou deixar $\mathrm{x}$ leitorx em paz e levar $x$ autorx até elx (MARTINS, 2010). Basicamente, isso significa dizer que xs tradutorxs podem escolher adotar uma estratégia de tradução que adeque o texto às convenções poetológicas e às normas de linguagem dominantes na cultura meta, ou adotar uma estratégia que enfatize o caráter estrangeiro do texto fonte. Venuti denomina essas duas estratégias domesticação e estrangeirização, respectivamente; porém, acrescenta a elas um caráter ideológico.

Uma tradução domesticadora seria uma consequência de dois conceitos inter-relacionados: o conceito de fluência e o de invisibilidade. Fluência diz respeito à maneira como textos traduzidos tendem a ser lidos e avaliados. Em seu livro The Translator's Invisibility - A History of Translation, Venuti observa, a partir de uma análise dos cenários editoriais no Reino Unido e nos Estados Unidos, que textos traduzidos nesses países tendem a ser considerados aceitáveis quando sua leitura é fluente, isto é, 
quando a ausência de qualquer peculiaridade linguística ou estilística faz com que [o texto] pareça transparente, dando a impressão de que reflete a personalidade ou intenção $\mathrm{dx}$ escritorx estrangeirx, ou o sentido essencial do texto estrangeiro - a aparência, em outras palavras, de que a tradução não é de fato uma tradução, mas o “original” (VENUTI, [1995] 2008, p.1).

Sua afirmação é corroborada por análises de diversas resenhas nas quais a fluência e a naturalidade são as principais características elogiadas nas traduções, e a sua ausência, o principal motivo de crítica. É também a partir dessas resenhas que Venuti determina as características responsáveis por produzir um texto fluente, sendo elas: ser escrita em uma linguagem moderna e padrão, que evite o uso de jargões, arcaísmos, ou palavras e fraseio estrangeiros, além de possuir uma sintaxe que corresponda a da língua de chegada. Ou seja, nesse tipo de tradução, priorizase a clareza e a legibilidade do texto.

A invisibilidade, por sua vez, é um efeito dessa tendência: devido à forma como as traduções são avaliadas, xs próprixs tradutorxs, muitas vezes, mascaram seu trabalho, de modo que esse se torne "invisível" e crie um efeito de transparência que causa a impressão de que o que se lê não é uma tradução. Em outras palavras: "a estratégia de fluência [...] busca apagar a intervenção do tradutor no texto traduzido e anula[r] a diferença linguística e cultural do texto estrangeiro" (MARTINS, 2010, p.66). Logo, a invisibilidade, para Venuti, decorre de dois fatores principais: (1) da forma como xs tradutorxs desses países tendem a traduzir textos de maneira "fluente" e (2) da maneira como os textos traduzidos são geralmente lidos e avaliados na cultura meta.

A adoção de tais práticas resulta em traduções domesticadoras, cujos efeitos são muito bem ilustrados nos estudos de caso sobre os quais se debruça em seu livro posterior, Escândalos da tradução: por uma ética da diferença. Dentre eles é notável o caso da tradução de um artigo que apresentava uma história dos povos mexicanos publicada pela revista Courier, da Unesco, em abril de 1990. Nela, o termo antiguos mexicanos (antigos mexicanos) é traduzido como indians (índios), distanciando-xs dxs colonizadorxs espanhóis; sabios é traduzido como diviners (advinhxs), ligando-os ao misticismo e opondo-os ao racionalismo europeu; testimonias (testemunhos) foi traduzido como written records (registros escritos), privilegiando as tradições literárias em detrimento das orais. Além disso, o termo memoria, ligado ao costume de transmissão oral de conhecimento nessas culturas, 
foi traduzido tanto como history (história) e knowledge of the past (conhecimento do passado), quanto como memory (memória). Ademais, a tradução editou o texto espanhol, diminuindo a cultura nativa ao simplificar a sintaxe e omitir outro termo chave: mitos. Assim, um trecho como "Los mitos y leyendas, la tradición oral y el gran conjunto de inscripciones perpetuaron la memoria de tales aconteceres" [Os mitos e lendas, a tradição oral e o grande conjunto de inscrições perpetuaram a memória de tais eventos] ficou: "The memory of these events lives on in the thousands of inscriptions and legends of oral tradition" [a memória desses acontecimentos sobrevive em milhares de inscrições e nas lendas de tradição oral]. Segundo Venuti ([1998] 2019, p.138),

\begin{abstract}
Os padrões tradutológicos que venham a ser razoavelmente estabelecidos fixam estereótipos para culturas estrangeiras, excluindo valores, debates e conflitos que não estejam a serviço de agendas domésticas. Ao criar estereótipos, a tradução pode vincular respeito ou estigma a grupos étnicos, raciais e nacionais específicos, gerando respeito pela diferença cultural ou aversão baseada no etnocentrismo, racismo ou patriotismo. Em longo prazo, a tradução penetra nas relações geopolíticas ao estabelecer as bases culturais da diplomacia, reforçando alianças, antagonismos e hegemonias entre nações.
\end{abstract}

Sendo assim, a tradução publicada pela revista Courier é carregada de um viés ideológico contra os povos mexicanos pré-colombianos, cuja cultura oral é representada como inferior e antiquada.

O caso da formação dos cânones da literatura japonesa nos Estados Unidos é outro exemplo notável da prática de domesticação. Durante as décadas de 1950 e 1960, editoras estadunidenses como a Grove Press, Alfred Knopf e New Directions lançaram muitas traduções de romances e coletâneas de contos japoneses. Contudo, as escolhas dessas editoras focaram em poucxs escritorxs, entre elxs Jun'ichiro Tanizaki, Yasunari Kuwabata, Kenzaburō Ōe e Yukio Mishima. Essa escolha limitada de autorxs criou um cânone de literatura japonesa na língua inglesa que passava a imagem do povo japonês como evasivo, obscuro, inconcluso, além de taciturno e melancólico. Ademais, a ficção traduzida durante esse período fazia alusão à cultura japonesa tradicional e, muitas vezes, lamentava as mudanças sociais causadas por conflitos militares e por influência ocidental. Considerando o contexto do pós-guerra em que essas traduções foram publicadas, percebe-se que há por trás da escolha dessxs autorxs um interesse em construir uma imagem da cultura japonesa que se opusesse à imagem do Japão como a 
potência bélica que se tinha no Ocidente. A escolha dos textos foi feita principalmente por professorxs universitárixs especializadxs em literatura japonesa que sugeriam às editoras quais textos deveriam ser traduzidos e publicados, de forma que

[...] uma comunidade cultural específica controla a representação de literaturas estrangeiras para outras comunidades na cultura doméstica, privilegiando certos valores domésticos enquanto exclui outros e estabelecendo um cânone de textos estrangeiros que é necessariamente parcial porque está a serviço de certos interesses domésticos (VENUTI, [1998] 2019, p.145).

Posteriormente, na década de 1980, esse cânone passou a ser questionado por uma nova geração de escritorxs e leitorxs de língua inglesa. Guiados por um ceticismo em relação a essa imagem da cultura japonesa criada por essas traduções, essxs leitorxs e escritorxs buscaram obras que apresentassem outras formas e temas. Dentre elxs, destaca-se Alfred Birnbaum, um jornalista estadunidense que vive no Japão desde a infância. Com o intuito de contestar o cânone disponível, Alfred publica uma antologia intitulada Monkey Brain Sushi, na qual evita deliberadamente autorxs como xs previamente publicadxs, privilegiando aquelxs nascidxs e criadxs em um Japão pós-guerra americanizado e cujos textos são amplamente lidos pela população japonesa. Um projeto tradutório semelhante aparece na antologia New Japanese Voices, de Helen Mitsios. A representação dxs japonesxs como jovens extremamente ocidentalizadxs foi objeto de fascinação e acarretou em uma reforma do cânone e na imagem que xs estadunidenses tinham do povo japonês. Contudo, essa não escapa de ser também uma visão reducionista: enquanto o primeiro cânone cria uma imagem dxs japonesxs como um povo tradicional, esse último o projeta como um povo altamente americanizado; ou seja, houve apenas um salto de um estereótipo para outro.

Os exemplos fornecidos por Venuti no decorrer de seu livro demonstram como um projeto tradutório com viés domesticador pode ser prejudicial para a representação de identidades culturais. Conforme pode-se ver nos exemplos acima, tanto as escolhas tradutórias empregadas pelxs tradutorxs quanto a escolha de quais textos serão traduzidos podem servir para apagar aspectos importantes das culturas de onde esses textos originam-se. Traduções desse tipo são duramente criticadas pelo autor, pois envolvem uma redução etnocêntrica do texto e da 
cultura estrangeiros aos valores da cultura meta que tende a apagar o que é particular a esses. A prática tradutória hegemônica seria, então, marcada por uma ideologia de dominação que assimila x outrx, apagando-x no processo.

Caberia, então, axs tradutorxs adotarem um projeto tradutório comprometido com uma "ética da diferença", isto é, um projeto tradutório que "altera [...] a reprodução das ideologias e instituições domésticas dominantes que proporcionam uma representação parcial das culturas estrangeiras e marginalizam outras comunidades domésticas" (VENUTI, [1998] 2019, p.168). Esse objetivo poderia ser atingido através da adoção de estratégias estrangeirizadoras de tradução, as quais consistem em um movimento oposto ao da domesticação. Nas palavras de Venuti ([1995] 2008, p.16, grifos meus):

\begin{abstract}
A estrangeirização evidencia as diferenças do texto estrangeiro, ainda que apenas perturbando os códigos culturais que prevalecem na língua meta. No seu esforço de agradar ao estrangeiro, essa prática tradutória precisa desagradar o doméstico, desviando o suficiente das normas nativas para criar uma experiência de leitura alheia - optando por traduzir um texto estrangeiro excluído pelos cânones literários, ou utilizando um discurso marginal para traduzi-lo.
\end{abstract}

Em um projeto desse tipo, tanto a escolha dos textos a serem traduzidos quanto as escolhas tradutórias empregadas pelxs tradutorxs têm como objetivo fazer com que xs leitorxs da cultura meta estejam cientes de que estão diante de um texto pertencente a uma cultura diferente e, sendo assim, possui diferenças linguísticas e culturais que lhe são inerentes. Esse resultado é conseguido através do emprego de um estilo de tradução não fluente, que cause estranhamento nxs leitorxs, de forma a ressaltar a presença $\mathrm{dx}$ tradutorx e a identidade estrangeira do texto. Todavia, Venuti ressalta que adotar a estratégia de estrangeirização não significa abandonar a fluência por completo pois " $\mathrm{x}$ tradutorx estrangeirizador procura expandir o alcance das práticas tradutórias não para frustrar ou impedir a leitura [...], mas para criar novas condições de legibilidade" (VENUTI, [1995] 2008, p.19).

A prática de estrangeirização seria uma forma de escrita de resistência (FROTA, 2000) empregada pelxs tradutorxs tanto contra a invisibilidade à qual estão sujeitxs quanto contra o apagamento dx outrx em traduções promovido pela prática domesticadora hegemônica. Segundo Venuti, todos os passos envolvidos no processo de tradução são mediados pelos valores, crenças e representações que 
circulam na língua meta. Xs tradutorxs podem submeter-se ou resistir às políticas, formas e instituições que acumularam o maior prestígio e poder nessa língua. Submeter-se significaria adotar uma postura domesticadora, enquanto resistir implicaria em uma postura estrangeirizadora. Se consideramos que “[...] assimetrias, injustiças, relações de dominação e dependência existem em cada ato de tradução, em cada ato de colocar o traduzido a serviço da cultura tradutora" (VENUTI, [1998] 2019, p. 16), então, caberia axs tradutorxs resistir a essas práticas domesticadoras. Para isso, "a seleção de um texto estrangeiro para tradução e a invenção de uma estratégia discursiva para traduzi-lo devem basearse em uma avaliação crítica da cultura receptora, suas hierarquias e exclusões, suas relações com culturas estrangeiras em todo o mundo" (VENUTI, [1995] 2008, p.267).

Segundo a perspectiva de Venuti, toda tradução tem efeitos sociais de longo alcance que podem contribuir para a reprodução de valores hegemônicos ou para a mudança social ao formar identidades culturais. Sendo assim, é necessário olhar criticamente para essas traduções, avaliar os seus efeitos e indagar se elas agem como instrumento de reprodução de ideologias de dominação, ou se agem como instrumento de resistência.

\subsection{Tradução feminista}

Um segundo exemplo de tradução como forma de resistência pode ser visto nas práticas das tradutoras feministas canadenses. Porém, nesse caso, em vez de dedicar-se a visibilizar o estrangeiro e evitar a construção de identidades culturais potencialmente estereotípicas e perniciosas, suas traduções configuram-se como uma forma de resistir ao apagamento sofrido pela mulher tanto na sociedade quanto na linguagem.

Em artigo publicado em 1991, Luise von Flotow procura demonstrar a importância da tradução feminista apresentando o contexto no qual está inserida, assim como as suas práticas e as teorias que as embasam. A autora dá início ao seu artigo com um problema de tradução: como traduzir para o inglês a frase "Ce soir, j'entre dans l'historie sans relever ma jupe" [esta noite entro para a história sem levantar minha saia]. Para Flotow, haveria 
[...] duxs tradutorxs disponíveis para a tarefa: umx com visões mais ou menos tradicionais sobre a importância da "fidelidade" e "equivalência" na tradução, que acredita que o trabalho dx tradutorx deveria ser transparente, e não discutido ${ }^{11}$. A outra é a tradutora feminista (1991, p. 69, grifos meus).

A diferença de pontos de vista dxs tradutorxs resultaria em duas traduções completamente distintas dessa mesma frase: enquanto x primeirx faria a tradução mais próxima ao texto fonte "this evening I'm entering history without pulling up my skirt", a tradutora feminista traduziria a mesma frase como "this evening I'm entering history without opening my legs" [esta noite, entro para a história sem abrir minhas pernas]. Flotow não busca, com seu artigo, julgar qual das duas traduções é melhor ou mais apropriada, mas sim demonstrar o que torna a opção da tradutora feminista não apenas aceitável, mas também desejável.

No exemplo de tradução feminista oferecido por Flotow, a intervenção feita pela tradutora é bem mais evidente do que no exemplo de tradução mais tradicional. Isso se deve ao fato de a tradução feminista ter-se desenvolvido como um método cujo foco é criticar a linguagem patriarcal e dar voz às mulheres através de usos inovadores da língua (SCHÄFFER, 2010). Em seus trabalhos, as tradutoras buscavam visibilizar as mulheres e, ao mesmo tempo, expor a misoginia que subjaz aos usos convencionais da linguagem. Para elas, "a linguagem patriarcal 'convencional e prescritiva' precisava ser desfeita para que as palavras das mulheres se desenvolvessem, encontrassem espaço e fossem ouvidas" (FLOTOW, 1991, p. 73). De forma semelhante à teoria de Venuti, esse objetivo era alcançado tanto por meio da escolha de textos para tradução traduzindo-se textos teóricos e literários escritos por mulheres como forma de enfatizar a sua produção intelectual e aumentar a oferta de obras de autoras femininas disponíveis - quanto através da forma como os textos eram traduzidos.

Em relação às maneiras como esses textos eram traduzidos, as tradutoras feministas empregavam táticas variadas. Porém, Flotow destaca, em seu artigo, aquelas que considera mais importantes, sendo elas: a complementação (supplementing), a tática de hijacking e a escrita de prefácios e notas de tradutora.

\footnotetext{
${ }^{11}$ No texto fonte, a autora escreve "a translator's work should be seen through, and not heard about" em referência a expressão misógina "a woman should be seen, and not heard" [uma mulher deve ser vista, e não ouvida]. Traduzi dessa maneira pois não consegui reproduzir o jogo de palavras da autora em português.
} 
A tática de complementação diz respeito a um problema que afeta toda tradução: o fato de as diferenças entre as línguas, muitas vezes, dificultarem que um determinado recurso utilizado no texto fonte (um trocadilho, ou termos ambíguos, por exemplo) seja mantido na tradução, de forma que xs tradutorxs precisam intervir no texto para compensar pelas diferenças entre as línguas. Contudo, devido ao propósito da tradução feminista de criticar a linguagem patriarcal e ao contexto em que surgiu - no qual se traduziam textos de escritoras feministas do Quebec -, essa tática consistia não apenas em compensar por essas diferenças, mas também em transformar a crítica a uma língua em uma crítica à outra. Um exemplo disso é a crítica que essas escritoras feministas faziam ao patriarcado utilizando-se da vogal "e", que marca o feminino em muitas palavras francesas. Isso representava um grande problema em traduções desses textos para o inglês, já que a ausência do gênero gramatical nessa língua significava que a crítica não poderia ser recriada no texto meta. Para contornar isso, as tradutoras feministas intervinham no texto para compensar por essas diferenças. Um exemplo disso é fornecido por Flotow (1991), segundo a qual, na tradução do livro L'Euguélione, de Louky Bersianik, no qual aparece a frase "Le ou la

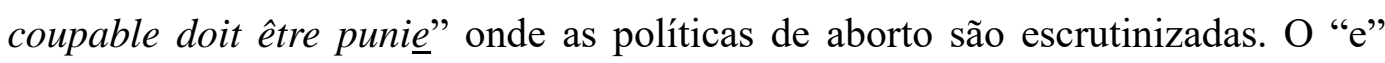
extra ao final de "punie" serve para indicar que a mulher é quem será punida pelo aborto, porém, devido ao fato de essa sutileza não poder ser traduzida para o inglês, Scott optou por traduzir a frase como "The guilty one will be punished, whether she is a man or a woman". Na tradução feminista, a tática de complementação também se caracterizava pela criação de neologismos na língua meta para lidar com os neologismos do texto fonte, como as palavras "his-story" e "auther" para traduzir os termos "histoire" e "auteure" respectivamente (FLOTOW, 1991; DÉPÊCHE, 2000).

Já na tática de hijacking, a tradutora apropria-se do texto e efetua mudanças de forma deliberada por motivos políticos, como substituir termos misóginos, racistas ou LGBTfóbicos presentes no texto fonte por um mais politicamente correto na tradução. Flotow (2014) oferece um exemplo dessa tática ao analisar as traduções de textos abolicionistas escritos por mulheres francesas (entre elas Mme. de Stael, Mme. de Gouge e Mme. de Duras) e publicados no livro Translating Slavery: Gender and Race in French Women's Writing - 1783-1823, de 1994. Segundo a autora, esses textos jamais haviam sido publicados em inglês e eram 
considerados trabalhos de mulheres intelectuais importantes para o movimento feminista. Contudo, os textos apresentavam uma série de problemas, entre eles a linguagem utilizada para referir-se a pessoas negras. De acordo com Flotow, a palavra "selvagem" era frequentemente utilizada para referir-se axs escravxs que estariam para ser libertadxs. Além disso, a linguagem das heroínas negras foi ajustada para fazer com que parecessem mais eloquentes e menos fracas. Essas alterações foram feitas não apenas porque, da maneira que apareciam no texto fonte, poderiam ser consideradas ofensivas, mas também porque “[...] as escritoras [...] deveriam ser vistas como precursoras libertárias do movimento feminista. Não poderia ser dada a elas a linguagem dxs racistas” (FLOTOW, 2014. p.46-47).

O exemplo acima ilustra não apenas em que consiste a tática de hijacking, mas também o que pode torná-la bastante problemática. Como pudemos ver, essa tática tem motivações ideológicas evidentes: as escolhas feitas na tradução dos textos das autoras francesas foram feitas para servir às pautas do movimento feminista, mantendo as características que eram convenientes e apagando as que não eram (ou transformando-as em outras mais adequadas a esse propósito). Levando em consideração que as traduções são, muitas vezes, responsáveis por criar a imagem de umx autorx ou literatura projetada no exterior (LEFEVERE, 1992), o emprego dessa tática pode fazer com que o caráter misógino, LGBTfóbico ou racista de um texto ou autorx seja apagado. Isso é especialmente relevante em casos como o exemplo acima, nos quais a tradução será o primeiro texto de umx determinadx autorx introduzido na cultura meta, de forma que será a partir dela que xs leitorxs terão o seu primeiro contato. $\mathrm{O}$ fato de ser exatamente esse o objetivo da tradução em questão não torna o hijacking menos controverso, fazendo com que seja aconselhável que venha acompanhada de prefácios ou notas de tradução explicando as motivações que levaram ao seu emprego. O que nos leva à terceira tática mencionada acima.

A escrita de prefácios e notas de tradutora tornaram-se rotineiras para as tradutoras feministas e são utilizadas para refletir sobre o seu trabalho e enfatizar a sua presença ativa no texto (FLOTOW, 1991). Essa tática é frequentemente empregada para explicar decisões tradutórias tomadas ou jogos de palavras presentes no texto fonte que não puderam ser reproduzidos na língua meta. No prefácio do livro L'Amèr de Nicole Brossard, por exemplo, a tradutora Barbara 
Godard explica jogos de palavras envolvendo o "e" mudo do francês - como o seu apagamento deliberado no neologismo "laboratoir" para expressar a ausência da mulher nas atividades científicas - que não puderam ser mantidos na língua inglesa (FLOTOW, 1991). No prefácio de Susanne de Lotbinière-Harwood para a sua tradução do livro Le Desert mauve, também de Nicole Brossard, a tradutora explica os seus neologismos em inglês criados para manter os de língua francesa do texto fonte, entre eles, a palavra "auther" como tradução da palavra "auteure", mencionada anteriormente (DÉPÊCHE, 2000). Ademais, as notas e prefácios das tradutoras feministas também são utilizados para explicar os intertextos presentes no texto fonte, de maneira que esses paratextos assumem um caráter, muitas vezes, didático.

Conforme coloca Flotow, é difícil identificar teorias específicas que tenham orientado ou que validem a abordagem feminista da tradução. Contudo, a autora aponta que o desgaste sofrido pela figura $\mathrm{dx}$ autorx e do texto fonte causado pelo pensamento pós-estruturalista e pelas teorias da desconstrução, principalmente aquelas oriundas do pensamento derrideano, a partir da década de 1970 certamente desempenharam um papel importante no surgimento de tal abordagem. Como coloca Flotow $(1991$, p.80) “[...] todo o projeto pós-estruturalista de questionar narrativas hegemônicas, desafiando verdades definitivas e explorando a relatividade no significante forçou a tradução a se tornar uma empreitada criativa", dando a tradutora “[...] o direito, até mesmo o dever de 'abusar' do texto fonte" (FLOTOW, 1991, p.80).

Uma segunda influência na tradução feminista apontada pela autora é obviamente a dos feminismos de segunda onda ${ }^{12}$, os quais dotaram as autoras e as

\footnotetext{
${ }^{12} \mathrm{O}$ movimento feminista costuma ser dividido em três ondas (GONÇALVES e PINTO, 2011). A primeira onda estende-se do final do século XIX ao final da Segunda Guerra Mundial e tinha como pautas principais o sufrágio universal, a reivindicação pela participação na vida pública e a ampliação das oportunidades de estudo e trabalho (CRUZ, 2017). A segunda onda inicia-se ao final dos anos 1960 e é marcada por uma forte produção acadêmica. Além de ampliar as lutas da primeira onda do feminismo incluindo questões como violência doméstica, direitos reprodutivos, sexualidade feminina etc. (GONÇALVES e PINTO, 2011). Já a terceira onda começa a surgir nos anos 1980, a partir do questionamento de alguns dos conceitos das ondas anteriores e fortalecida pelos questionamentos oriundos da Teoria Queer. Dentre eles, questionou-se a categoria "mulher" como um termo universalizante porque, por essa categoria não fazer recortes de classe, raça, sexualidade etc., as pautas do feminismo de segunda onda centravam-se nas reivindicações de mulheres brancas, heterossexuais, de classe média alta, etc., de forma que muitas mulheres não se viam representadas (GONÇALVES e PINTO, 2011). É importante ressaltar que recentemente essa divisão do movimento feminista em três ondas tem sio criticada por ser muito centrada na luta das mulheres europeias e norte-americanas. O direito ao voto, por exemplo, só foi conquistado na
} 
tradutoras feministas tanto de autoridade quanto meios de ignorá-la. Com isso, "as tradutoras feministas estão atacando em pelo menos duas direções ao mesmo tempo: no uso convencional da linguagem em si e em visões tradicionais de tradução" (FLOTOW, 1991, p.81).

O primeiro aspecto que chama a atenção na prática da tradução feminista, e que é de extrema relevância para a presente pesquisa, é a sua aparente incompatibilidade com as práticas hegemônicas que invisibilizam xs tradutorxs e que foram tão duramente criticadas por Venuti. De fato, apesar de não terem se influenciado mutuamente, pode-se enxergar alguns paralelos entra as teorias e práticas das tradutoras feministas e a Teoria da Invisibilidade do Tradutor. Ambas apontam o potencial da tradução como instrumento de libertação; ambas criticam o apagamento dx outrx, seja pela linguagem no caso das tradutoras feministas, seja por concepções hegemônicas de tradução no caso de Venuti; ambas criticam essas mesmas concepções hegemônicas, como os conceitos de "fidelidade" e "autoria"; e tanto a tradução feminista quanto a teoria de Venuti utilizam-se da visibilidade como ferramenta contra o apagamento, de forma que implicam que tradutorxs alinhadxs a qualquer uma dessas perspectivas não mais procurarão mascarar o seu trabalho.

\subsection{Tradução Queer}

A Tradução Queer compartilha de muitas dessas características, mas diferentemente da Teoria da Invisibilidade do Tradutor e da Tradução Feminista, que as compartilham coincidentemente, a Tradução Queer o faz devido a uma influência direta dessa última. Em seu artigo “"This is My Girlfriend Linda' Translating Queer Relationships in Film: a Case Study of the Subtitles for Gia and a Proposal for Developing the Field of Queer Translation Studies", Elizabeth Sara Lewis parte do pressuposto de que

Assim como xs defensorxs da tradução pós-colonial argumentaram que a tradução
pode e deve ser uma forma de devolver às culturas colonizadas a sua voz e lutar
contra a hegemonia de culturas colonizadoras, e defensorxs da tradução feminista
argumentaram que a tradução pode e deve ser uma forma de empoderar as
mulheres representando-as claramente na linguagem e combatendo a hegemonia
patriarcal, agora é necessário defender uma forma de tradução que dê a pessoas segunda onda em muitos países, entre eles o Brasil, e na terceira onda em países como a Arábia Saudita. 
queer uma maior visibilidade e as ajude em sua luta contra o poder subjugador da hegemonia [cis-]heteronormativa (LEWIS, 2010, p.3).

Através do estudo de caso de diferentes legendas de uma cena do filme Gia - Fama e Destruição, Lewis busca demonstrar como conteúdos LGBTQAI+ podem ser facilmente apagados em traduções e que tradutorxs precisam ser especialmente treinadxs, para que sejam capazes de identificá-los e prevenir que sejam perdidos ou transformados no ato da tradução, uma vez que

[...] personagens, na maioria dos textos, como as pessoas na vida quotidiana, são, geralmente presumidas [cis-]heterossexuais até que se provem queer, e umx tradutorx desatentx, inconsciente desse tipo de predisposição pessoal, pode, então, facilmente, apesar de não intencionalmente, transformar um elemento queer em um [cis-]heteronormativo (LEWIS, 2010, p.3).

Isso se dá devido à existência do que Judith Butler ([1990] 2016) denominou "matriz heteronormativa" e, mais recentemente, tem sido chamada de matriz cisheteronormativa. A fim de melhor explicar o funcionamento dessa matriz e as suas implicações para a tradução, é preciso voltar às raízes da formulação desse conceito.

\subsubsection{A matriz cis-heteronormativa}

Em sua obra Quando dizer é fazer: palavras e ação ([1962] 1990), escrita com base em uma série de palestras ministradas em Oxford (Reino Unido) entre 1951-1954 e em Harvard (EUA) em 1955, Austin suscita uma discussão acerca da possibilidade de a linguagem não apenas descrever o mundo, mas também de constituir-se como uma forma através da qual agimos sobre ele.

O filósofo britânico propõe a divisão dos enunciados em atos de fala constativos e atos de fala performativos, estabelecendo, inicialmente, uma clara distinção entre eles. Compõem o primeiro grupo os enunciados que descrevem algo e poderiam ser avaliados com base em seu "valor de verdade": uma frase como "Esse gato é branco", por exemplo, pode ser declarada verdadeira ou falsa, bastando que se olhe para o gato para constatar se é ou não branco. O segundo grupo é composto por enunciados como o exemplo clássico utilizado por Austin em suas conferências: "Eu os declaro marido e mulher!". Enunciados como esse não descrevem nada e, por isso não podem ser qualificados como verdadeiros ou 
falsos. Em vez disso, tais enunciados são responsáveis por realizar uma ação, no caso, a de casar duas pessoas. Austin propõe que atos de fala performativos, que não podem ser avaliados quanto ao seu "valor de verdade", o sejam por suas condições de felicidade. Segundo essas condições, que de modo geral envolvem ser ditos pela pessoa adequada, no momento adequado e nas circunstâncias adequadas, um ato de fala performativo poderia ser declarado bem-sucedido ou malsucedido, a depender de se essas condições foram ou não atendidas. Sendo assim, o ato de fala "Eu os declaro marido e mulher!", por exemplo, seria um ato de fala mal sucedido caso não fosse dito por uma autoridade religiosa ou um funcionário do cartório, para um casal heterossexual de comum acordo, ao final da cerimônia de casamento (LEWIS, 2017).

Austin, então, tenta subdividir a classe dos performativos; no entanto, ao reconhecer a existência de performativos implícitos, não é capaz de estabelecer critérios ou métodos definitivos para distinguir os atos de fala performativo dos constativos, o que o leva a abandonar essa tarefa e concluir que todo ato de fala pode ser performativo em alguma medida. Uma frase como "Está chovendo", por exemplo, segundo a distinção que Austin faz inicialmente, seria interpretada como um enunciado constativo: bastaria que se olhasse pela janela para verificar se é verdadeiro ou falso. Contudo, um enunciado do tipo também pode ter um efeito performativo. Ao ouvi-lo enquanto as roupas estão estendidas do lado de fora para secar, alguém pode correr para retirá-las do varal. Nesse caso, o enunciado "Está chovendo" foi interpretado como "Tire as roupas do varal", tendo, assim, um efeito claramente performativo.

Embora a teoria dos atos de fala performativos tenha representado, de fato, uma importante inovação ao fazer com que a linguagem como um modo de ação humana passasse a ser o foco central da pragmática (ALENCAR, 2015), não significa que ela não tenha sido também alvo de críticas por parte de alguns teóricos. Dentre esses, destaca-se Jacques Derrida, que em seu texto “Assinatura, acontecimento, contexto" ([1972] 1991), aponta alguns aspectos problemáticos na teoria de Austin, sendo os principais deles: o fato de Austin parecer considerar o contexto como algo bem delineado e concreto, o que Derrida desconstrói ao início de seu texto; Austin também considera que toda comunicação performativa está sujeita à intenção $\mathrm{dx}$ falante, desconsiderando que uma frase pode ter efeitos performativos não previstos por essx no momento da enunciação; não inclui em 
seus estudos os usos "não-sérios" ou "não-reais" da linguagem, como piadas e atos de fala produzidos durante peças de teatro etc., não levando em conta que tais atos de fala também podem ter efeitos performativos; Austin leva em consideração a possibilidade de fracasso do performativo, mas o faz sem considerar que esse mesmo fracasso seria uma condição do performativo.

No entanto, a crítica mais importante que Derrida faz diz respeito ao fato de Austin não ter considerado a importância que a repetição tem em determinar se um ato de fala será bem-sucedido ou não. Como coloca o autor, "a possibilidade de repetir e, pois, de identificar as marcas está implicada em todo código, faz deste uma grade comunicável, transmissível, decifrável, iterável por um terceiro, depois para todo usuário possível em geral" (DERRIDA, 1991, p.19). Com isso, o que dá a um enunciado performativo o poder de realizar algo não é apenas ser dito pela pessoa adequada no momento e circunstâncias adequadas, como sugeriu Austin; ele precisa também ser reconhecido pelxs falantes como algo que pertence a um modelo reiterável. Em outras palavras: o enunciado "Eu os declaro marido e mulher!" realiza o ato de casar duas pessoas não apenas por ser dito por uma autoridade religiosa ou funcionário de um cartório a um casal heterossexual de comum acordo, após os votos, mas também porque somos capazes de reconhecêlo como fazendo parte de um ritual histórico e reiterável de casamentos (LEWIS, 2016).

É a partir da teoria de atos de fala performativos de Austin e dessa ênfase dada a importância da repetição explorada por Derrida que Butler desenvolve a sua teoria da performatividade em sua obra Problemas de gênero: feminismo e subversão da identidade ([1990] 2016). Peguemos, a título de ilustração, a sua definição de gênero: "O gênero é a estilização repetida do corpo, um conjunto de atos repetidos no interior de uma estrutura reguladora altamente rígida, a qual se cristaliza no tempo para produzir a aparência de uma substância, de uma classe natural de ser" (BUTLER, 2016, p. 69, grifos meus). Para Butler, o gênero não é uma essência nem uma interpretação das características físicas do corpo, mas sim algo criado através de atos performativos. Partindo do colapso da distinção entre os atos de fala performativos e constativos, a autora argumenta que um enunciado como "É uma menina”, declarado por umx médicx no momento do nascimento, não seria um mero ato de fala constativo, mas também um ato de fala performativo, uma vez que, desse momento em diante, terá início uma série de 
processos de socialização culturalmente associados ao gênero feminino, a saber: ser incentivada a usar a cor rosa, saias e vestidos, brincar com bonecas, forninhos e panelas, usar maquiagem, depilar-se etc. Nessa perspectiva, "Uma menina não nasce menina, ela é 'meninificada' no momento do nascimento [...], com base em um ou uma profissional da saúde observar certo aspecto da sua anatomia [...] e enunciar seu 'sexo biológico"” (LEWIS, 2017, p. 165).

Se o gênero é performativo, constituído por uma série de atos, não poderiam ser considerados verdadeiros ou falsos, mas sim "uma sequência de atos repetidos que se enrijecem até adquirir a aparência de algo que sempre esteve ali o tempo todo" (SALIH, 2015, p. 94), de forma que se acredita estar diante de algo "natural". Todavia, esse gênero é uma cópia de uma cópia, que não pressupõe um original. Logo, tal naturalização demonstra o poder que a repetição dá aos atos de fala performativos, uma vez que torna invisíveis os processos através dos quais essa aparente naturalidade foi criada.

Conforme coloca Salih (2015, p.94), "se o gênero é um 'processo regulado de repetição' que se dá na linguagem [e atos performativos], então será possível repetir o nosso gênero diferentemente". Tal visão do gênero como performativo levou algumxs críticxs a acusarem Butler de uma representação voluntarista do gênero, como se tratasse o gênero como algo que o sujeito é capaz de escolher fazer de forma livre e consciente (LEWIS, 2012). Essas críticas, no entanto, ignoram o fato de que, para Butler, a performance não pode ser totalmente livre, uma vez que é realizada "no interior de uma estrutura reguladora altamente rígida”. O que nos leva, por fim, à matriz cis-heteronormativa.

Segundo essa matriz de inteligibilidade, a identidade de gênero de uma pessoa deve alinhar-se ao sexo ao qual foi designada no momento de seu nascimento, e essa pessoa deve sentir-se sexualmente atraída por pessoas do sexo "oposto"; ou seja, uma pessoa que foi designada como mulher deve identificar-se como tal e sentir-se sexualmente atraída por homens (LEWIS, 2017). A matriz cisheteronormativa não prevê possibilidades de performar o gênero que não se enquadrem no binário masculino/feminino, de maneira que pessoas que se identificam como não-binárias acabam marginalizadas. Entretanto, essas pessoas podem ser, ao mesmo tempo, particularmente transgressoras, uma vez que “identidades que não estejam incorporadas na trama da matriz cultural passam a ser subversivas e constituem-se nas resistências móveis, transitórias, que 
atravessam os sujeitos e os transformam” (PADILHA; PALMA, 2017, p.2). Ao não se caracterizarem de acordo com as normas vigentes na sociedade - seja por transitarem entre o masculino e o feminino, por considerarem-se ambos ou nenhum (PADILHA; PALMA, 2017) - pessoas que se identificam como nãobinárias questionam a cis-heteronormatividade que apresenta homens ou mulheres como as únicas possibilidades.

No entanto, subversões à matriz cis-heteronormativas não são livres de consequências. Sendo o gênero algo criado performativamente, ele não teria uma essência, mas assume uma aparência de naturalidade. Porém, como demonstra a citação da obra de Butler destacada anteriormente, não basta que se realize um ato (de fala) performativo uma única vez para que o gênero seja criado; para tal, esses atos precisam ser repetidos continuamente, passando tais comportamentos de uma geração a outra, a ponto de naturalizarem-se. Uma vez que o processo performativo que naturaliza tais performances esconde o fato de que não existe um gênero original, acredita-se que o gênero é algo inato e cria-se um acordo tácito de exercê-lo e sustentá-lo. Consequentemente, espera-se que os indivíduos desempenhem os papéis de gênero que lhes são designados pela matriz cisheteronormativa, sendo que aqueles que não o fazem acabam por tornarem-se ininteligíveis ou vistos como menos humanos pelo restante da sociedade; ou, como coloca Butler,

\begin{abstract}
A marca do gênero parece "qualificar" os corpos como corpos humanos; o bebê se humaniza no momento em que a pergunta "menino ou menina?" é respondida. As imagens corporais que não se encaixam em nenhum desses gêneros ficam fora do humano, constituem a rigor o domínio do desumanizado e do abjeto, em contraposição ao qual o próprio humano se estabelece (2016, p. 193-194).
\end{abstract}

Diversos discursos ideológicos sustentam essa matriz cis-heteronormativa: concepções de sexo "biológico natural", a "naturalidade" da heterossexualidade reprodutiva, discursos sobre a família tradicional e "amor romântico", a ideia de que as mulheres são naturalmente submissas e os homens naturalmente dominantes etc. (LEWIS, 2016). Através desses discursos normatizadores, são construídas práticas reguladoras legitimadas por uma matriz de normas que impõem um desejo heterossexual e não admitem identidades de gênero que não estejam de acordo com o binário masculino/feminino (PADILHA; PALMA, 2017). Resulta disso que essas pessoas, geralmente, sofrem algum tipo de punição. 


\subsubsection{Implicações da matriz cis-heteronormativa para a tradução}

Os efeitos mais óbvios da matriz cis-heteronormativa para a tradução podem ser observados nos casos de censura direta, por ser justamente aquilo que orienta os discursos associados à "ideologia de gênero" em sua concepção pejorativa atual segundo propagada pelos setores mais conservadores da sociedade; isto é, como “[...] um movimento social permissivo pró-aborto e pró-LGBT[QAI+] que deveria ser combatido em nome da defesa da família e do bem-estar das crianças" (GARRAIO; TOLDY, 2020, p.133). Discursos anacrônicos desse tipo são frequentemente utilizados para inflamar um pânico moral: qualquer avanço em direção à igualdade de gênero ou à garantia de direitos de pessoas LGBTQAI+ é vista como uma ameaça aos valores morais da sociedade e utilizado para justificar medidas de controle, como a censura de textos nos quais estão presentes conteúdos LGBTQAI+ em países autoritários; ou até mesmo tentativas de impedir que tópicos relacionados a esses conteúdos sejam discutidos em sala de aula (basta vermos os projetos de lei "Escola Sem Partido" ou o absurdo "kit gay").

Quando não é responsável por censuras diretas, a matriz cisheteronormativa pode, muitas vezes, levar a autocensuras por parte dxs tradutorxs. Segundo José Santaemilia, “[...] em todas as circunstâncias históricas, tradutorxs tendem a censurar a si mesmxs - voluntária ou involuntáriamente - de forma a produzir reescritas que sejam 'aceitáveis' de uma perspectiva tanto social quanto pessoal” (2008, p.222). Quanto à perspectiva pessoal, umx tradutorx que se depare com um texto como Houseki no Kuni pode optar por apagar deliberadamente a não-binariedade de gênero dxs personagens por não ser capaz de conceber ou aceitar identidades de gênero que não se alinhem à matriz cisheteronormativa. Já em relação à perspectiva social, como vimos, essa matriz é uma "estrutura reguladora altamente rígida" que compõe "[...] um conjunto complexo de pressões, expectativas e restrições sociais e institucionais [...]" (LEWIS, 2017, p.175-176). Sendo assim, é de se esperar que aquelxs que não se adequam a ela ou que tentem subvertê-la de alguma maneira enfrentem algum tipo de reação negativa, principalmente por parte de setores mais conservadores da sociedade ${ }^{13}$. Umx tradutorx que empregue uma linguagem inclusiva para

\footnotetext{
${ }^{13}$ Para um exemplo concreto, basta lembrar o caso recente do quadrinho d' Os Vingadores que o então prefeito do Rio de Janeiro, Marcelo Crivella, tentou, sem sucesso, censurar por conter uma imagem de beijo gay entre duas personagens do sexo masculino.
} 
visibilizar identidades trans ou não-binárias pode ter o seu trabalho bem recebido dentro da comunidade LGBTQAI+, porém, ser duramente criticado pelos demais setores da população. Sua tradução pode ser acusada de tentar promover a “ideologia de gênero", a editora pode recusar-se a publicá-la para evitar uma possível repercussão negativa, $x$ tradutorx pode vir a perder o seu emprego ou trabalhos futuros etc. Umx tradutorx ciente desse cenário pode optar por se autocensurar, apagando ou minimizando conteúdos LGBTQAI+ para que suas traduções sejam bem recebidas pelo público leitor.

Os efeitos da matriz cis-heteronormativa para a tradução podem se manifestar de maneiras mais sutis. Por ser também uma matriz de inteligibilidade a partir da qual interpretamos o mundo (LEWIS, 2017), isto é, adequar-se a ela é visto como a norma, enquanto não se adequar é visto como desviante, ao conhecermos alguém (ou nos depararmos com uma personagem nova em uma obra) presumimos que essa pessoa seja heterossexual e cisgênera até que nos seja comprovado o contrário. Em relação à obra analisada na presente pesquisa especificamente, pode-se notar essa tendência em interpretar xs personagens com base na matriz cis-heteronormativa no discurso sobre elxs. A seleção de excertos a seguir é oriunda de um fórum de discussão no site myanimelist.com ${ }^{14}$ no qual se discutia os pronomes que deveriam ser utilizados para referir-se axs gemas:

Ugh! Eu não aguento mais com o "ele"”e "dele".[...] Eu sei que elas não têm gênero. Mas qual é, pessoal, nós temos um personagem masculino (Sensei), as gemas parecem $100 \%$ femininas. E o fato de as roupas delas também serem assim deveria ser óbvio ou alguém acha que o Sensei é gay? Sensei é hetero, as roupas e vestidos de noiva deveriam ter feito sentido agora para as pessoas agora. Japonês usando o pronome de gênero não significa nada, é apenas uma escolha primária para personagens sem gênero e algumas ambíguas (Lairucrem, 28/11/2017).

Obviamente, todas elas têm atributos sexuais femininos. Elas não têm cérebro ou rins e todos nós as consideramos pessoas. Por quê? Porque elas se parecem com pessoas. Da mesma forma, elas não têm órgãos genitais nem seios, mas se parecem com mulheres, então devemos fazer a mesma abstração e considerá-las do sexo feminino (mruize85, 28/11/2017).

\footnotetext{
${ }^{14}$ Disponível no link: https://myanimelist.net/forum/?topicid=1687221.
} 
Elas parecem femininas para todos os efeitos, então referir-se a elas como tal faz mais sentido. As pessoas estão apenas tentando forçar políticas identitárias nisso (Saint_Nepunepu, 28/11/2017).

Pessoalmente, todas elas simplesmente parecem femininas para mim, até a Bort ou a antarc etc. que as pessoas citam como masculinas. Eu provavelmente vou usar pronomes femininos sempre (Lanz, 28/11/2017).

É interessante notar que o debate se inicia com o descontentamento dx autorx do tópico de discussão com o uso de pronomes masculinos para se referir axs personagens não pelo fato de isso eliminar a não-binariedade de gênero dessxs, mas pelo fato de acreditar que pronomes femininos deveriam ser utilizados porque “as gemas parecem 100\% femininas". Apesar de reconhecer que xs personagens não têm gênero, a sua percepção delxs como femininas é motivo suficiente para generificá-lxs. Esse sentimento é compartilhado por usuárixs que responderam ax autorx, para xs quais se xs personagens parecem mulheres, "devemos [...] considerá-las do sexo feminino", ou "referir-se a elas como tal faz mais sentido". Pode-se notar as influências de ideologias cis-heteronormativa na argumentação utilizada para fundamentar o ponto de vista expressado nessas respostas, como as roupas dxs personagens, que são interpretadas como femininas, ou o que percebem como "atributos sexuais femininos" - apesar de não ficar muito claro quais seriam exatamente esses atributos, já que, como aponta x próprix autorx dessa resposta, "as personagens não têm órgãos genitais nem seios".

Conforme mencionado anteriormente, nossas predisposições podem nos levar a interpretar personagens como cis-heterossexuais até que se prove o contrário, ou até mesmo em casos em que é explicitado que essxs personagens não se conformam à matriz cis-heteronormativa, como demonstram os comentários acima. Dessa forma, pode-se afirmar que ideologias cis-heteronormativas exercem uma grande influência na forma como interpretamos uma obra; o que, por sua vez, pode fazer com que tradutorxs acabem por apagar conteúdos LGBTQAI+ do texto devido a uma interpretação equivocada do texto fonte. Sendo assim,

mesmo quando o conteúdo homoerótico de textos queer não é abertamente censurado, ele é frequentemente perdido na tradução devido a problemas como o favorecimento de elementos e fraseio [cis-]heteronormativos em detrimento dos queer para melhorar a fluência ou uma simples falta de uma leitura cuidadosa causada por uma predisposição [cis-] heteronormativa (LEWIS, 2010, p.3, grifo meu). 
Nota-se aqui, também, um paralelo entre a teoria da Invisibilidade do Tradutor e a Tradução Queer. O predomínio da fluência nas traduções, muitas vezes, pode desempenhar um papel no apagamento de conteúdos LGBTQAI+. Ao deparar-se com um problema de tradução causado pela sua presença que $\mathrm{x}$ force a escolher entre mantê-lo ou comprometer a fluência do texto meta, dificilmente umx tradutorx escolherá a primeira opção. Traduzir uma obra na qual estão presentes personagens não-binárixs como Houseki no kuni para línguas neolatinas, por exemplo, requer o uso de estratégias que certamente causarão estranhamento nxs leitorxs para que a não-binariedade de gênero dxs personagens seja mantida.

Percebe-se, então, que a cis-heteronormatividade pode levar ao apagamento de identidades e conteúdos LGBTQAI+ de diferentes meneiras, seja por censura direta, por autocensuras motivadas por um desejo de produzir uma tradução que esteja de acordo com os valores da sociedade na qual x tradutorx encontra-se inseridx, seja por uma leitura equivocada provocada por uma predisposição cisheteronormativa. Logo,

[...] seria necessário examinar questões como de que maneira a censura acidental de elementos queer ocorreram porque tradutorxs operando no interior da matriz [cis-]heteronormativa presumem que personagens sejam heterossexuais [e cisgêneras] e como a censura deliberada de elementos queer por tradutorxs, editorxs e governantes ocorrem devido a fatores como homofobia (ou queer-fobia) ou medo de que textos queer não sejam comercializáveis a um público [cis]heteronormativo. Pode-se examinar também como a queer-fobia também leva à inserção de elementos anti-queer em traduções que não estavam presentes no texto fonte (LEWIS, 2010, p.8).

Entretanto o fato de estarmos inseridxs na matriz cis-heteronormativa não significa que devamos, necessariamente, reproduzí-la.

\subsubsection{Tradução Queer e a possibilidade de mudança na matriz cis- heteronormativa}

Conforme coloca Lewis, "[...] nas teorizações sobre a matriz [cis]heteronormativa de Butler os seres humanos não estão totalmente sujeitados e subordinados ao discurso e ao poder" (2017, p.177, grifo da autora). Para Butler, o mesmo mecanismo performativo responsável pelo processo de consolidação da matriz é justamente aquilo que permite que seja subvertida. Se entendemos que o 
gênero é uma repetição estilizada de atos que se consolida através do tempo, então, presume-se que seja possível que novas ideias, discursos, práticas etc. sejam inseridas; e, a partir do momento em que essas repetições subversivas enraizam-se e proliferam-se, uma eventual mudança na matriz pode vir a tomar forma. Em outras palavras, "a tarefa não consiste em repetir ou não, mas em como repetir ou, a rigor, repetir e, por meio de uma proliferação radical do gênero, afastar as normas do gênero que facultam a própria repetição" (BUTLER, [1990] 2016, p.255, grifo da autora).

De que maneiras, então, a Tradução Queer poderia contribuir para desestabilizar ou subverter a matriz cis-heteronormativa? Em artigo publicado em 2012, Luise Von Flotow analisa as conquistas históricas dos feminismos na tradução, assim como novos direcionamentos acadêmicos que têm surgido no campo. A autora aponta a Teoria Queer como um possível caminho para o desenvolvimento dos Estudos da Tradução, citando a pertinência do aspecto sociocrítico e ativista que fundamentam as ideias em torno da performatividade. Toda tradução já é, em si, uma repetição diferente: o próprio ato de traduzir já faz com que um texto escrito e publicado em um dado contexto e para um público específico seja inserido em um novo contexto, onde ele irá, inevitavelmente, adquirir um novo significado. Peguemos, por exemplo, o mangá analisado na presente pesquisa. Em sua cultura fonte, a obra não procura discutir questões relacionadas a gênero e sexualidade: o fato de xs personagens não terem um gênero especificado é apenas uma consequência natural da premissa imaginada pela autora. Em vez disso, esse aspecto da obra fica em segundo plano, sendo trazido à tona apenas esporadicamente. Considerando que representações de relacionamentos homoafetivos e fluidez de gênero são comuns em mangás (DARLINGTON \& COOPER, 2010), uma obra como Houseki no kuni, em que o gênero não é o seu tema central, não se destacaria nesse sentido em seu país de origem. Ao ser trazido para o Ocidente, contudo, o gênero dxs personagens assume uma posição central e passa a figurar nas discussões acerca do mangá, sendo o tema de publicações em blogs (ver KAISER, 2017a; 2017b; VILLANUEVA, 2018), além de tópicos de discussão em fóruns ${ }^{15}$.

\footnotetext{
${ }^{15}$ Para mencionar alguns: https://www.reddit.com/r/LandoftheLustrous/comments/deewdx/increased_hnk_popularity_among trans and enby/;
} 
Nessas discussões, questiona-se as identidades de gênero dxs personagens; as formas mais adequadas de referir-se a elxs; colocam-se em xeque ideologias de linguagem, como o uso do masculino genérico e, apesar de discursos cisheteronormativos serem reproduzidos (ver seção 2.3.2), esses mesmos discursos são, também, questionados e desconstruídos. O fato de a tradução de um texto com conteúdo LGBTQAI+ ter suscitado tais discussões aponta para o potencial que a Tradução Queer tem de subverter a hegemonia cis-heteronormativa. A mera inserção de uma obra na qual estão presentes personagens não-binárixs em um contexto no qual são praticamente inexistentes bastou para iniciar debates em torno da identidade de gênero e, potencialmente, desestabilizar a matriz cisheteronormativa.

No entanto, não basta apenas traduzir textos nos quais figuram conteúdos LGBTQAI+, é preciso que esses elementos sejam visibilizados na tradução. Conforme assinala Flotow, uma abordagem queer para a tradução pode ser útil pois

Não apenas a escolha dos textos pode ser feita de um ponto de vista sócio-crítico, mas a tradução em si pode refletir e chamar atenção a aspectos do texto fonte que são novos, ou inovadores, ou considerados úteis ao novo público leitor. [...] Pode funcionar tanto para criticar e informar; pode revelar abusos, mas também atrair uma atenção exagerada a aspectos desejáveis dos textos. É parte de uma luta contínua para "fazer coisas com palavras" (2012, p.134, grifos da autora).

Com isso, chegamos à proposta de Lewis para lidar com a tradução desses conteúdos. Considerando o objetivo da Tradução Queer de “[...] contestar a hegemonia [cis-] heteronormativa de modo a dar voz e uma maior visibilidade a pessoas queer" (LEWIS, 2010, p.11), a autora propõe adaptar as táticas tradutórias da tradução feminista como forma de visibilizar identidades LGBTQAI+ e expor as ideologias e os mecanismos responsáveis por sua marginalização. Com isso, enquanto a escrita de paratextos como prefácios, notas de tradutora e posfácios na tradução feminista servia para explicar decisões tradutórias tomadas ou jogos de palavras que não puderam ser traduzidos devido às diferenças entre a língua fonte e a língua meta, na Tradução Queer, os mesmos paratextos serviriam para visibilizar o conteúdo LGBTQAI+ do texto fonte, dificuldades envolvidas em sua

https://myanimelist.net/forum/?topicid=1687221;

https://www.reddit.com/r/ennnnnnnnnnnnbbbbbby/comments/bs7012/binary representation in lan d of the lustrous/, 
manutenção, assim como as estratégias empregadas para mantê-lo (ou uma explicação acerca das motivações que levaram ao seu apagamento nos casos em que não foi possível). A tradução alemã do mangá Houseki no kuni nos fornece um ótimo exemplo de um paratexto do tipo. Devido à natureza gramatical do gênero da língua alemã, optou-se por utilizar uma linguagem inclusiva para manter a não-binariedade de gênero dxs personagens. $O$ posfácio da edição apresenta uma exposição do conteúdo LGBTQAI+ do texto fonte seguido de uma brevíssima entrevista com a tradutora do mangá na qual ela fala um pouco sobre as dificuldades em lidar com ele. Segue-se a isso um quadro resumindo como funciona a linguagem inclusiva utilizada para que $\mathrm{x}$ leitorx possa compreender $\mathrm{o}$ texto. $O$ posfácio é finalizado com uma reafirmação da não-binariedade de gênero dxs personagens, a importância de mantê-la para visibilizar identidades nãobinárias e um link para a página da ativista responsável pela criação da linguagem inclusiva empregada para aquelxs que se interessarem em saber mais a respeito.

Já a tática de complementação seria utilizada tanto para compensar pelas diferenças entre línguas quanto para visibilizar os conteúdos LGBTQAI+ da obra e criticar ideologias e usos cis-heteronormativos da linguagem que podem contribuir para a marginalização dessas pessoas. Nesse sentido, o emprego de uma linguagem inclusiva de algum tipo em traduções para línguas gramaticalmente generificadas pode ser considerado uma tática de complementação, pois esse tipo de linguagem não apenas visibiliza as identidades não-binárias dxs personagens, como também serve para expor e criticar a natureza binária do gênero gramatical.

Por fim, na prática de hijacking, x tradutorx "corrigiria" um texto por motivos políticos, eliminando termos LGBTfóbicos ou substituindo usos cisheteronormativos de linguagem por usos mais inclusivos, mesmo que o texto fonte não tenha a intenção de subverter a matriz cis-heteronormativa. $\mathrm{O}$ caso de traduções do mangá Houseki no kuni para línguas gramaticalmente generificadas é bastante interessante nesse sentido. Devido ao fato de que, como mencionado anteriormente, o texto fonte não se propõe a discutir identidades de gênero e à relação intrínseca que há entre as linguagens inclusivas e políticas identitárias, qualquer tentativa de não designar um gênero axs personagens nessas línguas irá, necessariamente, infundir ao texto meta um caráter político onde antes não havia nenhum. Dessa forma, o emprego da tática de complementação nesses casos 
provavelmente seria interpretado pelxs leitorxs como um caso de hijacking e estaria sujeito à reação negativa que essa tática costuma enfrentar.

Sendo assim, há três maneiras nas quais a Tradução Queer pode contribuir para subverter a matriz cis-heteronormativa. A primeira delas seria a partir da própria escolha dos textos que serão traduzidos. A inserção de textos dos quais temáticas ou personagens LGBTQAI+ fazem parte pode servir para ampliar a representatividade desses indivíduos na cultura meta e iniciar discussões sobre esses temas em comunidades onde antes isso não era debatido. Nesse sentido, os mangás são particularmente relevantes devido à vasta gama de performances de gênero e sexualidade que essa mídia oferece e à disponibilidade de obras voltadas para os mais variados públicos.

A segunda maneira diz respeito às estratégias adotadas para lidar com o texto a ser traduzido em si. De acordo com a proposta de Lewis, a Tradução Queer preocupa-se em não apenas manter os conteúdos LGBTQAI+, mas também enfatizá-los de forma a visibilizar pessoas marginalizadas pela matriz cisheteronormativa e servir como uma forma de resistência.

A terceira maneira diz respeito ao seu aspecto teórico e sóciocrítico. A Tradução Queer, conforme propõe Lewis, busca explorar tanto as formas nas quais a tradução pode contribuir para reforçar a matriz cis-heteronormativa quanto o seu potencial de subvertê-la. Com esse objetivo em mente, segundo a autora, seriam estudados quais textos onde estão presentes conteúdos LGBTQAI+ têm sido traduzidos para quais línguas com o intuito de averiguar de que maneiras a disponibilidade desses textos traduzidos pode ter influenciado a construção de comunidades LGBTQAI+ e a sua aceitação ou rejeição. Também seriam estudadxs quem seriam xs tradutorxs desses textos: suas vidas e seus trabalhos, se a sua sexualidade exerceu alguma influência na maneira como traduzem etc. Também seriam estudadas as formas como os textos foram traduzidos: se os conteúdos LGBTQAI+ foram apagados nas traduções, se esses foram enfatizados em textos nos quais não eram muito explícitos e se xs tradutorxs se utilizaram de paratextos para anunciar o seu projeto tradutório e visibilizar as suas intenções.

A partir disso, proponho que a Tradução Queer deve servir ao propósito de olhar criticamente para as traduções desses textos e se perguntar: de que maneiras a tradução contribui para a construção de sujeitos marginalizados? Com isso, deve-se problematizar as ideologias cis-heteronormativas que subjazem às 
estratégias tradutórias adotadas; as maneiras como essas reproduzem ideologias e usos cis-heteronormativos de linguagem; o papel que as ideologias hegemônicas de tradução exercem sobre o apagamento de identidades e conteúdos LGBTQAI+ em traduções; e, mais importante, como tudo isso pode contribuir para reforçar a matriz cis-heteronormativa e o que pode ser feito para que a tradução a subverta.

Todas as abordagens tradutórias abordadas no presente capítulo têm em comum o fato de utilizarem a visibilidade como forma de resistência: xs tradutorxs precisam fazer-se visíveis ao empregá-las e, muitas vezes, é necessário que comprometam a fluidez das traduções, de maneira que não são compatíveis com a abordagem domesticadora apontada por Venuti. Logo, é de se esperar que traduções que empregam essas táticas não sejam bem recebidas pelo público leitor. Não pretendo, com a presente pesquisa, defender que traduções que adotem esse viés são melhores que aquelas que não o fazem, tampouco pregar que todx tradutorx deve necessariamente utilizar as táticas da Tradução Queer para lidar com conteúdos LGBTQAI+, até porque sabe-se que a prática tradutória está sujeita a uma série de normas e restrições (TOURY, 1995) que dificultam o seu uso mesmo nos casos em que xs tradutorxs têm o desejo de empregá-las. Contudo, pretendo argumentar em favor desse tipo de tradução, uma vez que apenas manter esses conteúdos presentes no texto fonte sem enfatizá-los em alguma medida pode não ser suficiente para combater o apagamento de identidades LGBTQAI+ em traduções.

Com essas considerações em mente, passarei a seguir às análises das traduções do mangá Houseki no kuni. 


\section{Análise}

Iniciarei a análise dos dados com as traduções amadoras para o português, inglês e espanhol; e partirei para as traduções profissionais em seguida. Para a análise da tradução amadora para o português, optei por utilizar a tradução feita pelo grupo Dispersion Translations, disponível no site https://dispersiontl.blogspot.com/, e traduzida por Samoro (é comum na prática de scanlation que xs tradutorxs adotem pseudônimos, visto que se trata de uma prática ilegal, do ponto de vista jurídico ${ }^{16}$ (ARAGÃO, 2016). Os dados analisados são compostos tanto pelos textos traduzidos quanto por informações paratextuais que acompanham as traduções e informações metatextuais coletadas de publicações da própria tradutora no blog do grupo. O mesmo não será feito com as traduções amadoras para o inglês e para o espanhol pois, no caso da primeira, as traduções são feitas de forma completamente anônima, não sendo fornecido sequer um pseudônimo na maioria dos capítulos ${ }^{17}$, ou, nos casos em que esses são fornecidos, não são apresentadas informações sobre um grupo de tradução, de forma que não pude encontrar uma página específica contendo mais informações. No caso da tradução amadora para o espanhol, existia uma página do grupo de tradução na internet, porém, eles perderam o domínio antes do início da presente pesquisa e foram forçados a migrar para um grupo no site discord.com, onde não são fornecidas informações sobre as traduções, apenas o seu link para download. Por esses motivos, os dados para a análise das traduções amadoras para o inglês e o espanhol foram coletados em sites agregadores, sendo eles https://manganelo.com/ e http://es.ninemanga.com respectivamente.

\subsection{Tradução amadora para o português}

Para a maior parte dos capítulos, a tradução amadora para o português não disponibilizou nenhum tipo de paratexto contendo informações sobre as estratégias tradutórias empregadas para lidar com a não-binariedade de gênero dxs personagens, de forma que essas precisariam ser inferidas a partir da análise

\footnotetext{
${ }^{16}$ A prática, contudo, é tolerada pela indústria por não possuir fins lucrativos e por funcionar como uma espécie de pesquisa de mercado, onde as editoras podem verificar quais obras são populares antes de comprar os direitos de distribuição (ARAGÃO, 2016).

${ }^{17} \mathrm{Na}$ tradução amadora para o inglês, os capítulos não são sempre traduzidos pelas mesmas pessoas.
} 
microtextual. No entanto, esse quadro muda com a publicação da tradução do capítulo 80 , a qual vem acompanhada da nota da tradutora reproduzida abaixo.

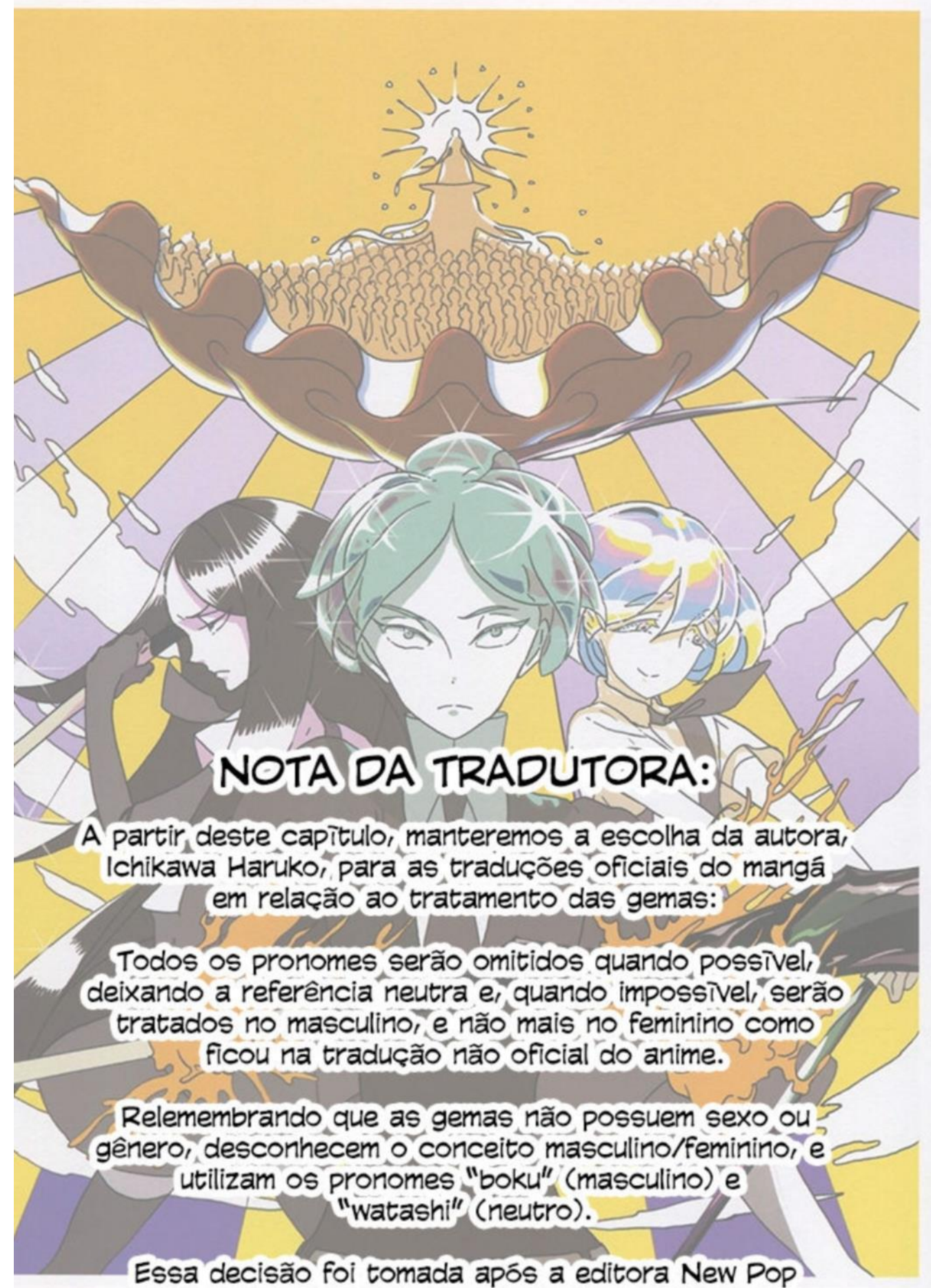
anunciar que o mangá será publicado por eles, ainda sem uma data determinada. Apoiem a autora e comprem a versão deles quando sair. -Samoro 
A nota nos fornece algumas informações acerca das decisões tradutórias tomadas, como o uso que era feito do feminino para referir-se axs gemas e o uso que se fará de formas neutras "quando possível" e do masculino "quando impossível" desse capítulo em diante. A nota também oferece algumas informações acerca da motivação por trás da mudança de estratégia, sendo ela uma vontade de manter a escolha da autora do mangá motivada pelo anúncio da editora NewPop.

Apesar disso, há algumas informações relevantes que não podem ser extraídas da nota acima, como o que motivou o uso do feminino nos capítulos anteriores, e o porquê de o anúncio da editora ter acarretado a mudança de estratégia. Felizmente a tradutora elabora o conteúdo da nota em uma publicação no blog do grupo de tradução, conforme reproduzido abaixo ${ }^{18}$ (SAMORO, 15/072019):

\begin{tabular}{|l|l|}
001 & Avisos e Alterações sobre Houseki no Kuni \\
002 & Posted by: Samoro \\
003 & Salve pessoas! Samoro aqui!! \\
004 & Após o um mês de hiato da autora, Houseki no Kuni ganhou seu \\
005 & capítulo novo este mês. Então se preparem para terem seus corações \\
006 & partidos mais um pouco, porque pelo o que eu vi das imagens \\
007 & oficiais...É triste! \\
008 & Agora vamos ao que interessa, que são as alterações que farei a partir \\
009 & de agora no mangá: \\
010 & Muitos leitores vieram por causa do anime legendado, que saiu antes \\
011 & de eu pegar o projeto com o Howard (editor). Nas legendas, as gemas \\
012 & são tratadas com pronomes femininos, porque todas aparentam ser \\
013 & meninas ou agem como meninas. E por isso eu e o How decidimos \\
014 & manter a tradução “feminina", deixando claro na página de \\
015 & apresentação que as gemas não tem gênero definido: são assexuados e \\
016 & agêneros. Não existe meninos e meninas, apenas gemas. Por causa \\
018 & dessa não-binariedade coloquei Antarcticita e Cairngorm usando \\
019 & pronomes masculinos/neutros, o mesmo fiz quando se referiam ao \\
020 & grupo no plural. Infelizmente quem legendou parece não ter se \\
021 & aprofundado muito em alguns termos da gemologia e mantiveram \\
022 & muitas coisas em inglês :
\end{tabular}

${ }^{18}$ Para evitar o uso do "[sic]" todas as vezes em que houver um desvio da norma padrão, deixo claro que os textos da tradutora foram reproduzidos aqui exatamente da maneira como aparecem no site. 
023 Recentemente a New Pop anunciou no Anime Friends no Rio de 024 Janeiro que eles lançarão o mangá, seguindo o modelo japonês com as 025 possíveis capas holográficas (preparem seus dinheiros \$\$), mas ainda 026 sem uma previsão de data. Por conta disso fui pesquisar um pouco 027 mais a fundo sobre os lançamentos oficiais do mangá e do anime em 028 outros países, por causa da questão pronominal. Em um site ${ }^{19}$, descobri 029 que a escolha da neutralidade dos pronomes É DA AUTORA, da 030 própria Ichkawa, então isso deve ser mantido em todos os lugares em 031 que ele for lançado. Na França, os personagens usam pronomes 032 masculinos como na versão japonesa (Fos usa boku para referir-se, 033 Rutilo usa watashi, ninguém usa atashi), enquanto na versão em inglês 034 os pronomes foram omitidos, usando os próprios nomes. Os nomes das 035 pedras devem vir traduzidos SIM, como é oficialmente em espanhol:

036 (se tem o nome em português pra quer deixar em inglês?)

037 A partir desses ocorridos e manter uma maior fidelidade da série 038 passarei a manter a neutralidade dos personagens e tentar omitir os 039 pronomes quando possível, e caso não dê, será utilizado o masculino 040 para referirem-se. Já peço desculpas pelos possíveis transtornos de 041 leitura e estranhamento que serão causados nos leitores ao não verem 042 mais as gemas se referindo como ela/elas.

043 (e quem conseguir comprar o mangá quando sair, comprem para 044 apoiar a autora)

O texto inicia-se com um brevíssimo aviso sobre o que esperar do próximo capítulo antes de seguir "ao que interessa”, que são as mudanças que serão feitas na tradução com relação ao tratamento dado ao gênero dxs personagens. Nesse pequeno texto é explicado o que motivou a decisão de utilizar o feminino para referir-se à maioria delxs assim como o que motivou as alterações que passariam a integrar a tradução daquele momento em diante.

Em seu texto, pode-se ver claramente como as predisposições cisheteronormativas motivaram o apagamento das identidades não-binárias dxs personagens do mangá. Apesar de reconhecer que elxs são "assexuados e agêneros", não havendo, assim, "meninas ou meninos, apenas gemas", a tradutora não pode evitar associar-lhes o gênero feminino, pois essxs "aparentam ser meninas ou agem como meninas". O mesmo aplica-se ao uso do masculino para referir-se axs personagens Antarticita e Cairngorm: apesar de não ser explicitado

\footnotetext{
${ }^{19}$ No texto fonte, a palavra "site" contém um hiperlink que direciona o leitor para a página "https://lanaveinvisible.com/2018/03/10/las-piedras-del-paraiso-de-haruko-ichikawa-houseki-nokuni/".
} 
no texto, ambxs xs personagens apresentam estilizações corporais e traços de personalidade mais comumente associados aos homens, o que pode levar à sua interpretação como masculinxs ou andróginxs. Com isso, o texto também reforça estereótipos de gênero ao insinuar que é possível identificar o gênero de alguém apenas a partir de sua estilização corporal ou comportamento, sem considerar que há diversas maneiras de expressar o gênero e a sexualidade que não se conformam às expectativas que a matriz cis-heteronormativa nos impõe. Esses exemplos apontam para a tendência dos indivíduos de presumir que pessoas e personagens alinham-se à matriz cis-heteronormativa até que seja provado o contrário, ou no caso, mesmo depois de provado o contrário. Com base apenas na aparência e na personalidade dxs gemas atribuiu-se um gênero a elxs, apesar de serem nãobinárixs.

A tradutora dá prosseguimento ao seu texto explicando o que motivou a mudança na forma de lidar com o gênero dxs personagens, a saber, o anúncio de que a editora NewPop publicará o mangá no Brasil e a sua subsequente pesquisa sobre o uso dos pronomes em publicações oficiais de Houseki no kuni. O aspecto que mais chama a atenção nesse trecho é a ênfase dada ao fato de que manter a não-binariedade de gênero dxs personagens é algo que parte da própria autora conforme sugerem o uso de negrito e caixa alta em "É DA AUTORA" e a subsequente reiteração em "da própria Ichikawa" - e que, por conta disso, deve ser mantida nas traduções. Todos esses fatores levaram a tradutora a adotar o que considera ser uma tradução de "maior fidelidade" ao omitir os pronomes quando possível e utilizar o masculino quando não for.

Aqui podemos ver como algumas ideologias sobre tradução influenciam a forma como o texto será traduzido. A primeira delas diz respeito à primazia da autoria já apontada por Venuti: para a tradutora, devido ao fato de que manter a não-binariedade de gênero dxs personagens é uma escolha da autora, essa "deve ser mantida em todos os lugares em que [o mangá] for lançado". Isso nos leva à segunda ideologia sobre tradução, relativa à noção de fidelidade: devido ao fato de ser um desejo da própria autora que um gênero não seja atribuído axs gemas, a tradutora considera mais fiel uma tradução que respeite tal desejo. Nesse caso em questão, essa preocupação com a fidelidade é algo que favorece a manutenção da não-binariedade de gênero, já que levou a um esforço para evitar formas generificadas (embora não seja sempre o caso, conforme sugere a indicação de 
que o masculino será utilizado quando não for possível manter a referência neutra); porém, como veremos na análise da tradução amadora para o inglês mais adiante, um argumento semelhante é utilizado para justificar o apagamento das identidades não-binárias dxs personagens.

Um último ponto de interesse na publicação da tradutora é a insinuação de que nem sempre é possível manter a referência neutra. Isso, obviamente, diz respeito ao fato de a língua portuguesa ser gramaticalmente generificada e sem uma opção de gênero neutro oficialmente reconhecida, o que faz com que seja impossível manter a não-binariedade de gênero dxs gemas respeitando a norma padrão da língua. O que se destaca no texto é o fato de que, apesar de ser reconhecido que xs personagens não têm um gênero e que manter essa característica é um desejo da própria autora, a tradutora parece não ter cogitado o uso de algum tipo de linguagem inclusiva para referir-se axs gemas. Isso pode estar relacionado a duas possíveis ideologias, uma de tradução e uma de linguagem. Quanto à ideologia de tradução, conforme mencionado anteriormente, traduções são avaliadas a partir de um critério de fluência que exige que xs tradutorxs mascarem o seu trabalho e criem a ilusão de que aquilo que se lê não é uma tradução, mas sim o texto fonte. Sendo assim, o uso de uma linguagem inclusiva causaria um estranhamento nxs leitorxs que comprometeria a fluência do texto, levando a uma possível rejeição da tradução. Já em relação à ideologia de linguagem, é possível que a tradutora não tenha cogitado o uso de uma linguagem inclusiva em razão da grande rejeição que essa ainda sofre por não se conformar à norma padrão da língua portuguesa, ou pela sua associação à chamada "ideologia de gênero".

O último caso é o mais provável, pois, conforme coloca Jüngst (2015, p.50), “[...] fãs de mangás são altamente críticos das traduções de mangás, não importa se falam japonês ou não". Ao se deparar com uma tradução de mangás, essxs leitorxs esperam estar diante de algo que seja o mais próximo possível do texto fonte. Isso implica uma abordagem que preze pela equivalência formal da tradução, já que xs fãs "querem que seus mangás pareçam japoneses, e isso estende-se a alguns aspectos linguísticos assim como pictóricos" (JÜNGST, 2015, p.60). Por conta disso, é comum que muitas características do texto fonte sejam mantidas na tradução: o sentido de leitura permanece da direita para a esquerda; as onomatopeias não são modificadas, em vez disso, é acrescentada uma tradução do 
som que representa nas sarjetas ou no interior das vinhetas; e tende-se a manter os honoríficos (termos como "Sensei", "sama", “-kun", "-chan" etc.) e os nomes das personagens. De acordo com Jüngst (2015), a tradução que privilegia o aspecto formal dos mangás serve para desempenhar a função comunicativa de fazer com que xs leitorxs aparentem ser conhecedorxs de mangás, uma vez que outras funções comunicativas, como entretenimento, poderiam ser desempenhadas de formas satisfatórias se as imagens fossem invertidas para se conformarem ao sentido de leitura ocidental e as onomatopeias traduzidas.

Em traduções feitas por meio de scanlation, isso é ainda mais evidente. Segundo Aragão (2016), devido à preferência dxs fãs por traduções de mangás que se aproximem do texto fonte, elas tendem a não se desviar muito dele. Logo, são características comuns a não tradução de onomatopeias sem que haja a inserção de uma tradução do seu som como nas traduções profissionais, a manutenção dos nomes originais das personagens sem adaptações, assim como os honoríficos e outros elementos culturais japoneses. Além disso, também é comum que se encontre o uso de palavrões, gírias, de desvios de ortografia e sintaxe, sendo que esses últimos ocorrem, muitas vezes, para manter a sintaxe na língua meta mais próxima a do japonês. Sendo assim, toda tradução de mangás é marcada em relação ao seu caráter estrangeiro, e scanlations, em particular, são também marcadas quanto a desvios da norma padrão ${ }^{20}$. Resta, então, a associação entre as linguagens inclusivas e a "ideologia de gênero".

De qualquer forma, o uso de uma linguagem inclusiva poderia ser uma maneira interessante tanto de manter a não-binariedade de gênero dxs personagens quanto de visibilizá-la, além de a tradução ser uma forma de difundir a linguagem inclusiva e fomentar a sua aceitação. A seguir, analisaremos como essas decisões tradutórias se manifestam no nível microtextual.

A publicação da tradução amadora é feita por capítulo e com periodicidade irregular, com publicações de mais de um capítulo ao mesmo tempo podendo ocorrer ocasionalmente. Os capítulos são disponibilizados no blog a partir de publicações da própria tradutora responsável pela série. Compõem essas

\footnotetext{
${ }^{20}$ Apesar de essas escolhas tradutórias empregadas tanto por traduções profissionais quanto amadoras de mangás adotarem algumas das estratégias estrangeirizadoras propostas por Venuti e enfatizarem o caráter estrangeiro do texto fonte (pincipalmente no caso das traduções amadoras), não as considero como traduções estrangeirizadoras no sentido de Venuti. Enquanto para o autor, a estrangeirização tem um caráter político e de resistência, nos casos das traduções mencionadas aqui, as escolhas tradutórias se dão por motivos comerciais ou para satisfazer aos egos dxs leitorxs.
} 
publicações um título, geralmente informando de qual obra e capítulo se trata; a pessoa que fez a publicação, seguida de uma imagem, que pode ser a capa de um dos volumes do mangá ou uma arte de fã. Segue-se a isso uma brevíssima sinopse do capítulo ou capítulos em questão e links para baixar o capítulo ou lê-lo online.

As sinopses fornecidas pela tradutora já nos dão um vislumbre do que esperar em relação ao tratamento dado ao gênero dxs personagens do mangá, conforme podemos ver nas sinopses dos capítulos 2 e dos capítulos 39 ao 42 reproduzidas abaixo.

Fosfofilita é designada a criar uma enciclopédia de história natural para registrar tudo o que acontece na terra. Mas será que alguém pode ajuda-la para isto? Eis que todas indicam para ela uma companheira solitária e venenosa! (SAMORO, $18 / 11 / 2017)$

Nasce Cairngorm! O novo parceiro da Fos não está muito satisfeito com ela. Enquanto isso, as gems mais velhas aparecem para ajudar na patrulha contra... Lunários pequenos? (SAMORO, 18/01/2018)

A leitura das sinopses confirma o que a tradutora afirma em sua publicação sobre as mudanças que serão realizadas a partir do capítulo 80: foi usado o gênero feminino para referir-se à maioria dxs personagens, como indicam o uso do adjetivo "designada" e dos pronomes "la" em "ajudá-la" e "ela" associados ax personagem Fosfofilita, assim como o uso do pronome "todas" para referir-se axs personagens em geral, do artigo indefinido "uma", do substantivo "companheira" e dos adjetivos "solitária" e "venenosa" para referir-se a umx personagem não nomeadx. Também confirma o que a tradutora diz sobre o tratamento dado ao gênero $\mathrm{dx}$ personagem Cairngorm: utilizou-se apenas formas masculinas ao referir-se a elx, conforme evidenciado pelo artigo "o", o substantivo "parceiro" e os adjetivos "novo" e "satisfeito".

A seguir, veremos como essas escolhas tradutórias se manifestam na tradução. Abaixo, encontra-se um fragmento de cena retirado do segundo capítulo do mangá ${ }^{21}$.

\footnotetext{
${ }^{21}$ Todos os trechos do mangá reproduzidos na presente pesquisa seguem o sentido de leitura japonês. Logo, devem ser lidos da direita para a esquerda.
} 

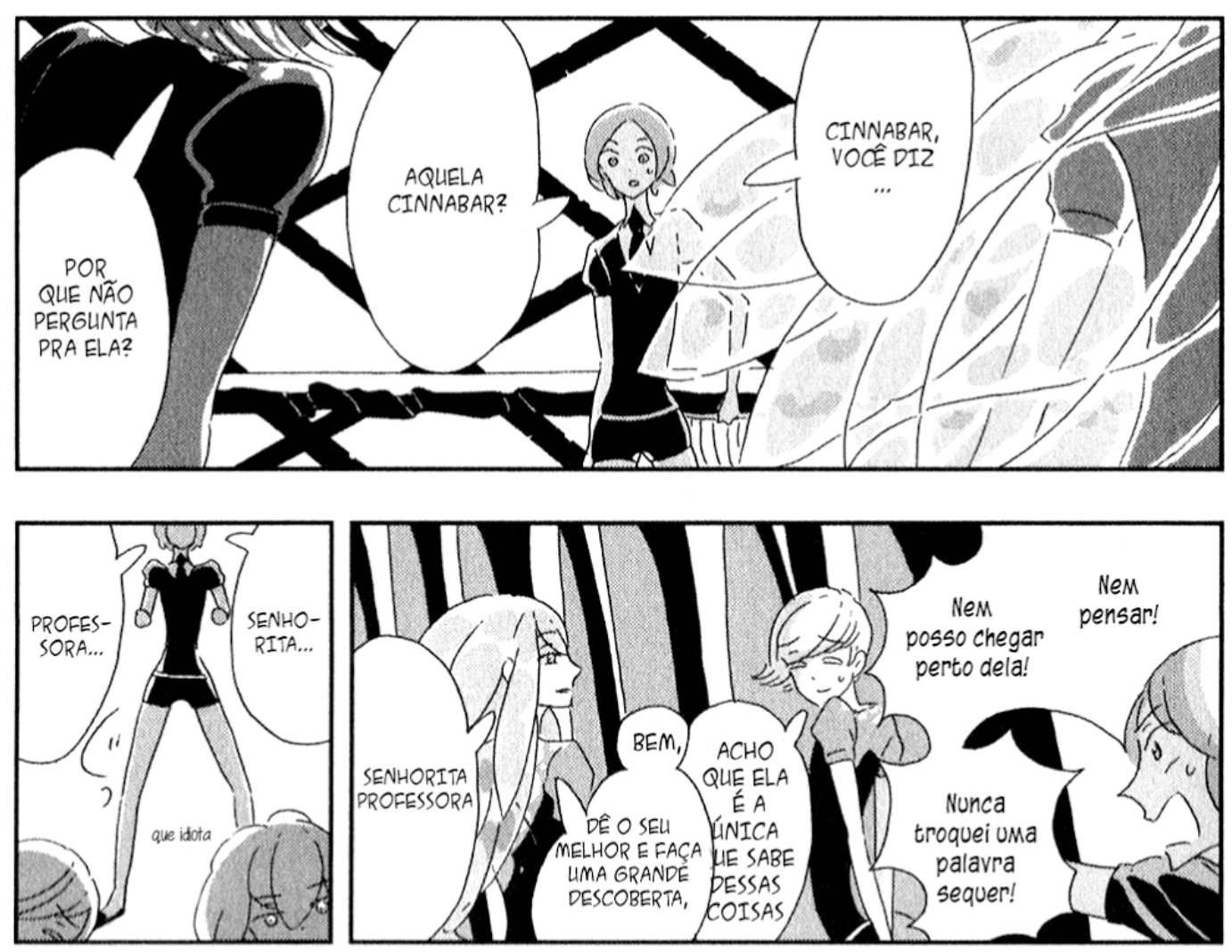

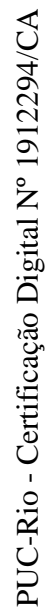
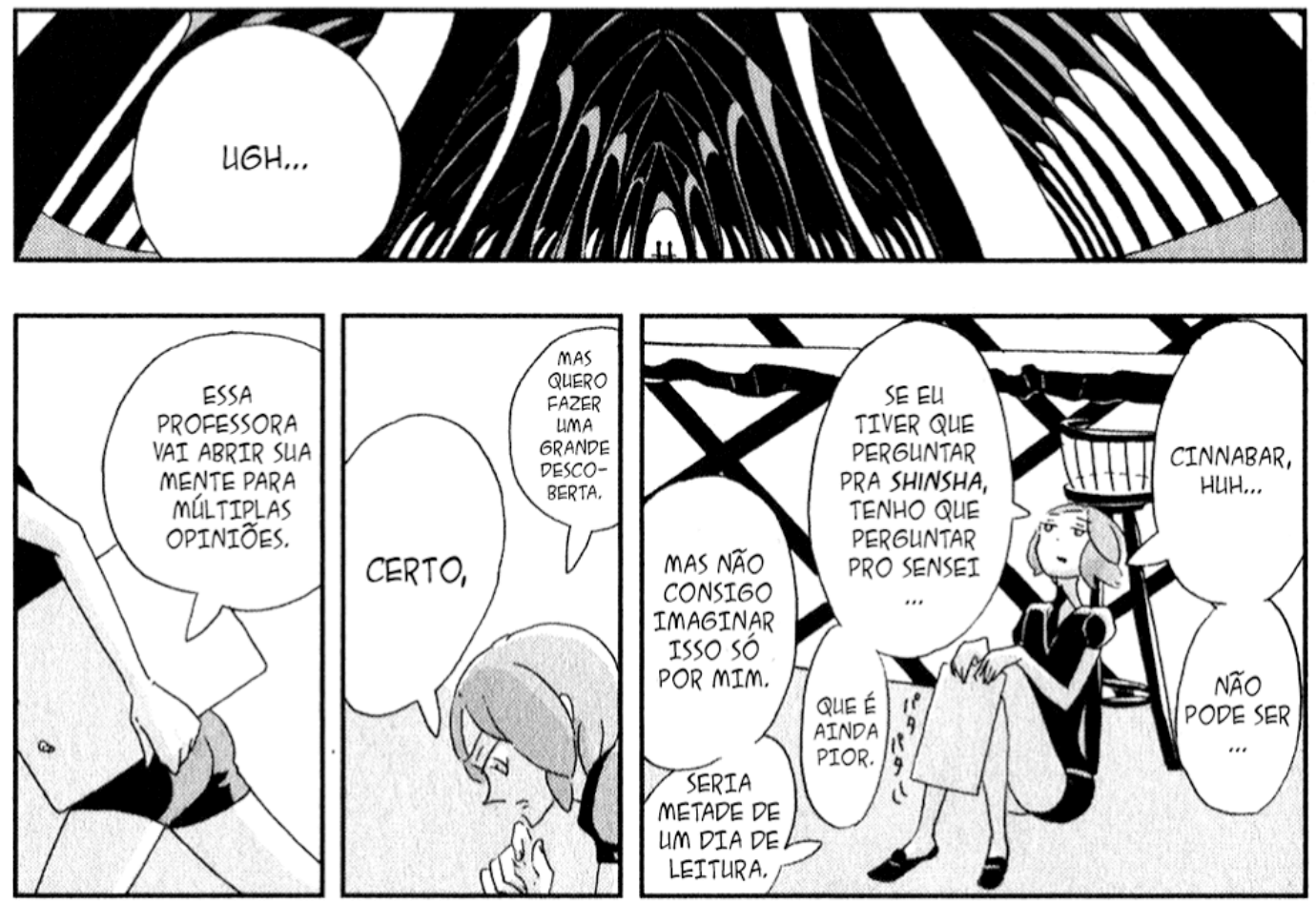

Figura 3: fragmento de cena do capítulo 2 (ICHIKAWA, 2017b, p.3)

O referente Cinnabar é introduzido no primeiro balão e, logo no segundo, um gênero lhe é atribuído com o uso do pronome demonstrativo "aquela" ("aquela Cinnabar?"). O processo de generificação prossegue com o uso da contração "dela" 
para referir-se ax personagem ("Nem posso chegar perto dela!") e, posteriormente, pelo uso do pronome feminino de terceira pessoa "ela", do artigo definido feminino "a" e do adjetivo também no feminino "única" ("Acho que ela é a única que sabe dessas coisas"). Fosfofilita é também generificadx por Morganita através do uso do pronome de tratamento "senhorita" e pelo substantivo feminino "professora", que é reproduzido por Fosfofilita no quadro seguinte. Mais adiante, é utilizada a contração "pra" antes de "Shinsha" ("se eu tiver que perguntar pra Shinsha [...]") e, por fim, Fosfofilita refere-se a si mesmx através do pronome demonstrativo "essa" seguido do substantivo feminino "professora" ("Essa professora vai abrir a sua mente para múltiplas opiniões").

$\mathrm{Na}$ tradução amadora para o português perde-se por completo a possibilidade de ler-se xs personagens como não-binárixs devido à opção de designar-lhes o gênero feminino. No entanto, a estrutura da língua desempenhou um papel importante nesse processo. Diferentemente de uma língua como o inglês, na qual o gênero se limita a alguns pronomes e substantivos, na língua portuguesa, todo substantivo possui um gênero, que pode ser apenas masculino ou feminino. Assim, enquanto na primeira uma palavra como "stone" é neutra, a sua correspondente em português "pedra" é feminina. Além disso, a língua portuguesa, como se sabe, possui gênero gramatical, o que significa que o gênero não se limita apenas aos substantivos, havendo a necessidade de concordância de gênero entre esses e as palavras que estiverem associadas a eles na oração. No trecho analisado, pode-se notar essa característica do português na oração "Acho que ela é a única que sabe dessas coisas": devido ao fato de ter sido utilizado o pronome feminino "ela", esse gênero precisou ser estendido ao adjetivo "única" e ao artigo definido "a" que o acompanha. Tudo isso implica que manter a não-binariedade de gênero na língua portuguesa é uma tarefa muito mais árdua que em uma língua como o inglês, podendo inclusive ser considerada impossível a não ser que sejam tomadas algumas liberdades em relação à norma padrão.

A análise do trecho demonstra que a estratégia tradutória explicitada tanto na nota da tradutora quanto no texto publicado no blog do grupo de tradução foi, de fato, seguida. Xs personagens tiveram a sua não-binariedade de gênero apagada, sendo-lhes designado o gênero feminino na maioria dos casos e o masculino para xs personagens Antarticita e Cairngorm, conforme pode ser observado no 
exemplo abaixo. Dessa forma, xs personagens não podem mais ser lidxs como não-binárixs.

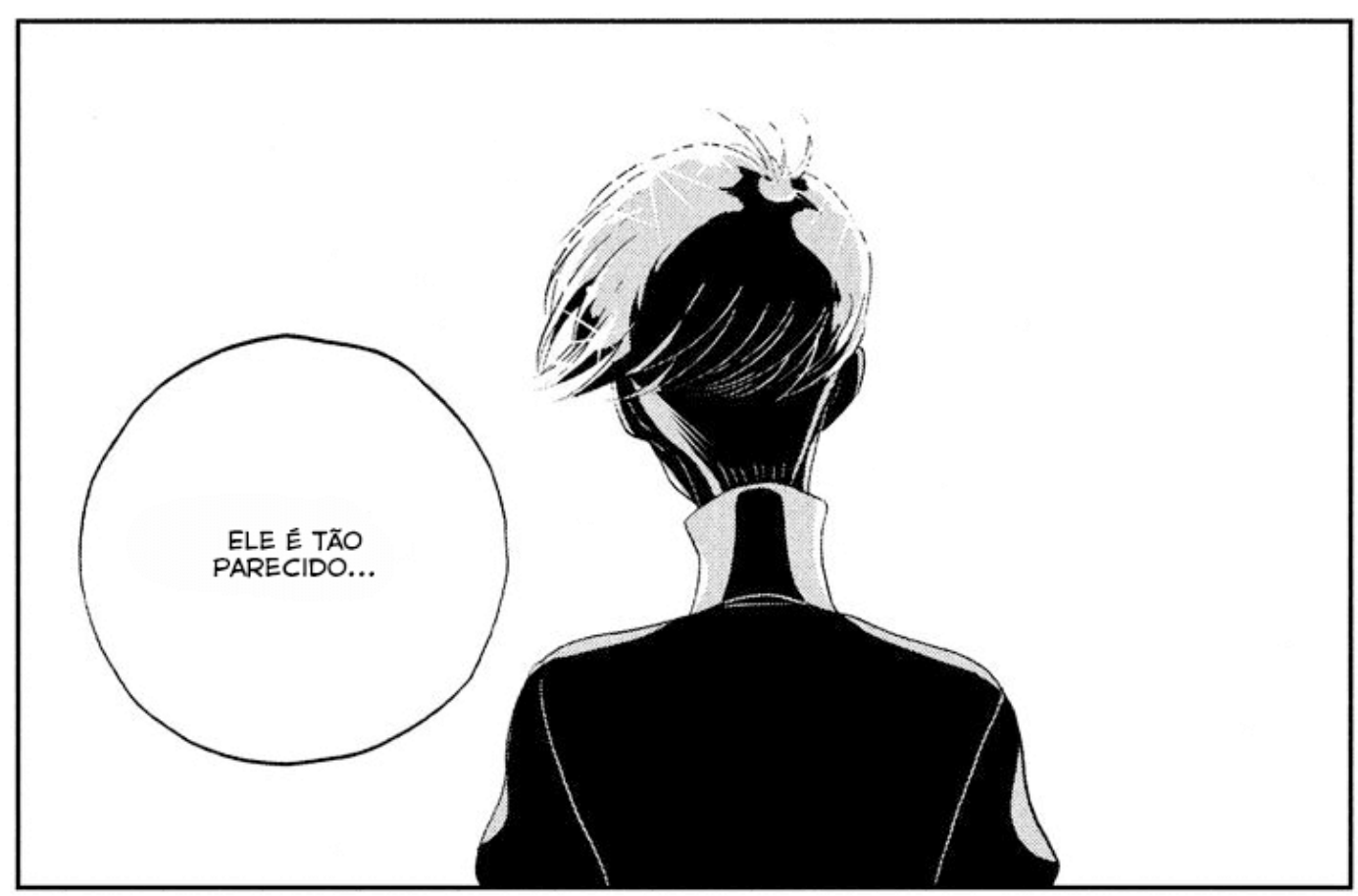

Figura 4: uso do masculino para se referir ax personagem Cairngorm (ICHIKAWA, 2018, p.21)

As informações contidas na nota e na publicação no blog também se confirmam em relação às mudanças na tradução do mangá a partir do capítulo 80 . No trecho abaixo, vemos que xs personagens passaram a ser tratadas no masculino, evidenciado pela contração "do" em "...você tem a mesma idade do Dia, né?" e pelo uso do pronome "ele" para recuperar o referente logo em seguida. A fala de Cinnabar na segunda vinheta demonstra também um certo esforço por parte da tradutora em manter a referência neutra através da elipse do pronome que serviria para recuperar o referente "Dia" ("Acho que [Ø] está melhor do que deveria"), apoiando-se, em vez disso, na desinência pessoal dos verbos "está" e "deveria" como forma de recuperá-lo. Contudo, ao longo dos capítulos, são raras instâncias em que recursos para manter a referência neutra são utilizados, predominando o uso do masculino. 

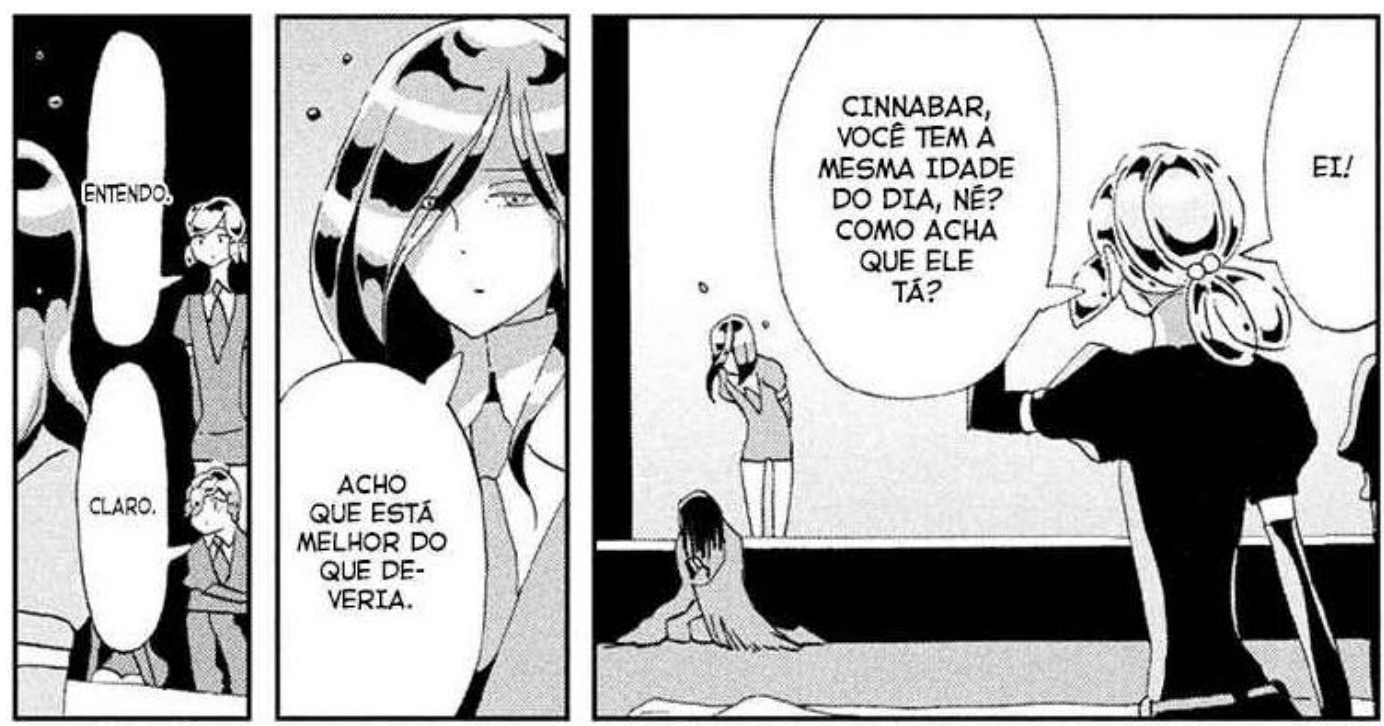

Figura 5: uso do masculino genérico a partir do capítulo 80 (ICHIKAWA, 2020c, p.7)

Dessa forma, as alterações feitas na tradução a partir do capítulo 80 não contribuem para manter a não-binariedade de gênero dxs personagens, servindo apenas para mudar a sua designação de gênero do feminino para o masculino e para reforçar o masculino genérico como a norma. A nota e a publicação no blog, por outro lado, oferecem uma certa visibilidade às identidades não-binárias $d x s$ personagens ao explicitarem que elxs não têm um gênero, mas visto que tratam-se de instâncias isoladas e ocorrem muito tempo depois do início da publicação da tradução amadora, o seu efeito dificilmente será relevante.

Um outro aspecto acerca da tradução amadora para o português que vale a pena ressaltar é o potencial desestabilizador que o uso do masculino genérico pode ter na tradução do mangá Houseki no kuni especificamente. Dado que, como temos visto no decorrer da presente dissertação, xs personagens tendem a ser percebidxs como femininxs pelo público leitor, ver personagens que "parecem meninas e agem como meninas" referindo-se a si mesmxs e umxs axs outras no masculino pode vir a causar um certo estranhamento nxs leitorxs. Seu uso poderia desestabilizar a noção de que o fato de uma pessoa ou personagem apresentar características físicas ou traços de personalidade ideologicamente associados a um determinado gênero não significa que irá, necessariamente alinhar-se ao genero em questão.

Contudo, devido ao fato de xs personagens do mangá não terem um gênero especificado e dada a posição marginalizada que pessoas não-binárias ocupam na 
sociedade, considero de maior importância que o aspecto não-binário das identidades dxs gemas seja mantido. Ademais, o possível efeito desestabilizador do uso do masculino genérico também poderia ser alcançado de forma ainda mais contundente por meio do uso de algum tipo de linguagem inclusiva.

\subsection{Traduções amadoras para o inglês e o espanhol}

Os dados referentes às traduções amadoras para o inglês e o espanhol analisadas na presente pesquisa foram coletados em sites especializados na publicação dessas traduções. É comum que traduções feitas por um mesmo grupo apareçam em diferentes sites do tipo, devidamente creditadas. Neles são destinadas páginas aos diferentes títulos, que contam com sinopses, informações sobre a obra (título, autor, gênero, ano de publicação etc.), uma lista de todos os capítulos publicados, com os links para a leitura de cada um e as suas respectivas datas de publicação no site. Segue-se a isso uma seção de comentários. Diferentemente do site da tradução amadora para o português, não é disponibilizado um espaço para que xs tradutorxs falem sobre suas traduções, de forma que as únicas informações disponíveis acerca das estratégias tradutórias utilizadas foram aquelas presentes nas notas que acompanhavam as traduções. $\mathrm{Na}$ próxima seção, será analisada a tradução amadora para o inglês que se encontra no site agregador https://manganelo.com/.

\subsubsection{Tradução amadora para o inglês}

Ao clicar no link do primeiro capítulo da tradução amadora para o inglês, somos direcionados a uma nova página que se inicia com uma nota de tradutor $\mathrm{x}^{22}$ com informações a respeito do gênero dxs personagens na qual se lê:

001 No japonês, é fácil falar sem se referir ao gênero de alguém.

002 Entretanto, nos casos em que se referem a uma ${ }^{23}$ personagem 003 utilizando pronomes generificados neste mangá, as personagens 004 parecem usar exclusivamente pronomes masculinos (ele, irmão mais 005 velho, etc.). A maioria delas também utiliza formas masculinas de

\footnotetext{
${ }^{22}$ Não é possível saber o nome dx tradutorx pois não está presente na nota, e a tradução é assinada como "a certain's anonynous translation".

${ }^{23}$ Optei por não utilizar o " $\mathrm{x}$ " aqui pois poderia fazer parecer que $\mathrm{x}$ autorx da nota teve a intenção de manter a não-binariedade de gênero dxs personagens quando não foi o caso.
} 
006 dizer "eu" (boku, ore), enquanto que os seus padrões de fala variam 007 bastante entre o masculino e o feminino.

008 É possível que as personagens, na verdade, não tenham um conceito de 009 gênero em sua sociedade e estejam apenas utilizando o masculino 010 genérico como no inglês arcaico ou algo assim.

Apesar de isto não ser dito de forma explicita, a nota de tradutorx parece oferecer uma justificativa para as escolhas tradutórias. Como veremos mais adiante, a tradução amadora para o inglês optou por generificar xs personagens no masculino. Em sua nota, x tradutorx reconhece a possibilidade de xs personagens não terem um gênero, mas, ao mesmo tempo, o seu texto é estruturado de forma a argumentar em favor do masculino genérico. Nesse sentido, o fato de iniciar com uma afirmação categórica acerca da possibilidade de se falar de uma pessoa sem se referir ao seu gênero na língua japonesa, seguida de uma explicação sobre a forma como o gênero é utilizado no mangá, é significativo, pois parece sugerir que o uso do masculino foi uma escolha deliberada da autora. Além disso, embora seja reconhecido que os padrões de fala dxs personagens variem entre o masculino e o feminino - o que sugere uma certa ambiguidade de gênero ${ }^{24}$ - e a possibilidade de xs personagens não terem um conceito de gênero, o último parágrafo da nota procura estabelecer um paralelo entre os usos das formas masculinas no mangá e o masculino genérico do inglês, dando a entender que utilizá-lo seria a forma mais "fiel” de traduzir.

\footnotetext{
${ }^{24}$ Há um debate em torno da existência de uma "linguagem das mulheres" na língua japonesa. Segundo Camp (2009), essa linguagem manifesta-se nas escolhas lexicais, por usos específicos de honoríficos e partículas de final de frase, além de diferenças de entonação, tom de voz e fonologia segmental. Essa linguagem geralmente é considerada mais educada, gentil, não assertiva e empática do que aquela comumente associada aos homens, refletindo a posição inferior que as mulheres tendem a ocupar na sociedade japonesa (CAMP, 2009). Contudo, a autora também aponta que tem havido uma mudança em direção a usos de linguagem mais neutros por gerações mais jovens de mulheres e que outros fatores também exercem influência sobre esses usos de linguagem, como idade, status, sexualidade e identidade de gênero. Tais influências podem ser observadas nos usos dos pronomes masculinos mencionados na nota de tradutorx acima por mulheres jovens como forma de resistência (MIYAZAKI, 2004), ou o uso mais frequente de elementos comumente associados à fala dos homens por mulheres japonesas que se identificam como lésbicas (CAMP, 2009). O emprego tanto de pronomes masculinos como padrões de fala considerados femininos pelxs personagens de Houseki no kuni em seus discursos parece sugerir que Ichikawa procura criar, por meio da linguagem, a mesma ambiguidade de gênero presente nas imagens (ver seção 1.5) ao incorporar características associadas à fala de ambos os gêneros.
} 
In Japanese, it's easy to speak without referring to a someone's gender.

However, in the cases that a character is referred to using gendered pronouns in this manga, the characters appear to exclusively use male pronouns (he/彼、 elder brother/お兄様, etc) . Most of them also use masculine ways of saying "I" (boku, ore), while their personal speech patterns vary greatly between masculine and feminine.

It's possible that the characters don't actually have a concept of gender in their society and are merely defaulting on masculine pronouns like archaic English or something.

Figura 6: nota dx tradutorx da tradução amadora para o inglês (ICHIKAWA, 2020a, p.1)

Veremos, no trecho abaixo, as maneiras como as estratégia tradutórias presentes na nota aparecem no texto. 

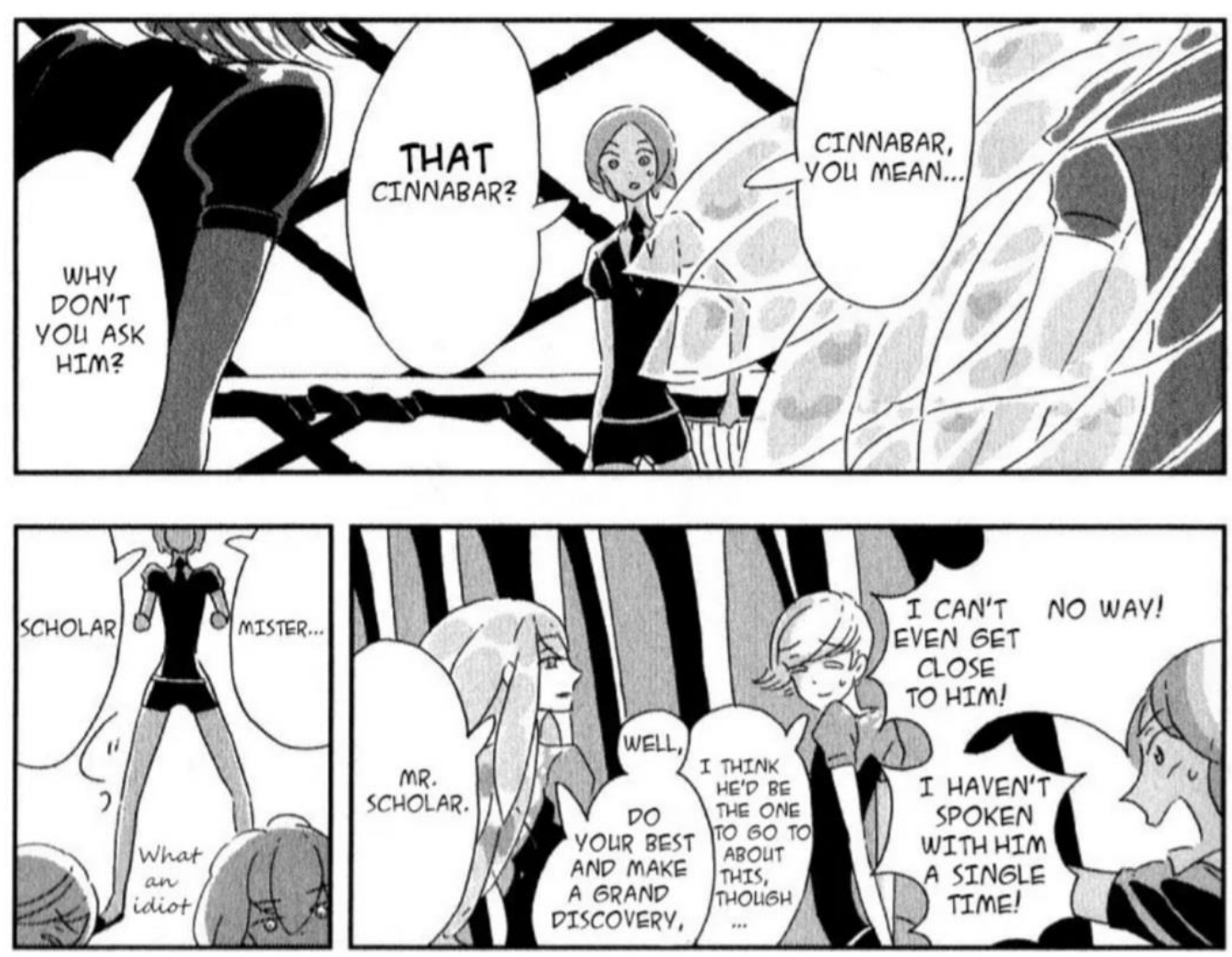

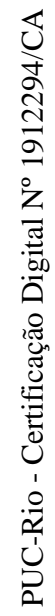
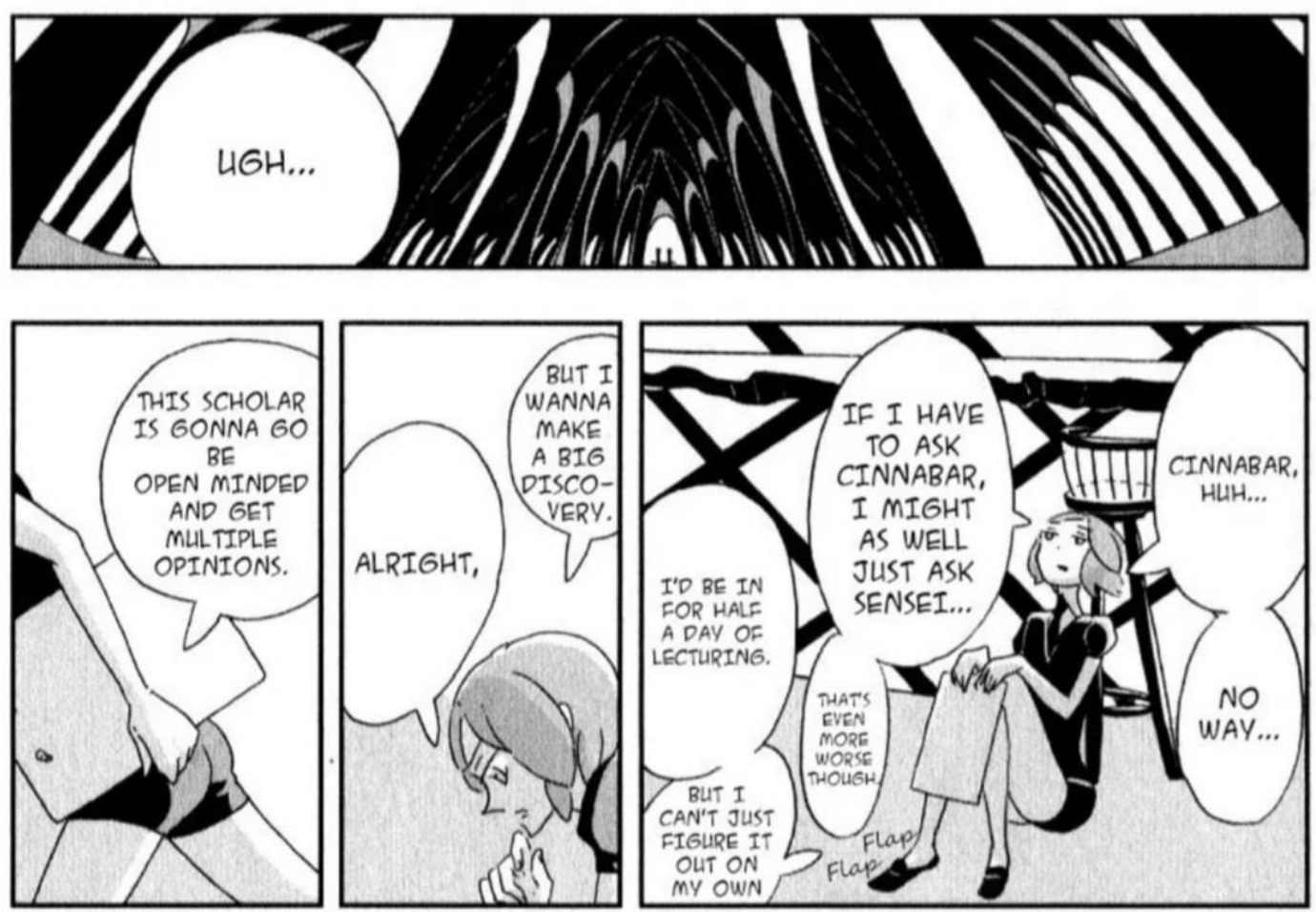

Figura 7: fragmento de cena do capítulo 2 (ICHIKAWA, 2020b, p.3)

$\mathrm{Na}$ versão norte-americana feita por scanlation a possibilidade de ler-se xs personagens como não-binárixs é eliminada. O referente "Cinnabar" é introduzido no primeiro balão e, logo adiante, retomado por Goshenita através do uso do 
pronome masculino de terceira pessoa "him" (“Why don't you ask him?”). No decorrer da cena, os pronomes "he" e "him" são as formas utilizadas para referirse ax personagem Cinnabar (“I can't even get close to him!", "I haven't spoken with him a single time!", "I think he'd be the one to go to about this, though..."). Além disso, Morganita utiliza o pronome de tratamento "mister" ("mr. scholar") ao referir-se ax personagem Fosfofilita, que o reproduz posteriormente. Nos quadros seguintes, Cinnabar volta a ser referenciadx, porém, isso é feito utilizando o seu próprio nome, evitando-se assim a recorrência do uso de formas generificadas.

Como se pode notar, a versão norte-americana em scanlation optou por generificar xs personagens no masculino a partir da escolha dos pronomes utilizados, sem demonstrar qualquer preocupação em manter a sua nãobinariedade de gênero. Talvez isso seja melhor exemplificado no trecho abaixo: ao falar sobre x personagem Cinnabar, Fosfofilita utiliza três vezes o pronome masculino "him", duas vezes o pronome "he" e o pronome "his" uma vez, tudo isso em apenas três frases. Em momento algum é empregada qualquer forma de coesão textual que mantenha a referência neutra, optando, em vez disso, pelo constante reforço do masculino.
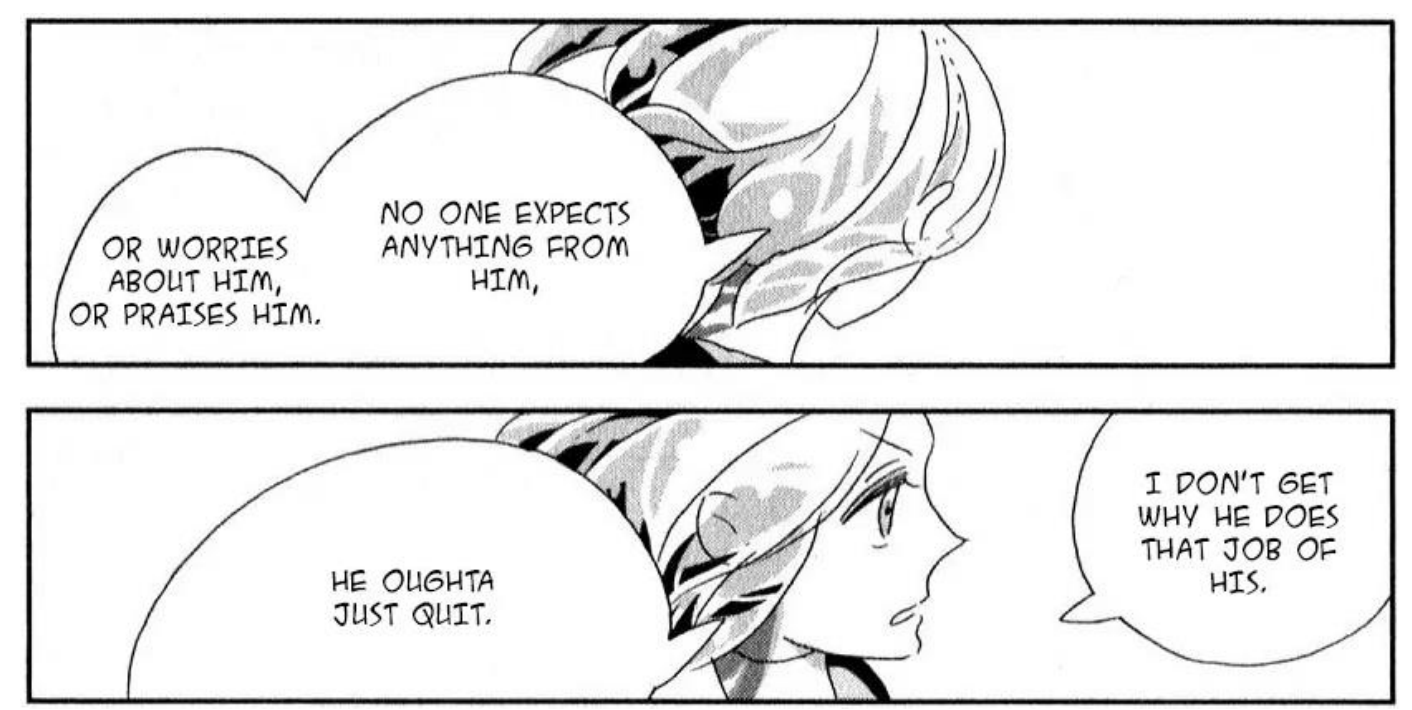

Figura 8: exemplo de reforço do masculino (ICHIKAWA, 2020b, p.8)

Como veremos na análise da tradução profissional mais adiante, a língua inglesa possibilita outras formas de recuperação do referente em terceira pessoa, não estando limitada ao uso de pronomes. Contudo, optando-se pelo seu uso, o 
inglês oferece uma opção que possibilita que seja mantida a não-binariedade de gênero: o uso dos pronomes em terceira pessoa do plural "they/them/their" para referir-se a uma pessoa no singular. Apesar de essa forma do uso desses pronomes ainda ser um pouco controversa, sendo rejeitada por alguns por não ser "gramaticalmente correta", seu uso tem sido mais aceito recentemente (HORD, 2016). Curiosamente, essa estratégia é utilizada na tradução do capítulo 30 do mangá. Contudo, esse é um caso aparte, dado que não ocorre novamente em nenhum outro dos 95 capítulos publicados até o momento.

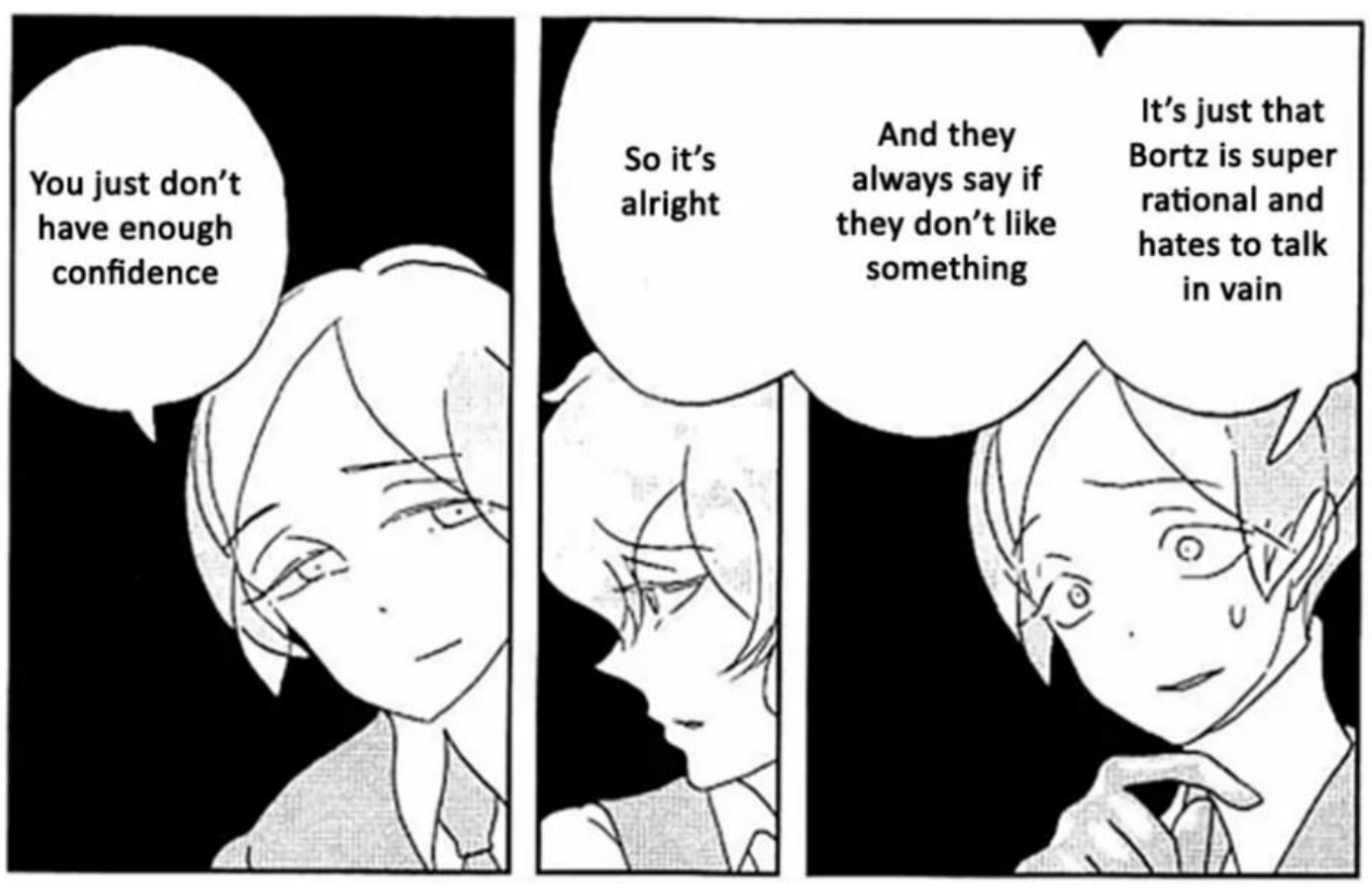

Figura 9: exemplo do uso do pronome "they" no singular (ICHIKAWA, 2019, p.12)

Vale ressaltar que traduções em scanlation são feitas por fãs que não são tradutorxs profissionais e que, em geral, traduzem as obras diretamente do japonês porque as apreciam e desejam compartilhá-las com outrxs leitorxs. Essxs tradutorxs são geralmente estudantes universitárixs que têm o japonês como segunda ou terceira língua (ARAGÃO, 2016). Assim, "por se tratar de um trabalho realizado por fãs, não há critérios tradutológicos pré-definidos nem técnicos profissionais, ao mesmo tempo em que também não há correções, imposições ou censura impostas por uma editora [...]" (ARAGÃO, 2016, p.80), o que, por um lado permite uma certa liberdade por parte dxs tradutorxs para escolher como lidar com essa característica da obra, mas, por outro, pode levar a 
uma falta de preocupação com a manutenção da não-binariedade de gênero, ou a uma falta de conhecimento acerca das possibilidades que a língua inglesa oferece para tal. Somados à inserção dos indivíduos em uma sociedade cisheteronormativa, como mencionado na seção 2.3.1, esses fatores podem contribuir para o apagamento do conteúdo LGBTQAI+ da obra.

\subsubsection{Tradução amadora para o espanhol}

De forma semelhante à tradução amadora para o inglês, ao clicar no link do primeiro capítulo, somos direcionados a uma nova página que se inicia, também, com uma nota de tradutorx com informações a respeito do gênero dxs personagens na qual se lê:

001 Em japonês é muito fácil falar sem mencionar o gênero do sujeito.

002 Neste mangá, os personagens usam pronomes neutros. É compreensível

003 que, sendo outra espécie não humana, eles não tenham conceito algum de gênero.

004

005 Nas poucas vezes em que usam pronomes definidos, são 006 majoritariamente masculinos, embora a situação varie muito. Para 007 manter a coesão, usarei apenas pronomes masculinos. São livres para considerar os personagens masculinos ou femininos ou o que lhes der na telha.

A nota em questão inicia-se de maneira idêntica à nota que introduz o primeiro capítulo da tradução amadora para o inglês: $x$ autorx (que, assim como na nota da tradução amadora norte-americana, não pode ser identificadx) a inicia com a mesma afirmação categórica sobre a possibilidade que a língua japonesa oferece de referir-se a alguém sem especificar um gênero. Após essa frase inicial, no entanto, os textos passam a divergir. Por exemplo: apesar de apontar, como na nota em inglês, que nas vezes em que xs personagens utilizam pronomes generificados, esses são majoritariamente masculinos, aqui também é assinalado que esses usos são menos comuns, e pronomes neutros são utilizados mais frequentemente. Além disso, o fato de xs personagens não terem um gênero especificado não é apresentado apenas como uma possibilidade, mas sim como algo que pode ser deduzido com base na narrativa e no seu jeito de falar. Por fim, 
enquanto na nota da tradução amadora norte-americana, a estratégia geral da tradução em relação ao gênero dxs personagens (o uso do masculino genérico) pode ser apenas deduzida a partir do seu conteúdo e da organização do texto, na nota da tradução para o espanhol, essa estratégia é explicitada na penúltima linha.

Contudo, é interessante notar que, embora haja algumas diferenças no conteúdo das duas notas, as semelhanças, tanto no texto quanto no formato, indicam que a nota em espanhol pode ser uma tradução da nota em inglês (embora seja uma tradução livre, como indicado no canto superior). De fato, é o que parece sugerir a nota que passa a anteceder os capítulos do segundo ao $13^{\circ}$ e do $18^{\circ}$ ao $44^{025}$, sendo essas escritas pelo grupo Venezuela no fansub (VNF), responsável pela tradução para o espanhol que será analisada nessa pesquisa.
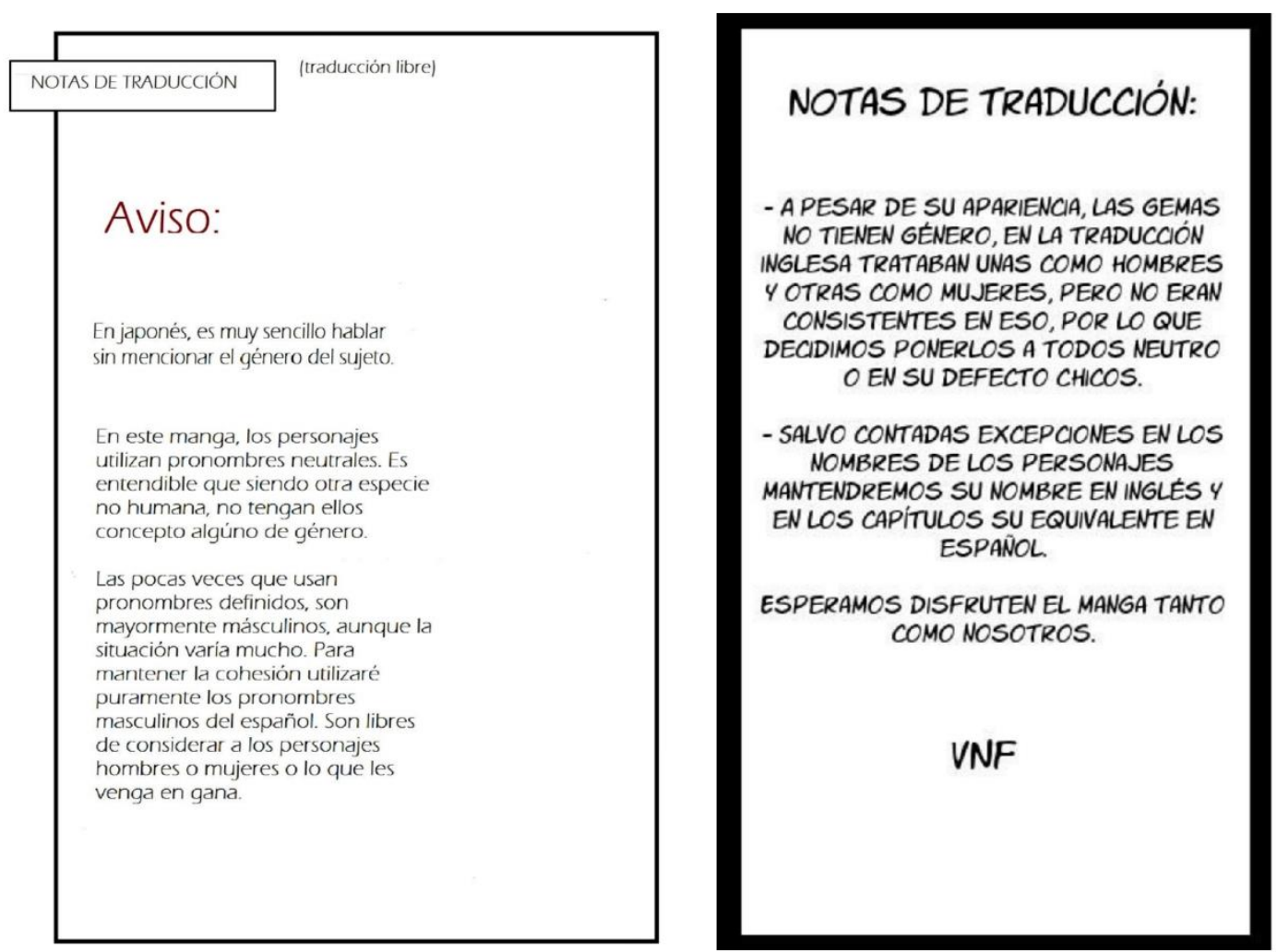

Figura 10: notas da tradução amadora para o espanhol

Conforme pode ser lido abaixo na tradução abaixo, a segunda nota também contém informações a respeito do gênero dxs personagens e a estratégia tradutória que será adotada para lidar com isso:

\footnotetext{
${ }^{25}$ Não ficou claro se esse hiato no aparecimento das notas se deu por uma mudança no grupo responsável pelas traduções ou se foi por alguma outra razão, pois xs tradutorxs não foram creditados entre os capítulos 14 e 17.
} 
001 Apesar de sua aparência, as gemas não têm gênero, na tradução 002 inglesa, tratavam algumas como homens e outras como mulheres, 003 porém, não eram consistentes nisso, por isso, decidimos colocá-los 004 todos neutros ou no masculino padrão.

005 Salvo algumas exceções, nos nomes das personagens, manteremos seu 006 nome em inglês e, nos capítulos, seu equivalente em espanhol.

007 Esperamos que desfrutem do mangá tanto quanto nós.

A nota reforça que a estratégia adotada em relação ao gênero dxs personagens é de utilizar o masculino genérico, porém, aqui a justificativa fornecida é em relação à forma como a tradução para o inglês trata o gênero dxs personagens. Isso, somado ao fato de as informações sobre a possibilidade de se referir a alguém sem mencionar o seu gênero na língua japonesa não serem trazidas como nas outras notas, sugere se tratar de uma tradução indireta. No lugar das informações sobre a língua japonesa, é trazida a informação acerca do fato de xs personagens não terem um gênero. Diferentemente das demais, aqui essa informação é apresentada de forma categórica, não deixando espaço para dúvidas ou interpretações. Chama a atenção o fato de esta informação iniciar-se com uma ressalva acerca da aparência dxs personagens, pois alude ao fato de que um gênero pode ser-lhes designado no ato de leitura com base em seus desenhos.

A leitura das notas sugere uma abordagem paradoxal por parte da tradução amadora para o espanhol: as notas enfatizam o fato de xs personagens não terem um gênero (em especial a segunda nota analisada), fazendo uso desse recurso como uma maneira de visibilizar essa característica, conforme sugerido por Lewis (2010). Isso é reforçado pelo fato de a nota ser repetida antes de vários capítulos, fazendo com que xs leitorxs sejam expostxs a essa informação e lembradxs desse fato antes da leitura. Ao mesmo tempo, porém, a nota deixa claro que a estratégia adotada no nível microtextual será a de utilizar o masculino genérico, de maneira que um gênero será atribuído axs personagens. A justificativa da coesão dada na primeira das notas aponta também para uma possível influência das limitações imposta pela estrutura das línguas neolatinas a uma tradução queer do mangá.

No trecho abaixo, veremos como as estratégias explicitadas nas notas materializaram-se na tradução. Considerando que a tradução amadora para o 
espanhol parece ter sido uma tradução indireta feita a partir da tradução amadora norte-americana, levarei essa última em consideração em minha análise.
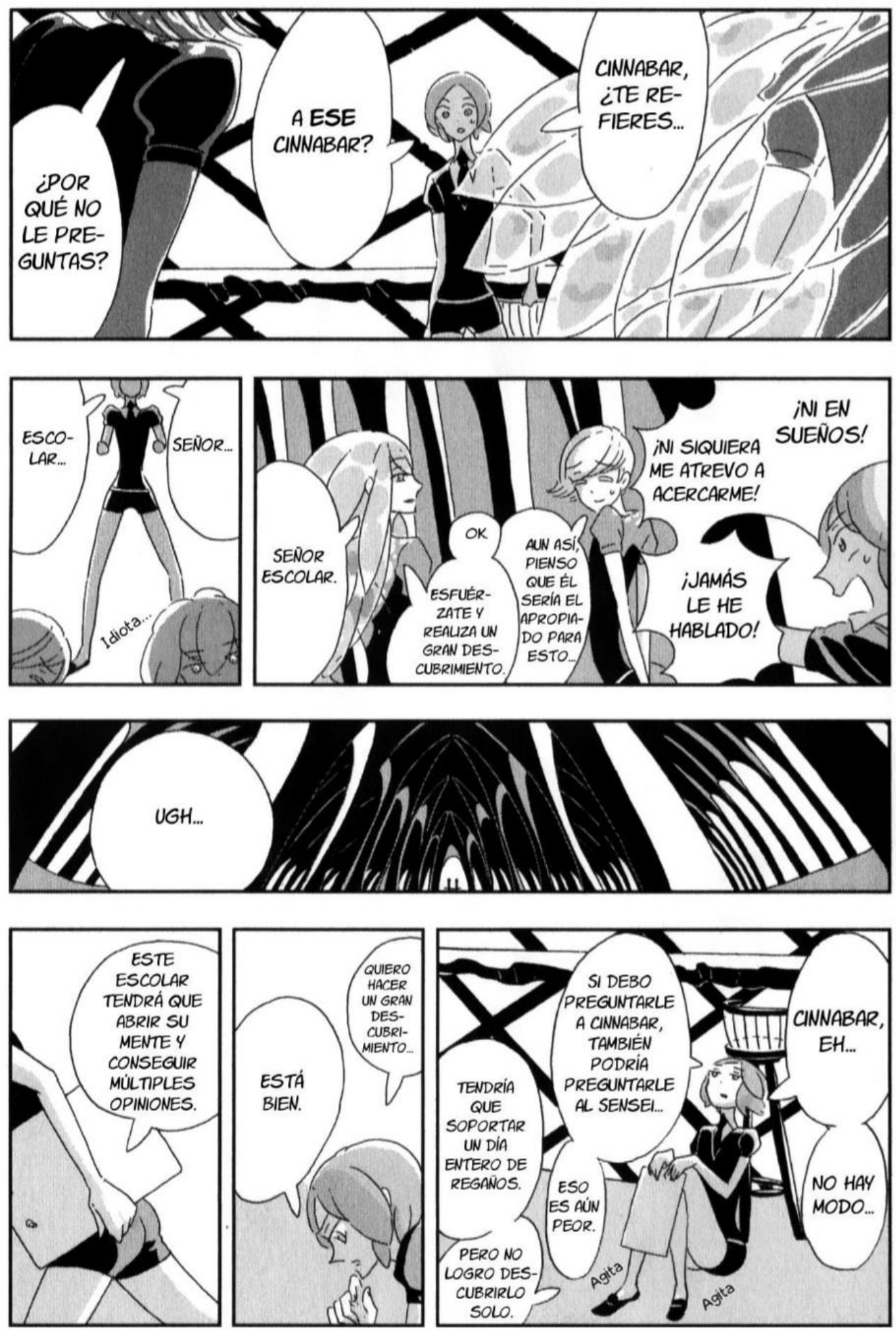

Figura 11: fragmento de cena do capítulo 2 (ICHIKAWA, 2016c, p.4) 
O referente Cinnabar é introduzido no primeiro balão e, ao ser retomado no segundo, utiliza-se o pronome masculino "ese" (“A ese Cinnabar"). A seguir, Goshenita faz uso do pronome masculino "él" para retomar o referente Cinnabar, e posteriormente Morganita refere-se ax Fosfofilita pelo pronome de tratamento masculino "señor". Por fim, Fosfofilita emprega o pronome masculino "este" para referir-se a si mesmx no último quadro da página. Como se pode notar, a tradução amadora para o espanhol atribui o gênero masculino axs personagens, conforme explicitado nas notas de tradução analisadas.

O grande número de referências neutras indica que pode ter havido um esforço por parte da tradução amadora para minimizar a generificação dxs personagens. A primeira instância dessa neutralização ocorre no terceiro balão da primeira vinheta, no qual é empregado o pronome neutro "le" onde, na tradução norte-americana, utilizou-se o masculino “him” (“¿Por qué no le preguntas?”), sendo o mesmo recurso empregado no terceiro balão da vinheta seguinte (“¡Jamás le he hablado!"'). $\mathrm{Na}$ segunda vinheta, o pronome masculino é novamente substituído por uma referência neutra, porém dessa vez por meio do uso de uma elipse (“;Ni siquiera me atrevo a acercar-me $[\varnothing]$ !”).

O uso desse recurso para manter a referência neutra "sempre que possível" pode ser melhor visualizado no trecho abaixo. Nele o referente Cinnabar é introduzido por Benito no primeiro balão e retomado mediante o uso de uma elipse logo em seguida (" ¿Necesitas algo de Cinnabar? [ $\emptyset]$ probablemente no esté dentro."). A elipse é novamente empregada para retomar o referente no quinto balão da mesma vinheta, sendo a desinência pessoal do verbo a responsável por retomar o referente (“más bién, [Ø] nunca está adentro.”). O mesmo ocorre nas falas da terceira vinheta ("En ocasiones [ $\varnothing]$ no puede controlar su veneno, ¿Sabes?”; "Quizás [Ø] se sentió mal al respecto o algo de eso, pues [Ø] no há vuelto en um buen tiempo."). Na quinta vinheta, o gênero masculino volta a ser atribuído ax Cinnabar por meio do uso da expressão "de ese tipo" ("El veneno de ese tipo es como su respiración o algo."), porém, a elipse é novamente empregada em seguida para manter o referente neutro ("Sé que [Ø] intenta no ser una molestia."; "no me puedo relajar cuando [Ø] está cerca."). Assim, a tradução amadora para o espanhol é capaz de alcançar o seu objetivo de manter a nãobinariedade do referente "sempre que possível" omitindo-o por meio de elipses e apoiando-se nas desinências pessoais dos verbos para recuperá-lo. 

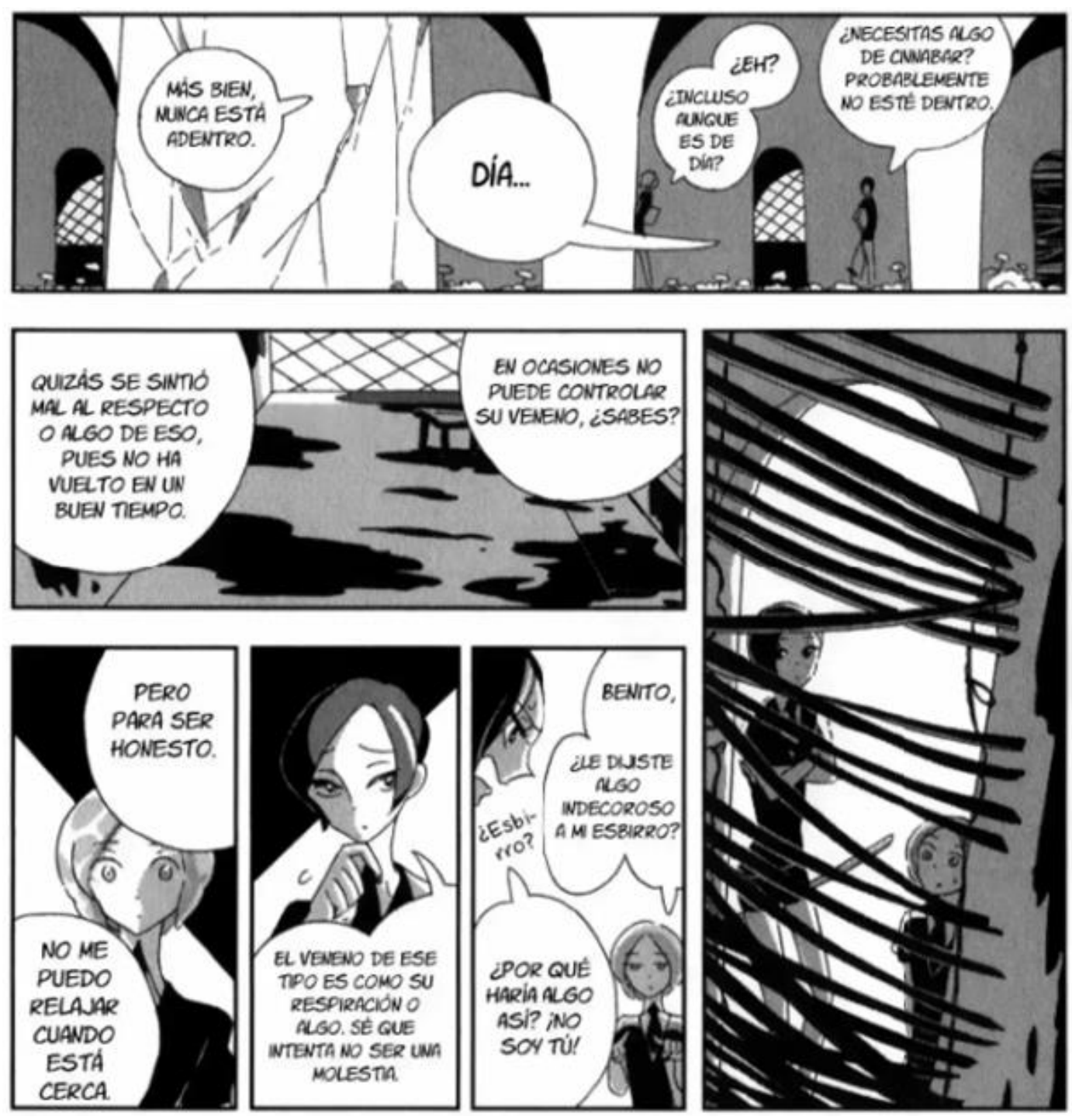

Figura 12: exemplo do uso de elipses para manter a referência neutra (ICHIKAWA, 2016c, p.8)

Todavia, manter a referência sempre neutra em uma língua como o espanhol é uma tarefa bastante difícil de sustentar. O espanhol, assim como o português, é uma língua gramaticalmente generificada, e, assim como o português, todos os substantivos têm um gênero que pode ser apenas masculino ou feminino, necessitando haver concordância de gênero entre os elementos da oração. Essa caracterísica do espanhol impõe um grande obstáculo à manutenção da nãobinariedade de gênero dxs personagens na tradução.

Contudo, o espanhol apresenta também algumas diferenças em relação à língua portuguesa que podem auxiliar na tarefa de não generificar xs personagens na tradução, em especial aquelas que concernem ao uso dos artigos nessas duas línguas. Eckert (2017) aponta algumas dessas diferenças, dentre as quais é 
relevante para a presente pesquisa a inadequação do uso de artigos definidos antes de nomes próprios: enquanto no português os artigos geralmente acompanham esses substantivos, no espanhol, tende-se a evitá-los. Assim, um dos elementos responsáveis por generificar xs personagens em língua portuguesa (e aquele que é mais difícil de se contornar) não está presente na língua espanhola. Com isso, o desejo de manter as referências neutras quando possível expresso nas notas de tradução constitui uma tarefa bem menos difícil para a tradução para o espanhol do que para o português.

\subsection{Tradução profissional para o francês}

Diferentemente das traduções amadoras, a tradução profissional francesa é publicada em volumes contendo em média 7 capítulos e em torno de 200 páginas cada. A capa apresenta o mesmo modelo da edição japonesa, com algumxs dxs personagens estampando a arte da capa, o título da tradução ao centro, seguido pelo número do volume. Logo abaixo, encontra-se o nome da autora em letras menores, e, no canto inferior esquerdo, o nome da editora. Essas mesmas informações verbais são repetidas na lombada. Para a classificação indicativa, a tradução francesa não informa uma faixa etária específica, utilizando, em vez disso, o sistema japonês de indicação do público-alvo, segundo o qual, o mangá é classificado como seinen, isto é, voltado para um público maduro. A opção por informar axs potenciais leitorxs sobre a classificação indicativa da obra dessa maneira pressupõe uma certa familiaridade com esse sistema por parte destxs, além de constituir-se como uma opção estrangeirizadora por parte da tradução. Por fim, a contracapa do mangá apresenta o desenho de umx dxs personagens, acompanhada de uma sinopse do volume que estranhamente aparece na forma de um poema, diferentemente das demais sinopses que acompanham as traduções. $\mathrm{O}$ nome da tradutora, Anne-Sophie Thévenon, é creditado na folha do expediente.

A edição francesa não apresenta paratextos na forma de prefácios, posfácios ou notas de tradução. Além disso, até o momento da escrita da presente pesquisa, não fui capaz de encontrar nenhuma informação a respeito das estratégias tradutórias empregadas para lidar com a não-binariedade do gênero dxs personagens em fontes metatextuais, de maneira que essas precisarão ser inferidas 
a partir da análise do componente microtextual. Sendo assim, prosseguirei imediatamente à análise do trecho traduzido abaixo.
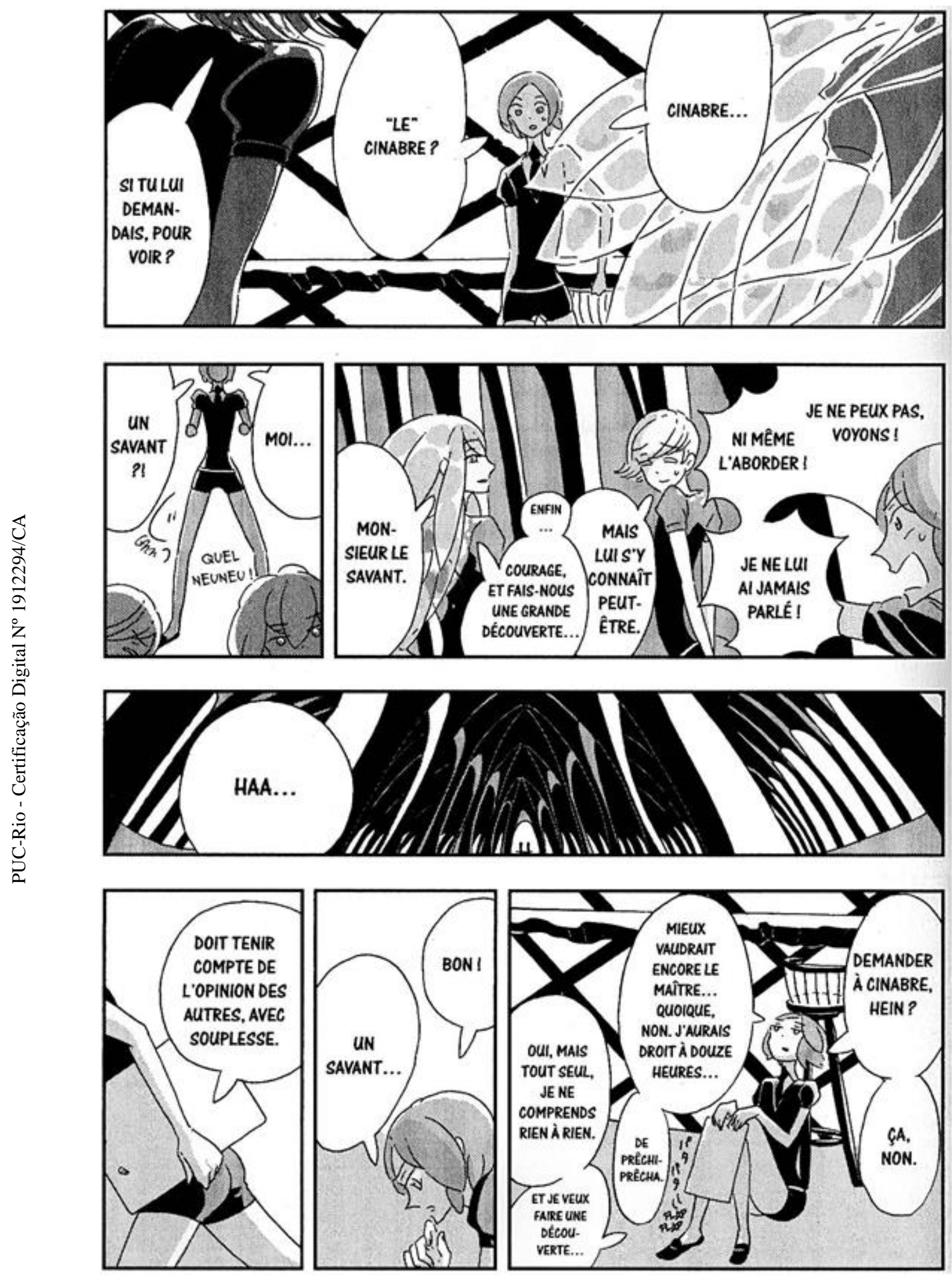

Figura 13: fragmento de cena do capítulo 2 (ICHIKAWA, 2016a, p.41) 
A tradução francesa optou por generificar xs personagens no masculino, conforme pode-se notar a partir das formas adotadas principalmente em relação ax personagem Fosfofilita. Dentre elas, a mais evidente é o uso do pronome de tratamento masculino "monsieur" ("monsieur le savant”), porém, outras formas masculinas também estão presentes, como o substantivo "savant" e o adjetivo "seul" (em oposição às suas formas femininas "savante" e "seule").

Apesar do uso de formas generificadas para se referir axs personagens, uma leitura mais atenta do texto revela que foram empregados alguns recursos neutros de retomada do referente. Por exemplo, o uso do pronome "lui", que é neutro quando ocupa a posição de objeto da oração, nos trechos "Si tu lui demandais, pour voir" e "Je ne lui ai jamais parlé!". O mesmo não se aplica no caso da oração "Mais lui s'y connaît peut-être", na qual ocupa a posição de sujeito, sendo, portanto, masculino. Outro recurso de neutralização do gênero empregado pela tradutora é a contração dos artigos que precedem verbos que se iniciam em vogais. Nesses casos, a língua francesa permite que a vogal que marcaria o gênero dos artigos seja omitida, utilizando-se uma apóstrofe em seu lugar, conforme pode ser visto em "Ni même l'aborder!".

O emprego tanto de formas masculinas quanto de formas neutras para se referir axs personagens parece sugerir que a estratégia utilizada para lidar com a sua não-binariedade de gênero é semelhante à utilizada pela tradução amadora para o espanhol: manter a referência neutra "quando possível" e utilizar o masculino quando impossível.

No entanto, não se pode deixar de notar o uso das aspas no artigo masculino "le" na primeira vinheta. O seu uso chama a atenção a esse artigo ao mesmo tempo em que o coloca em dúvida, como que questionando se o seu emprego é, de fato, apropriado. Com isso, o seu uso coloca em dúvida o caráter masculino do gênero dxs personagens e pode ser caracterizado como uma instância de complementação nos termos de Lewis (2010).

\subsection{Tradução profissional para o inglês}

Assim como a tradução francesa, a tradução norte-americana é publicada em volumes contendo em média 7 capítulos e 200 páginas cada. A capa e a contracapa seguem o mesmo modelo da edição japonesa: com uma ilustração de algumxs dxs 
personagens, o título da obra, o número do volume e o nome da autora logo abaixo em fonte menor. Essas mesmas informações aparecem também na lombada, acompanhadas pelo logotipo da editora. Na contracapa, encontra-se uma sinopse do volume seguida de fragmentos de resenha de sites especializados ${ }^{26}$. Vê-se também uma classificação indicativa que destina o mangá a um público maior de 13 anos abaixo do nome da editora. Nesse ponto, a tradução difere-se do texto fonte e da tradução francesa, que são classificados como seinen, isto é, voltado para um público mais maduro. Os nomes das tradutoras Athena Nibley e Alethea Nibley são creditados na folha do expediente.

Como paratextos, as edições destinam uma ou duas páginas às notas das tradutoras ao final de cada volume. Além disso, a partir do segundo volume, passam a dispor de duas páginas de apresentação dxs personagens, com algumas informações a respeito das suas personalidades; segue-se a isso um sumário.

As tradutoras utilizam o espaço designado às notas para explicar aspectos relacionados à linguagem, às suas escolhas tradutórias, às características das gemas das quais são compostxs xs personagens e elementos da cultura japonesa que podem ajudar a compreender melhor o texto. Esse último é particularmente importante, já que a obra de Ichikawa incorpora muitos elementos da religião budista que passariam despercebidos à maioria dxs leitorxs ocidentais.

Por outro lado, nenhuma das notas nos 10 volumes publicados até o momento fala sobre a forma como as tradutoras resolveram abordar a tradução do aspecto não-binário do gênero dxs personagens, de maneira que, apesar de o terem mantido, uma das formas de visibilizar essa característica da obra sugerida por Lewis não foi aproveitada.

Devido a isso, não é possível aferir as estratégias gerais utilizadas pelas tradutoras para lidar com o gênero dxs personagens a partir de uma análise dos paratextos do volume. Contudo, é possível encontrar algumas poucas informações a respeito dessas estratégias em fontes metatextuais. Em um artigo publicado em 2017, Lauren Scanlan, a editora responsável pela série, fala um pouco sobre a abordagem adotada:

\footnotetext{
${ }^{26}$ Esses fragmentos só passaram a fazer parte das edições a partir do volume 3 e em futuras reimpressões dos dois primeiros volumes. Antes disso, a sinopse era acompanhada dos dizeres " $\mathrm{An}$ elegant new action manga for fans of Steven Universe" - o que também aponta para a intenção da editora norte-americana de direcionar o mangá a um público mais jovem. Essa comparação foi removida devido à repercussão negativa. Além disso, a partir do volume 6, os dizeres "Now a hit anime" também passou a figurar na contracapa após o sucesso da sua adaptação em anime.
} 
Consultamos a autora e a equipe editorial japonesa sobre a série e, no final das contas, a decisão de usar os nomes dxs gemas (ou o uso de "gem" como pronome!) partiu de nós, para manter a clareza na versão em inglês desta história maravilhosa com um grande elenco de personagens que podem ou não estar na tela para o diálogo. (SCANLAN apud KAISER, 2017, s.p., grifo meu)

Percebe-se que, apesar de isso não ser explicitado no volume, houve uma grande preocupação em manter o gênero neutro dxs personagens por parte da tradução. Esse posicionamento adotado aparece de forma sutil em uma das notas das tradutoras na qual explicam a sua decisão de utilizar o apelido "Didi" para traduzir o termo de parentesco "nii-chan":

\section{TRANSLATION NOTES}

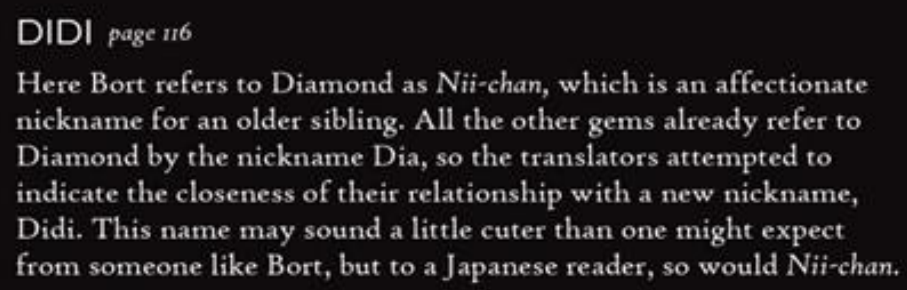

Figura 14: nota das tradutoras (NIBLEY; NIBLEY, 2017, p.196)

Ao explicarem o significado de "nii-chan", as tradutoras fazem uso do termo neutro "sibling", sugerindo, dessa maneira, que o termo japonês é também uma forma neutra de se referir a um irmão ou irmã mais velhx. Contudo, a palavra "nii" é uma palavra masculina e aplica-se apenas a um irmão mais velho, em oposição à palavra "nee", que significa irmã mais velha. É muito pouco provável que as tradutoras desconheçam os sentidos dessas palavras, de forma que o uso de um termo neutro na nota parece ter sido uma escolha deliberada de sua parte para não designar um gênero axs personagens.

Não se pode deixar de notar, todavia, a preocupação que a editora Lauren Scanlan demonstra em "manter a clareza na versão em inglês". Tal cuidado aponta para a escolha de uma estratégia de tradução que privilegia a fluência do texto. Sendo assim, pode-se dizer que a tradução profissional para o inglês procura (1) manter a não-binariedade de gênero dxs personagens de Houseki no kuni (2) comprometendo o mínimo possível a fluência do texto. 
No fragmento abaixo, podemos ver algumas das estratégias adotadas pelas tradutoras para evitar o uso de formas generificadas de referir-se axs personagens.
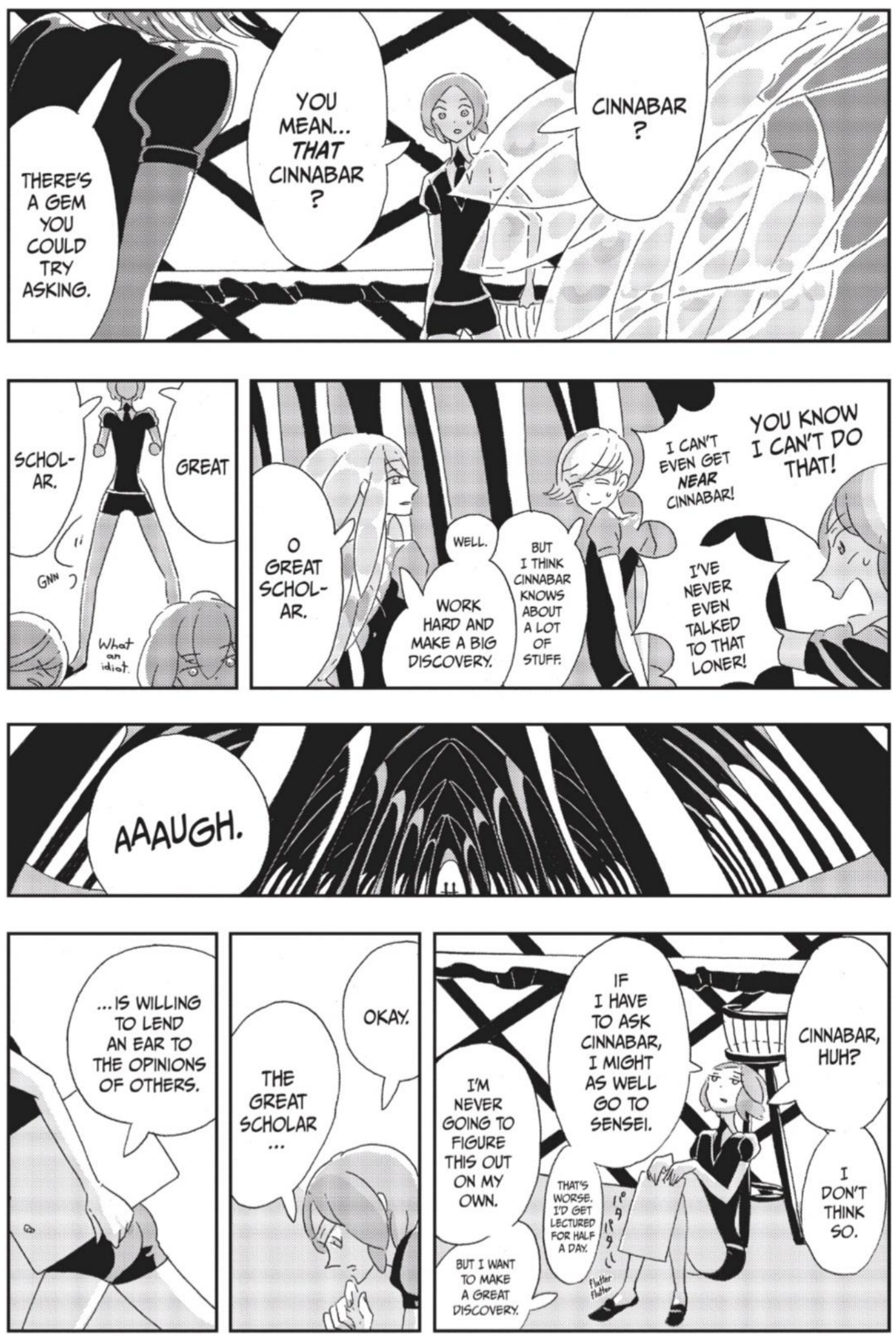

Figura 15: fragmento de cena do capítulo 2 (ICHIKAWA, 2017a, p.41) 
Como se pode perceber, há diferenças notáveis entre as duas traduções para a língua inglesa. Aqui, assim como na tradução em scanlation, o referente "Cinnabar" é introduzido no primeiro balão, porém, as formas de retomá-lo no decorrer da conversa variam. No primeiro quadro, por exemplo, é utilizado a palavra "gem" ("there's a gem you could try asking"), que funciona aqui como um hiperônimo devido ao fato de xs personagens serem compostas por minerais, conforme mencionado anteriormente. Mais adiante, onde na tradução amadora são utilizados os pronomes "him" e "he", aqui são utilizados o próprio nome $\mathrm{dx}$ personagem ("I can't even get near Cinnabar!", "But I think Cinnabar knows about a lot of stuff'); além disso, em uma das instâncias, as tradutoras aproveitamse do fato de Cinnabar isolar-se dxs demais personagens e utilizam-se da expressão nominal "that loner" para retomar o referente ("I've never even talked to that loner!"). Por fim, diferente da tradução em scanlation, em que Morganita utiliza o pronome de tratamento "mister" ao dirigir-se ax Fosfofilita, aqui é utilizado o adjetivo "great" ("o great scholar").

Como se sabe, na língua inglesa o gênero não é uma categoria gramatical que se aplique obrigatoriamente a todo e qualquer substantivo; em vez disso, o seu gênero é majoritariamente semântico e presente apenas em alguns pronomes (he/she, his/hers etc.) e substantivos generificados como sister, father, mother. Isso possibilita que se fale $\mathrm{dxs}$ personagens sem que qualquer referência a qualquer dos gêneros seja feita. Percebe-se aqui que claramente houve uma preocupação em preservar a não-binariedade do gênero por parte das tradutoras. Como foi demonstrado no trecho acima, as tradutoras empregam diversos recursos para evitar que um gênero seja atribuído axs personagens: o uso de pronomes de terceira pessoa do singular é evitado, pois esses possuem gênero; o próprio nome dx personagem é utilizado diversas vezes para retomar o referente; além de recorrerem ao uso de hiperônimos e expressões nominais.

Além desses, em outros trechos do mangá, são utilizados vários outros recursos para manter a referência neutra. Para melhor ilustrá-los, farei uma comparação direta entre alguns trechos da tradução amadora e profissional. Segue abaixo um fragmento retirado da página 7 do segundo capítulo da tradução amadora, no qual se pode notar mais uma vez o reforço constante do masculino para se referir ax personagem Cinnabar, que volta a ser generificadx por meio do 
uso repetido dos pronomes masculinos " $h e$ " e "his", além do substantivo masculino "guy".
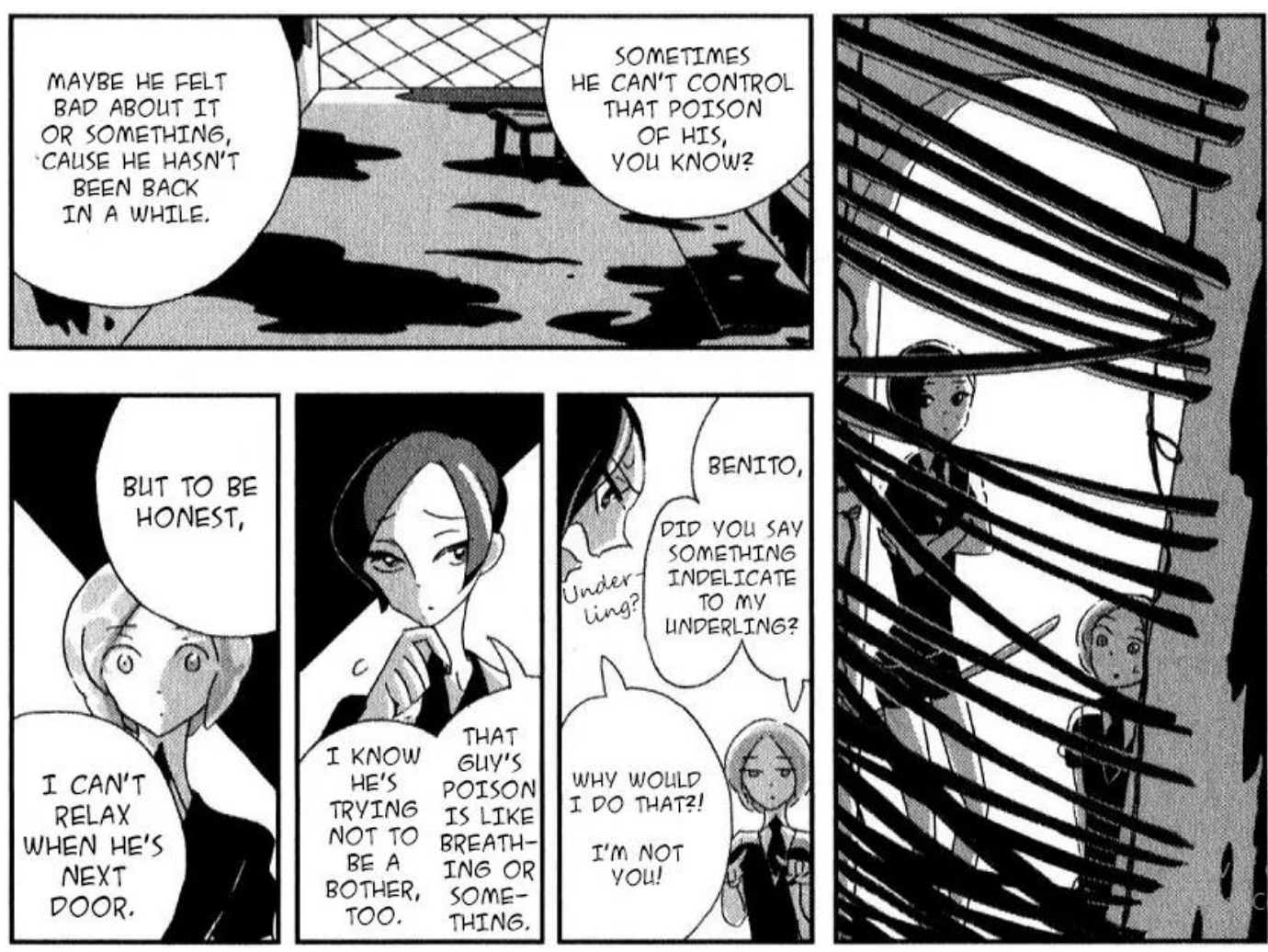

Figura 16: uso do masculino na tradução amadora para o inglês (ICHIKAWA, 2020b, p.7)

O mesmo trecho é abordado de forma bastante distinta na tradução profissional das irmãs Nibley. Conforme pode ser observado no trecho abaixo, são utilizadas inversões no sujeito das orações como forma de não designar um gênero axs personagens. No primeiro balão da segunda vinheta, por exemplo, enquanto na tradução amadora, Cinnabar perdia o controle sobre o veneno ("Sometimes he can't control that poison of his, you know?"), aqui é o veneno que sai do controle ("You know how that venom gets out of control sometimes."). O mesmo recurso é empregado no balão seguinte: onde na tradução amadora, Cinnabar não voltava ao seu quarto havia um tempo (“[...] cause he hasn't been back in a while."), na tradução profissional, o quarto é que tem estado vazio há um longo tempo ("That room's been empty for a long time."). Ademais, na quarta vinheta, "o veneno daquele cara" ("That guy's poison") passa a ser apenas "aquele veneno" (“That venom"). 

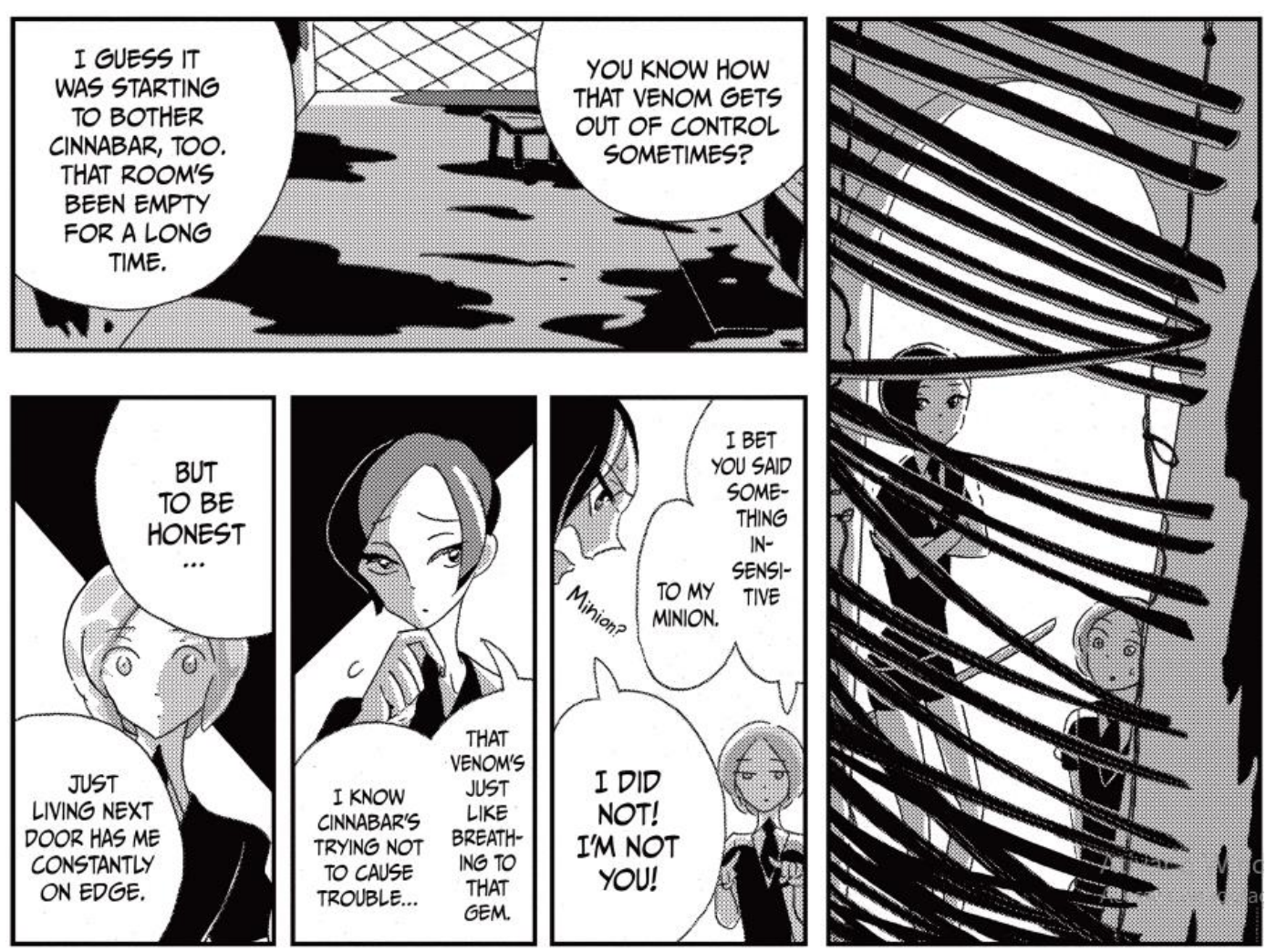

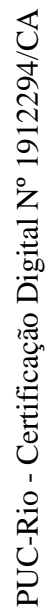
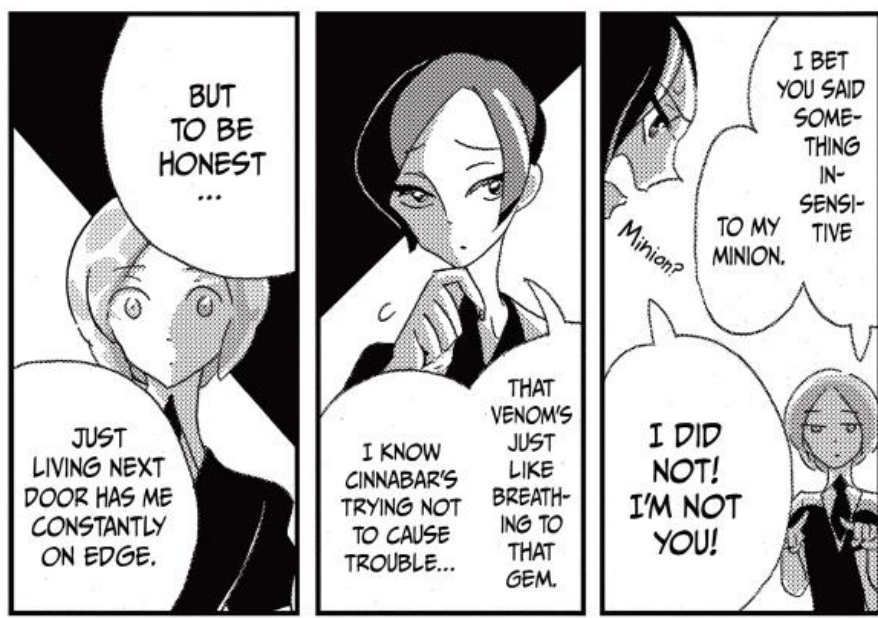

Figura 17: mudança nos sujeitos das orações para evitar o uso do masculino (ICHIKAWA, 2017a, p.45)

Além disso, no trecho abaixo, diferente do que foi feito na tradução amadora (ver seção 3.2.1), o uso dos pronomes masculinos "he", "him" e "his" foi evitado ao fazer com que $\mathrm{x}$ personagem Fosfofilita empregue um discurso impessoal ao comentar a situação na qual Cinnabar encontra-se.
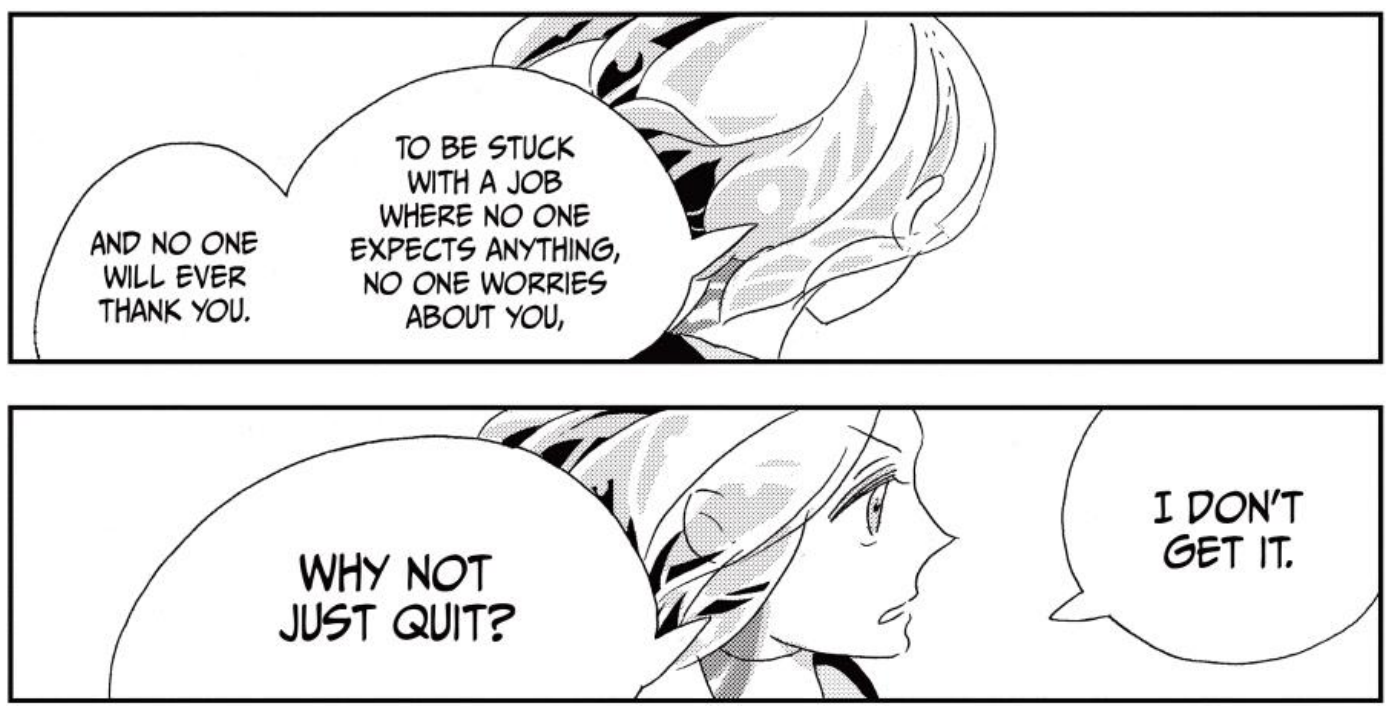

Figura 18: uso do discurso impessoal para evitar formas masculinas (ICHIKAWA, 2017a, p. 46) 
Dessa forma, as tradutoras conseguem preservar a não-binariedade de gênero dxs personagens ao mesmo tempo em que demonstram a possibilidade de mantê-la na língua inglesa sem a necessidade de recorrer ao uso controverso do pronome de terceira pessoa do plural "they" para referir-se a alguém no singular. No entanto, isso só foi possível devido ao emprego de uma estratégia de tradução que privilegiou a fluidez do texto. Como foi discutido no capítulo 2, personagens tendem a ser presumidas cis-heterossexuais até que se prove o contrário. No caso do mangá analisado, xs personagens tendem a ser interpretadas como femininas, como vimos nos comentários retirados de um fórum de discussão na sessão 2.3.2 e nas análises das traduções amadoras para o português e para o espanhol. Dessa forma, apesar de a tradução oficial norte-americana ter sido capaz de manter a não-binariedade de gênero dxs personagens do mangá, não significa que ela foi bem sucedida em evitar o apagamento de suas identidades não-binárias, dado que ela não as visibiliza de nenhuma maneira.

Adotar as táticas de complementação e hijacking da Tradução Queer propostas por Lewis poderia servir para contornar esse problema; contudo, envolveria, também, o sacrifício da fluência do texto, fazendo com que a tradução corresse o risco de não ser bem recebida pelo público leitor. Quanto à tática de escrita de prefácios e notas de tradutorx, uma vez que a língua inglesa permite que se fale de alguém sem fazer referência a um gênero, o seu emprego ao início dos volumes, combinado às estratégias adotadas pelas tradutoras para evitar designar um gênero axs personagens, cumpriria o propósito de visibilizar as identidades não-binárias dxs gemas, pois significaria que x leitorx iria deparar-se com essa informação antes de iniciar a leitura. No entanto, tal oportunidade é desperdiçada, pois, como vimos na análise, os volumes não apresentam prefácios, e as notas de tradução não mencionam a não-binariedade de gênero dxs personagens nem as estratégias utilizadas para lidar com ela. 


\section{Considerações finais}

A proposta da presente pesquisa consistiu em estudar como cinco traduções diferentes do mangá Houseki no kuni - três traduções amadoras: uma para o português, uma para o inglês e uma para o espanhol; e duas traduções profissionais: uma para o francês e uma para o inglês - lidaram com a nãobinariedade do gênero dxs personagens. Para isso, foram analisados tanto os textos traduzidos, em si, quanto paratextos e metatextos sobre essas traduções para averiguar se a não-binariedade foi mantida ou apagada - quais estratégias foram utilizadas para mantê-la; quais as justificativas oferecidas para o seu apagamento e se ideologias cis-heteronormativas, de tradução ou de linguagem desempenharam um papel em tal apagamento - e refletir se apenas manter a nãobinariedade de gênero dxs personagens basta para evitar o apagamento de identidades LGBTQAI+, ou se a tradução pode desempenhar um papel mais decisivo na luta contra a hegemonia cis-heteronormativa.

Ao estudar as traduções do mangá Houseki no kuni a partir de uma perspectiva queer, visávamos contribuir para preencher algumas lacunas nos Estudos da Tradução. Primeiro, pretendíamos nos desviar dos demais trabalhos publicados que se debruçam sobre a tradução de textos nos quais figuram conteúdos LGBTQAI+ - os quais tendem a focar apenas em como esses elementos foram mantidos e/ou apagados - ao focar nas ideologias que orientaram as escolhas tradutórias. Segundo, argumentamos que a tradução não apenas é orientada por tais ideologias, mas também pode exercer um papel em sua reprodução e/ou subversão. Por fim, procuramos preencher outra lacuna nos Estudos da Tradução ao levar adiante a proposta de Lewis (2010) para a consolidação do campo da Tradução Queer, de forma a pensar em uma maneira de traduzir que lide especificamente com a tradução de conteúdos LGBTQAI+.

O presente estudo de caso das traduções do mangá Houseki no Kuni demonstra que personagens não-binárixs tendem a ser generificadxs em suas traduções. Todas as traduções para línguas neolatinas atribuíram um gênero axs personagens, sendo ele o masculino no caso da tradução profissional para o francês e da amadora para o espanhol, e o feminino na tradução amadora para o português. $\mathrm{O}$ apagamento da não-binariedade de gênero dxs personagens deu-se por meio do uso de artigos e pronomes masculinos e femininos, além das 
desinências de gênero nos adjetivos que qualificavam xs gemas; o que aponta para restrições decorrentes do próprio gênero gramatical da língua. De fato, a análise das informações meta e paratextuais disponíveis para as duas últimas traduções revela que as dificuldades impostas pela estrutura das línguas neolatinas exerceram um papel crucial no apagamento da não-binariedade de gênero dxs personagens. Ambas as traduções reconhecem que xs gemas não têm um gênero especificado e manifestam um certo esforço em manter a não-binariedade, porém, conforme sugerem os trechos em que é explicitado que a referência neutra será mantida "quando possível” e o masculino será utilizado quando não for, a língua impôs obstáculos que, na visão dxs tradutorxs, seriam intransponíveis. Devido ao fato de não haver paratextos na edição francesa do mangá, e eu não ter conseguido encontrar informações metatextuais disponíveis, é difícil aferir quais foram as motivações que levaram ao apagamento da não-binariedade de gênero dxs personagens. Entretanto, o emprego de estratégias para manter a referência neutra em determinados pontos por parte da tradutora sugere que houve um certo desejo em não designar um gênero axs personagens; porém, assim como o português e o espanhol, o francês não permite que a não-binariedade seja mantida.

Contudo, xs personagens de Houseki no kuni não foram generificadxs apenas nas traduções para línguas neolatinas; a tradução amadora para a língua inglesa também atribui axs gemas o gênero masculino, primariamente na forma do emprego de pronomes masculinos. Isso sugere que o gênero gramatical não é o único fator que desempenha um papel no apagamento da não-binariedade de gênero nas traduções. De acordo com a análise dos paratextos da tradução, a ideia de "fidelidade" desempenhou um papel determinante no uso de formas masculinas de referir-se axs personagens: a afirmação de que é fácil manter a não-binariedade de gênero na língua japonesa somada ao uso de pronomes e outras formas masculinas pelxs gemas implica que o uso do masculino no texto fonte é uma escolha deliberada de sua autora e, devido a isso, a forma mais "fiel" de traduzir o mangá seria utilizar o masculino genérico.

Dentre as traduções analisadas, apenas a tradução profissional norteamericana não atribuiu um gênero axs personagens. Devido ao fato de o inglês não ter um gênero gramatical, o maior obstáculo à manutenção da não-binariedade de gênero consistia em evitar o uso de pronomes generificados. Para alcançar esse objetivo, as tradutoras tiraram proveito de diversos recursos disponíveis na língua, 
como o uso dos próprios nomes dxs personagens para retomar o referente, de formas remissivas lexicais, hiperônimos e mudanças no sujeito das orações. Além disso, evitou-se a utilização de alguns pronomes masculinos por meio de sua substituição por adjetivos.

As estratégias utilizadas pela tradução profissional norte-americana demonstram que houve um grande esforço por parte dessa para que a nãobinariedade de gênero fosse mantida; o que também aparece na fala da editora da série, Lauren Scanlan. No entanto, sua fala também revela a influência de ideologias sobre tradução: o desejo de "manter a clareza" aponta para o que diz Venuti em relação às maneiras como a qualidade das traduções é avaliada. Se olharmos para as decisões tradutórias no nível microtextual, podemos perceber que as estratégias mencionadas acima visam manter a não-binariedade de gênero dxs personagens sem comprometer, ou comprometendo muito pouco a fluência do texto. Como resultado, a não-binariedade de gênero foi, de fato, mantida, porém, esse aspecto da obra não foi visibilizado de nenhuma maneira. Isso, combinado à influência de ideologias cis-heteronormativas que orientam as maneiras como interpretamos os indivíduos, faz com que os esforços da tradução profissional norte-americana não sejam suficientes para impedir o apagamento das identidades não-binárias dxs gemas, uma vez que se esse aspecto de suas identidades não for devidamente visibilizado, dificilmente elxs serão lidxs como não-binárixs. Por outro lado, dado que a língua inglesa não apresenta um gênero gramatical, o emprego da tática de escrita de prefácios ou notas de tradutorx bastaria para visibilizar a não-binariedade de gênero dxs personagens sem que a fluência do texto seja comprometida.

A influência de ideologias cis-heteronormativas na maneira como xs personagens são interpretadxs podem ser observadas também na análise das traduções amadoras para o espanhol e o português. Conforme visto nos meta e paratextos dessas traduções, devido à sua aparência e personalidades, xs gemas são interpretadxs como femininxs apesar de ser reconhecido que não têm um gênero especificado. Tal leitura enviesada aponta para a nossa tendência de interpretar o gênero e a sexualidade dos indivíduos com base em concepções de masculinidade, feminilidade e heterossexualidade hegemônicas, como se houvesse uma única maneira de performar esses aspectos de nossas identidades. No caso da tradução amadora para o português, essa influência é ainda mais 
evidente, pois, de acordo com a própria tradutora, o feminino foi utilizado para a maioria dxs personagens porque elxs "aparentam ser meninas ou agem como meninas". Com isso, confirma-se o que diz Lewis (2010) em seu artigo, uma vez que se trata de um exemplo claro no qual predisposições cis-heteronormativas contribuíram diretamente para o apagamento de identidades LGBTQAI+ em uma tradução.

A conciliação entre fluência e visibilidade não é possível nas traduções de Houseki no kuni para as línguas neolatinas e outras línguas gramaticalmente generificadas. Devido às maneiras como marcam o gênero, não é possível manter a não-binariedade de gênero $\mathrm{dxs}$ personagens sem que sejam cometidos desvios na norma padrão da língua (exceto no caso daquelas que possuem opções neutras oficialmente reconhecidas). Sendo assim, para não designar um gênero axs gemas na tradução para o português, por exemplo, seria necessário utilizar algum tipo de linguagem inclusiva. No entanto, conforme colocam Borba \& Lopes (2018, p.258), "no português, $[\ldots]$ o masculino é esperado em textos que se referem a um grupo misto de pessoas [...], e qualquer inovação em seu uso (e.g. o X) causa estranhamento e engendra discursos higienistas que visam defender o caráter nãomarcado do masculino". Logo, linguagens do tipo não são bem vistas pelos falantes de português, o que pode explicar a opção pelo uso do masculino genérico pela tradução amadora para o português a partir do capítulo 80 .

Apesar de o uso do masculino genérico ser compreensível, não se pode deixar de considerar as influências de ideologias de linguagem por trás de seus usos cis-heteronormativos. A defesa do masculino genérico faz parte do discurso de especialistas - sejam elxs linguistas ou professorxs de língua portuguesa - no qual é “comum [...] a separação radical entre o linguístico e o social. Defende-se a língua ao colocá-la em uma torre de marfim [...] e apartá-la do que xs usuárixs fazem com ela e pensam sobre ela" (BORBA; LOPES, 2018, p.263). De fato, podemos encontrar argumentos do tipo em diversas gramáticas de língua portuguesa. Peguemos, a título de ilustração, um trecho do livro Gramática Houaiss da Língua Portuguesa, no qual se diz sobre a classe gramatical do gênero:

O excesso de importância tradicionalmente concedida a essa subclasse se explica pela confusão que se faz entre gênero - que é uma categoria linguística - e a noção biológica, portanto extralinguística de sexo. Este equívoco já está resolvido desde os trabalhos pioneiros de Manuel Said Ali (1861 - 1953), mas ainda resta uma 
certa confusão em obras recentes destinadas ao ensino médio. (AZEREDO, 2013, p.158)

Como se pode notar, para o autor, há uma clara distinção entre a categoria gramatical gênero e o sexo biológico - e por extensão, o conceito social de gênero. No entanto, essa suposta distinção é meramente ilusória, já que, nos contextos de fala, espera-se que a concordância de gênero empregada pelo falante esteja de acordo com o gênero que foi designado a elx, ou à pessoa da qual se fala, no nascimento: se foi designado o masculino, deve-se utilizar o gênero masculino em seu discurso; e se foi designado o feminino, deve-se utilizar o feminino. A ausência de uma alternativa de gênero neutro significa que pessoas não-binárias serão incapazes de expressar suas próprias identidades. As implicações disso são graves quando consideramos a relação intrínseca que existe entre linguagem e cultura: se a língua que falamos influencia a forma como vemos o mundo, então a existência de apenas dois gêneros possíveis pela língua torna difícil que os seus indivíduos possam interpretar expressões de gênero que não se enquadram na dicotomia masculino/feminino: é como se pessoas não-binárias não existissem para as línguas neolatinas.

É devido a esse apagamento sofrido por pessoas não-binárias que uma tradução do mangá Houseki no kuni que faça uso de linguagem inclusiva de algum tipo para manter a não-binariedade de gênero dxs personagens poderia ser de extrema relevância. De acordo com Borba \& Lopes (2018, p.259),

[...] o X e outras inovações de gênero gramatical são um tipo de "imundície verbal" que desafia o fonofalogocentrismo, tirando a língua de um lugar de pureza e lhe contaminando com usos mundanos, políticos e éticos. A radicalidade estrutural e social dessas inovações linguísticas nos leva a considerá-las como uma espécie de imundície, pois elas não pretendem limpar a língua, mas sim bagunçá-la, desafiam o purismo linguístico, embaralham os binarismos do nível sistêmico (oralidade/escrita; significado/significante, etc.), contaminam a língua com uma agenda política e assim tiram-na de sua zona asséptica de conforto.

Sendo assim, o seu emprego serviria aos propósitos da Tradução Queer pois garantiria que a não-binariedade de gênero dxs personagens fosse não apenas mantida, mas também visibilizada, ao mesmo tempo em que criticaria o binarismo do gênero gramatical de línguas como as neolatinas. 
O que nos leva ao ponto principal da presente pesquisa: apenas manter a não-binariedade de gênero, sem enfatizá-la em alguma medida, basta para evitar o apagamento de identidades LGBTQAI+?

O mangá Houseki no kuni é particularmente relevante para responder a essa pergunta. Conforme vimos no decorrer da pesquisa, temos uma tendência em presumir que pessoas e personagens se conformem à matriz cis-heteronormativa até que nos seja provado o contrário. Se considerarmos um livro, no qual dependemos de informações exclusivamente verbais para interpretarmos xs personagens, se o gênero de umx delxs não for explicitado (e não der para inferilo com base em seu nome ou outras informações fornecidas no texto), provavelmente a interpretaremos como masculinx, uma vez que a forma tida como "neutra" em línguas gramaticalmente generificadas é o masculino, e pronomes e substantivos neutros em línguas como o inglês tendem a ser interpretados a partir de uma predisposição masculina implícita (PREWITTFREILINO et al., 2012). Todavia, em um texto multimodal como um mangá, além das informações verbais, encontram-se disponíveis também as visuais, de forma que preconcepções de como seriam personagens masculinas e femininas nessa mídia desempenham um papel crucial na maneira como interpretamos o seu gênero. Os resultados dessa predisposição puderam ser observados no decorrer da presente pesquisa. A presunção de que xs personagens eram femininxs com base em suas aparências e personalidades levou ao seu tratamento como femininxs na tradução amadora para o português, e xs únicxs personagens tratadxs no masculino foram xs que apresentam estilizações corporais e traços de personalidade mais comumente associados à masculinidade hegemônica. De maneira semelhante, xs personagens foram interpretadxs como femininxs pelo público devido à sua aparência, sendo essa responsável, também, pela recusa em aceitar que elxs não têm gênero mesmo quando provado o contrário (ver seção 2.3.2). A situação agrava-se quando consideramos que a primeira menção ao fato de xs gemas não terem um gênero ocorre apenas no segundo volume do mangá e torna a aparecer apenas esporadicamente. O fato dessa característica dxs personagens permanecer em segundo plano significa que longos períodos de tempo se passam sem que $\mathrm{x}$ leitorx seja confrontadx com essa informação, contribuindo para que um gênero seja associado a elxs por uma leitura enviesada. 
Conforme mencionado anteriormente, conteúdos LGBTQAI+ podem ser facilmente apagados em traduções. Somando-se a isso o fato de que os indivíduos se encontram inseridos em uma sociedade cis-heteronormativa, e traduções que apenas mantenham esse conteúdo sem visibilizá-lo em alguma medida podem não ser suficientes, dado que, se ele não for apagado pelo texto, o será por uma leitura enviesada. Contudo, traduções do tipo dificilmente seriam bem recebidas pelo público leitor, de maneira que um estudo da sua recepção seria necessário a fim de verificar quais ideologias de tradução ou de linguagem precisam ser desconstruídas para fomentar uma maior aceitação.

A linguagem é um dos mais importantes aspectos do reconhecimento e aceitação de identidades (HORD, 2016).

Examinar como a linguagem, discurso e tópicos queer são traduzidos contribuirá para entender como pessoas que se identificam como queer são marginalizadas através da linguagem e/ou resistem a ela, e como categorias binárias de sexo, gênero e desejo podem se tornar mais fluidas. (LEWIS, 2010, p.20)

Assim, é importante que se encontrem formas de resistir aos usos cisheteronormativos da linguagem, de maneira a criar uma maior representatividade de pessoas LGBTQAI+, e que ideologias cis-heteronormativas presentes na prática tradutória sejam expostas. Espero com esse estudo de caso ter demonstrado que enfatizar os conteúdos LGBTQAI+ de uma obra é uma maneira importante dar a essas pessoas uma maior visibilidade e ajudá-las em sua luta contra o poder subjugador da hegemonia cis-heteronormativa. 


\section{Referências bibliográficas}

ALENCAR, Claudiana Nogueira. Pragmática cultural: uma proposta de pesquisa intervenção nos estudos críticos da linguagem. In: RODRIGUES, Marilia Giselda et al. (orgs). Discurso: sentidos e ação. Franca, SP: Universidade da Franca, 2015. p.141-162. (Coleção Mestrado em Linguística).

ARAGÃO, Sabrina Moura. Scanlation e o poder do leitor-autor na tradução de mangás. TradTerm, São Paulo, vol 27, p. 75-113, Setembro, 2016.

ARANHA, Gláucio. Vozes abafadas: o mangá yaoi como mediação do discurso feminino. Revista Galáxia, São Paulo, n. 19, p. 240-251, jul. 2010.

ASIMAKOULAS, Dimitris. Dude (Looks Like a Lady): Hijacking Transsexual Identity in the Subtitled Version of 'Strella' by Panos Koutras. The Translator 18.1: 42-75. 2012.

AUSTIN, John L. Quando dizer e fazer: palavras e ação. Trad. de Danilo Marcondes. Porto Alegre: Artes Médicas, [1962] 1990.

AZEREDO, José Carlos de. Gramática Houaiss da Língua Portuguesa. São Paulo: Publifolha, 2013.

BAER, Brian James. Translating Queer Texts in Soviet Russia: A Case Study in Productive Censorship. Translation Studies 4.1: 21-40. 2011.

BERLINA, Aleksandra. Homosexuality in the Russian Translation of The Hours. Sexuality and Culture: An Interdisciplinary Quarterly 16:4, 449-466. 2012.

BORBA, Rodrigo; LOPES, Adriana Carvalho. Escrituras de gênero e políticas de différance: imundície verbal e letramentos de intervenção no cotidiano escolar. Linguagem \& Ensino, Pelotas, v.21, n. esp., |VIII SENALE| p.241-285, 2018.

BRENNER, Robin E. Understanding manga, Westport: Libraries Unlimited, 2007.

BUTLER, Judith P. Problemas de gênero: feminismo e subversão da identidade. $12^{\mathrm{a}}$ ed. Traduzido por Renato Aguiar. Rio de Janeiro: Civilização Brasileira, 2016.

CAMP, Margaret. Japanese Lesbian Speech: Sexuality, Gender, Identity, and Language. 2009. 211p. Tese (Doutorado) - University of Arizona, Departament of East Asian Studies, Tucson.

CLOSE, Samantha. "Moon Prism Power!": Censorship as Adaptation in the Case of Sailor Moon. Participations Journal of Audience and Reception Studies, vol 14, n. 1, p. 264-281, Maio, 2017.

CRUZ, Leonardo Dias. \#primeiroassedio: processos de entextualização e categorização em discursos sobre feminismo na web. 2017. 150p. Dissertação 
(Mestrado em Linguística Aplicada) - Departamento de Letras, Universidade Federal do Rio de Janeiro, Rio de Janeiro.

DARLINGTON, Tania; COOPER, Sara. "The Power of Truth: Gender and Sexuality in Manga. In: Toni Johnson-Woods (Ed.) Manga an Antology of Global ans Cultural Perspectives. New York: Continuum, 2010.

DÉPÊCHE, Marie-France. A tradução feminista: Teorias e Práticas subversivas Nísia Floresta e a Escola de Tradução Canadense. TEXTOS DE HISTÓRIA, vol.08, $\mathrm{n}^{\circ} 1 / 2,2000$.

DERRIDA, Jacques. [1972] 1991. "Assinatura, Acontecimento, Contexto". In: DERRIDA, Jacques. [1972] 1991. Limited Inc. Trad. de C. M. Cesar. Campinas: Papirus, p. 11-37.

ECKERT, Kleber. Análise de erros em produções escritas de língua espanhola por alunos do Ensino Médio/Técnico: o caso dos artigos definidos. LínguaTec, Bento Gonçalves, v.2, n.3, p. 1-24, jun. 2017.

FLOTOW, Louise Von. Feminist Translation: Contexts, Practices and Theories. TTR: Traduction, Terminologie, Rédacion, v.4, n.2, 1991. p.69-84.

. Translating Women: from recent histories and re-translations to "Queerying" translation, and metramorphosis. Quaderns. Revista de Traducción 19: 127-139. 2012.

Tracing the Context of Translation: The Exemple of Gender. In: SANTAEMILIA, José (Ed.). Gender, sex and translation: the manipulation of identities. Oxfordshire, New York: Routledge, 2014, p.39-52.

FROTA, Maria Paula. Lawrence Venuti e a teoria da (in)visibilidade do tradutor. In: __ A singularidade na escrita tradutora: linguagem e subjetividade nos estudos da tradução, na linguística e na psicanálise. São Paulo: Pontes, 2000. p. 71-136.

GARRAIO, Júlia; TOLDY, Teresa. "Ideologia de gênero": origem e disseminação de um discurso antifeminista. Mandrágora, v.26, n. 1, 2020, p. 129-155.

GONCALVES, Eliane; PINTO, Joana Plaza. Reflexões e problemas da 'transmissão' intergeracional no feminismo brasileiro. Cadernos Pagu, n. 36, p. 25-46, janeiro-junho, 2011.

GORJANC, Vojko. Encoding Heteronormativity in the Target Culture: Slovenian Translations of The Merchant of Venice. In: Meta 57:1, p.145-158. 2012.

HARVEY, Keith.Translating Camp Talk. Gay Identities and Cultural Transfer. The Translator 4.2: 295-320, 1998. 
HORD, Levi C. R.. Bucking the Linguístic Binary: Gender Neutral Language in English, Swedish, French and German. Western Papers in Linguístics/ Cahiers linguistiques de western: vol. 3, Iss. 1, article 4. 2016.

ICHIKAWA, Haruko. L'ère des Cristaux vol. 1.. Tradução de Anne-Sophie Thévenon. Paris: Editora Glènat, 2016a.

. Houseki no Kuni cap.1. 2016b. Tradução de Venezuela no fansub. Disponível em: <https://es.ninemanga.com/manga/Houseki+no+Kuni.html> . Acesso em: 27/01/2021.

. Houseki no Kuni cap.2. 2016c. Tradução de Venezuela no fansub. Disponível em: <https://es.ninemanga.com/manga/Houseki+no+Kuni.html>. Acesso em: 27/01/2021.

Land of the Lustrous vol. 1. Digital Edition. Tradução de Atena Nibley e Alethea Nibley. San Francisco: Kodansha Comics, 2017a.

Houseki no Kuni cap.2. 2017b. Tradução de Samoro. Disponível em: <https://dispersiontl.blogspot.com/2017/10/houseki-no-kuni-2_18.html>. Acesso em: 27/01/2021.

Houseki no Kuni cap.38. 2018. Tradução de Samoro. Disponível em: <https://dispersiontl.blogspot.com/2018/01/houseki-no-kuni-38.html>. Acesso em: 27/01/2021.

Houseki no Kuni cap.30. 2019. Tradução de syomushroom. Disponível em: <https://manganelo.com/chapter/houseki_no_kuni/chapter_30> . Acesso em: 27/01/2021.

Houseki no Kuni cap.1. 2020a. Disponível em: $\langle$ https://manganelo.com/chapter/houseki_no_kuni/chapter_1 $>$. Acesso em: 27/01/2021.

<https://manganelo.com/chapter/houseki_no_kuni/chapter_2>. Acesso em: 27/01/2021.

Houseki no Kuni cap.83. 2020c. Tradução de Samoro. Disponível em: <https://dispersiontl.blogspot.com/2020/01/nos-nao-paramos-houseki-nokuni-83-84.html>. Acesso em: 27/01/2021.

JÜNGST, Heike Elizabeth. Translating Manga. In: ZANETTIN, Federico (Ed). Comics in Translation. Londres e Nova York: Routledge, 2014. p. 50 - 78.

KAISER, Vrai. [Feature] Land of the Lustrous, singular "they", and the politics of subtitles. Anime Feminist. 15 dez. 2017a. Disponível em: https://www.animefeminist.com/feature-land-lustrous-singular-politics-subtitles/. Acesso em: 15/10/2020. 
Land of the Lustrous is much more than "anime Steven Universe".

The Mary Sue. 13 nov. 2017b. Disponível em: https://www.themarysue.com/landof-the-lustrous/, acesso em 07/12/2019.

LAMBERT, José; VAN GORP, Hendrik. Sobre a descrição de traduções. Trad. Marie Hélène Catherine Torres e Lincoln Fernandes. In: GUERINI, Andrea et al. (Orgs.) Literatura e Tradução. Textos selecionados de José Lambert. Rio de Janeiro: 7Letras, 2011.p. 197-220.

LAU, Heliton. Pensando fora do cistema: uma reflexão sobre linguagem não binária. Uniletras, vol.41, n.1, p.262-282, 2019.

LEFEVERE, André. Translation, Rewriting and the Manipulation of Literary Fame. Lon-don/New York: Routledge, 1992.

LEFEVERE, André; BASSNETT, Susan. Introduction: Proust's Grandmother and the Thousand and One Nights: The 'Cultural Turn' in Translation Studies. In: BASSNETT, Susan; LEFEVERE, André (Eds.). Translation, History and Culture. London/NY: Pinter, 1990, p. 1-13.

LEUNG, Matthew Wing-Kwong. The Ideological Turn in Translation Studies. In: DUARTE, João Ferreira et al. Translation Studies at the Interface of Disciplines. Amsterdam: John Benjamins, 2006. p. 129-144.

LEWIS, Elizabeth Sara. "This is My Girlfriend Linda" Translating Queer Relationships in Film: A Case Study of Subtitles for Gia and a Proposal for Developing the Field of Queer Translation Studies". The journal for Literary Translators, Inverno, n. 36, 2010.

"Não é uma fase": construções identitárias em narrativas de ativistas LGBT que se identificam como bissexuais. 2012. 267p. Dissertação (Mestrado em Letras/Estudos da Linguagem) - Departamento de Letras, Pontifícia Universidade Católica do Rio de Janeiro, Rio de Janeiro.

. "Acho que isso foi bastante macho pra ela": reforço e subversão de ideologias heteronormativas em performances narrativas digitais de praticantes de pegging. 2016. 333p. Tese (Doutorado em Letras/Estudos da Linguagem) - Pontifícia Universidade Católica do Rio de Janeiro, Departamento de Letras.

Teoria(s) Queer e performatividade: mudança social na matriz heteronormativa. In: MACEDO, Elizabeth Fernandes de; RANNIERY, Thiago Moreira de Oliveira (orgs). Sexualidade e Educação: pensando a ação docente. Petrópolis, RJ: Editora DP et alii, 2017, p. 157-186.

LINDER, Daniel. Getting Away with Murder: The Maltese Falcon's Specialized Homosexual Slang Gunned Down in Translation. Target 26:3, p.337-36, 2014. 
MARTINS, Marcia A. P. As contribuições de André Lefevere e Lawrence Venuti para a teoria da tradução. Cadernos de Letras (UFRJ), v.27, p.59 - 72, 2010.

McLLELAND, Mark. The "Beautiful Boy" in Japanese Girl's Manga In: JOHNSON-WOODS, Toni (Ed.) Manga an Antology of Global and Cultural Perspectives. New York: Continuum, 2010.

MIYAZAKI, Ayumi. Japanese junior high school girls' and boys' first-person pronoun use and their social world. In S. Okamoto \& J.S. Shibamoto Smith (eds.), Japanese language, gender, and ideology: cultural models and real people (pp. 256-274). Oxford: Oxford University Press, 2004.

NIBLEY, Athena; NIBLEY, Alethea. Translation notes. In: ICHIKAWA, Haruko. Land of the Lustrous vol. 4. Digital Edition Tradução de Atena Nibley e Alethea Nibley. San Francisco: Kodansha Comics, 2017. p.196.

PREWITT-FREILINO, Jennifer L.; CASWELL, T. Andrew; LAAKSO, Emmi K. The Gendering of Language: A Comparison of Gender Equality in Countries with Gendered, Natural Gender, and Genderless Languages. Sex Roles, 66, 268-281, 2012.

PADILHA, Vitória Braga; PALMA, Yáskara Arrial. Vivências não-binárias na contemporaneidade: um rompimento com o binarismo de gênero. In: SEMINÁRIO INTERNACIONAL FAZENDO O GÊNERO 11 \& 13th WOMEN'S WORLD CONGRESS. Anais eletrônicos... Florianópolis: 2017. p. 1-10.

RANZATO, Irene. Gayspeak and Gay Subjects in Audiovisual Translation Strategies in Italian Dubbing”. In Meta 57: 2, p.369-384, 2012.

SALIH, Sara. Judith Butler e a Teoria Queer. Tradução e notas Guacira Lopes Louro. $-1^{a}$ ed.; 2 reimp. - Belo Horizonte: Autentica Editora, 2015.

SAMORO. Houseki no Kuni \#2. Dispersion translations. 18 out. 2017. Disponível em: <https://dispersiontl.blogspot.com/2017/10/houseki-no-kuni-2_18.html>. Acesso em: 26/01/2021.

Houseki no kuni \#39 a \#42. Dispersion translations 18 jan. 2018.

Disponível em: <https://dispersiontl.blogspot.com/2018/01/houseki-no-kuni-3942.html>. Acesso em: 26/01/2021.

$\begin{array}{lrrrlr} & \text { Avisos e } & \text { Alterações } & \text { Sobre Houseki no Kuni. Dispersion } \\ \text { translations. } & 25 & \text { jul. } & 2019 . & \text { Disponível } & \text { em: }\end{array}$ https://dispersiontl.blogspot.com/2019/07/avisos-e-alteracoes-sobre-housekino.html. Acesso em: 26/01/2021.

Nota da tradutora. In: ICHIKAWA, Haruko. Houseki no kuni.

Tradução de Samoro. 2019b. Disponível em: https://dispersiontl.blogspot.com/2019/08/houseki-no-kuni-80-otome-game-6-ecombo.html. Acesso em: 08/02/2021. 
SANTAEMILIA, José. The Translaton of Sex-Related Language: The Danger(s) of Self-Censorship(s). TRR: Tradución Terminologie Rédaction, v. XXI, n.2, p.221-251, 2008.

SCHÄFFER, Ana Maria de Moura. Representações de tradução de gênero no dizer de tradutoras brasileiras / Ana Maria de Moura Schäffer. 2010. 260p. Tese (doutorado) - Universidade Estadual de Campinas, Instituto de Estudos da Linguagem.

TOURY, Gideon. Descriptive TranslationStudies and Beyond. Amsterdam: John Benja-mins, 1995.

TYMOCZKO, Maria. Ideology and the Position of the Translator In What Sense is a Translator "In Between"? In: PÉREZ, María Calzada (ed.). Apropos of ideology: trnaslation studies on ideology, ideology in translation studies. Oxfordshire, New York: Routledge, 2014. p.181-201.

TYULENEV, Sergey. Strategies of Translating Sexualities as Part of the Secularization of Eighteenth- and Early Nineteenth-century Russia. Comparative Literature Studies 51.2 (2014): p.253-276, 2014.

VALDÉON, Roberto A. Schemata, scripts and the gay issue in contemporary dubbed sitcoms. Target 22:1, p.71-93, 2010.

VENUTI, Lawrence. The Translator's Invisibility: A History of Translation. London/New York: Routledge, 2008.

Escândalos da Tradução: por uma ética da diferença. Traduzido por Laureano Pelegrin, Lucinélia Marcelino Villela, Marileide Dias Esqueda, Valéria Biondo; revisão técnica Stella Tagnin. São Paulo: Editora Unesp, 2019.

VILLANUEVA, Michelle. The audacious queerness of Land of the Lustrous. Syfywire. 2018. Disponível em: https://www.syfy.com/syfywire/the-audaciousqueerness-of-land-of-the-lustrous. Acesso em: 07/12/2019.

ZOBERMAN, Pierre. "Homme" Peut-il Vouloir Dire "Femme"? Gender and Translation in Seventeenth-century French Moral Literature. Comparative Literature Studies 51.2 (2014): p.231-252, 2014. 